\title{
Engineering Evaluation/Cost Analysis for the Proposed Removal Action at the Southeast Drainage near the Weldon Spring Site, Weldon Spring, Missouri
}

\section{August 1996}

\author{
prepared by \\ Environmental Assessment Division, Argonne National Laboratory
}

\section{prepared for}

U.S. Department of Energy, Weldon Spring Site Remedial Action Project, Weldon Spring, Missouri, under Contract W-31-109-Eng-38 
बry

This report is printed on recycled paper. 


\section{DISCLAIMER}

Portions of this document may be illegible in electronic image products. Images are produced from the best available original document. 



\section{DISCLAIMER}

This report was prepared as an account of work sponsored by an agency of the United States Government. Neither the United States Government nor any agency thereof, nor any of their employees, makes any warranty, express or implied, or assumes any legal liability or responsibility for the accuracy, completeness, or usefulness of any information, apparatus, product, or process disclosed, or represents that its use would not infringe privately owned rights. Reference herein to any specific commercial product, process, or service by trade name, trademark, manufacturer, or otherwise does not necessarily constitute or imply its endorsement, recommendation, or favoring by the United States Government or any agency thereof. The views and opinions of authors expressed herein do not necessarily state or reflect those of the United States Government or any agency thereof. 



\section{CONTENTS}

NOTATION $\ldots \ldots \ldots \ldots \ldots \ldots \ldots \ldots \ldots \ldots \ldots \ldots \ldots \ldots \ldots \ldots \ldots \ldots \ldots \ldots \ldots \ldots$

1 OVERVIEW AND SUMMARY $\ldots \ldots \ldots \ldots \ldots \ldots \ldots \ldots \ldots \ldots \ldots \ldots \ldots \ldots$

2 SITE CHARACTERIZATION $\ldots \ldots \ldots \ldots \ldots \ldots \ldots \ldots \ldots \ldots \ldots \ldots \ldots$

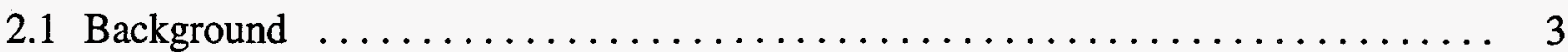

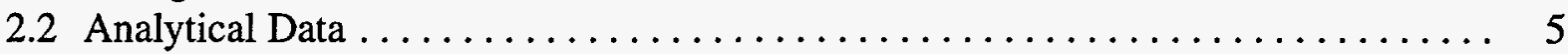

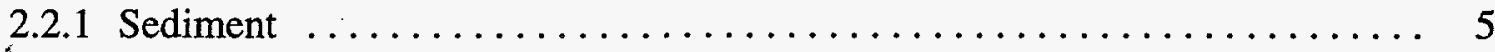

2.2 .2 Surface Water . . . . . . . . . . . . . . . . . . . . . . . . . . . 10

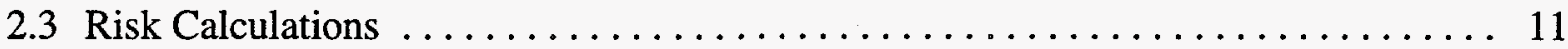

2.3.1 Exposure Assessment and Risk Characterization ................ 14

2.3.2 Human Health Risks from Exposure to Sediment $\ldots \ldots \ldots \ldots \ldots \ldots \ldots$

2.3.3 Human Health Risks from Exposure to Surface Water $\ldots \ldots \ldots \ldots \ldots \ldots 17$

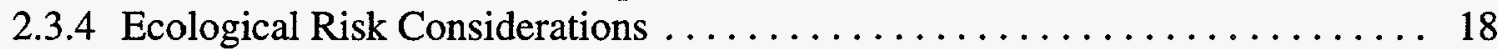

2.3 .5 Summary $\ldots \ldots \ldots \ldots \ldots \ldots \ldots \ldots \ldots \ldots \ldots \ldots \ldots \ldots \ldots \ldots \ldots \ldots \ldots, 24$

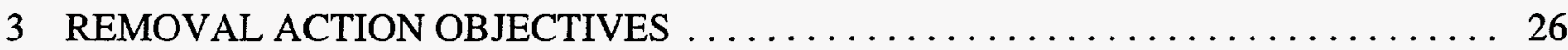

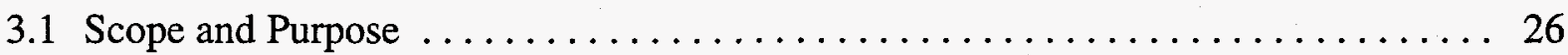

3.2 Compliance with Regulatory Requirements .................... 26

4 IDENTIFICATION OF REMOVAL ACTION ALTERNATIVES $\ldots \ldots \ldots \ldots \ldots \ldots 28$

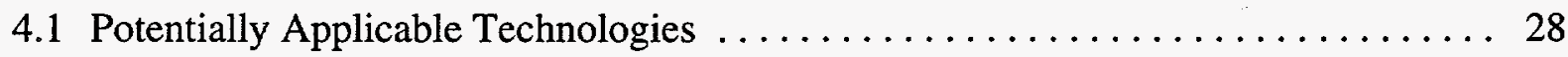

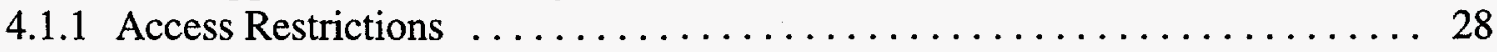

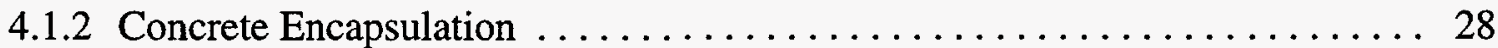

4.1 .3 Hydraulic Removal ................................... 29

4.1.4 Conventional Excavation ........................... 29

4.2 Identification of Preliminary Removal Action Alternatives $\ldots \ldots \ldots \ldots \ldots \ldots$

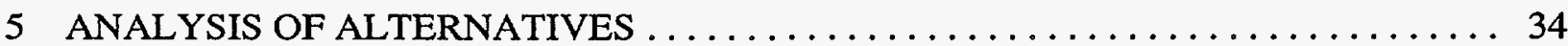

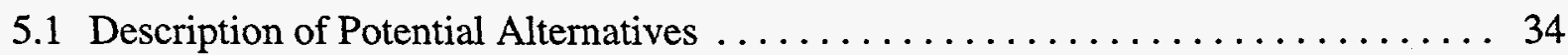

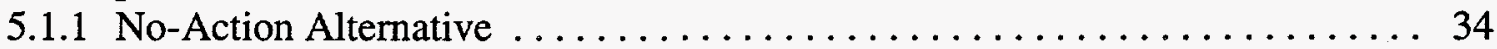

5.1 .2 Alternative 2: Conventional Excavation $\ldots \ldots \ldots \ldots \ldots \ldots \ldots \ldots \ldots \ldots$

5.2 Comparative Analysis of Removal Alternatives $\ldots \ldots \ldots \ldots \ldots \ldots \ldots \ldots$

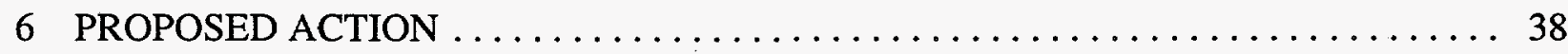

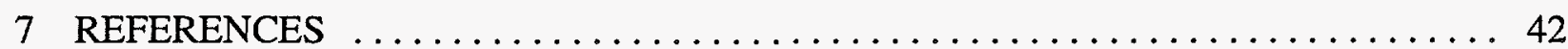




\section{CONTENTS (Cont.)}

APPENDIX A: Location-Specific Risk Calculations for Radioactive Contaminants $\ldots \ldots \quad 47$

APPENDIX B: Contaminant Uptake Modeling for Terrestrial Wildlife $\ldots \ldots \ldots \ldots \ldots .59$

APPENDIX C: Potential Regulatory Requirements for the Southeast Drainage $\ldots \ldots \ldots \ldots 69$

\section{TABLES}

1 Summary of Sediment Data in the Southeast Drainage $\ldots \ldots \ldots \ldots \ldots \ldots \ldots$

2 Summary of Surface Water Data in the Southeast Drainage $\ldots \ldots \ldots \ldots \ldots \ldots . \ldots . \ldots$

3 Exposure Scenario Assumptions and Intake Parameters $\ldots \ldots \ldots \ldots \ldots \ldots \ldots$

4 Estimated Radiological Risks from Exposure to Sediment $\ldots \ldots \ldots \ldots \ldots \ldots \ldots$

5 Estimated Chemical Carcinogenic Risks and Hazard Indexes

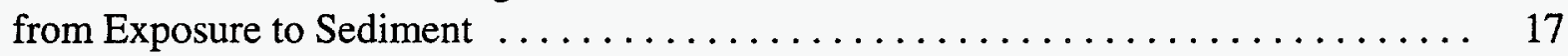

6 Estimated Radiological and Chemical Carcinogenic Risks and Hazard Indexes from Ingestion of Surface Water $\ldots \ldots \ldots \ldots \ldots \ldots \ldots . .18$

7 Estimated Ecological Effects Quotients for Exposure of Aquatic Biota to Surface Water in the Southeast Drainage . . . . . . . . . . . . . . . . . . . 19

8 Results of Acute and Chronic Toxicity Testing of Surface Water from the Southeast Drainage and Background 5400 Drainage $\ldots \ldots \ldots \ldots \ldots . .20$

9 Estimated Ecological Effects Quotients for Exposure of Aquatic Biota

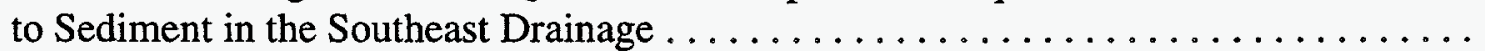

10 Estimated Ecological Effects Quotients from the Water Ingestion Pathway for the White-Tailed Deer, White-Footed Mouse, and Great Horned Owl

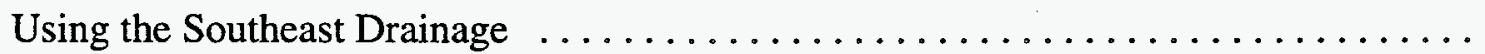

11 Comparative Analysis of Removal Action Alternatives $\ldots \ldots \ldots \ldots \ldots \ldots \ldots$ 


\section{TABLES (Cont.)}

A.1 Dose Conversion Factors and Area Factors for the External Gamma Irradiation and Ingestion Pathways $\ldots \ldots \ldots \ldots \ldots \ldots \ldots \ldots \ldots \ldots \ldots \ldots \ldots \ldots \ldots \ldots$

A.2 Location-Specific Calculations for the Hypothetical Future Child Scenario . ....... 52

A.3 Radiological Risk Reduction Calculations for the Current Hunter $\ldots \ldots \ldots \ldots \ldots 57$

A.4 Radiological Risk Reduction Calculations for the Hypothetical Future Child . . . . . . 57

B.1 Exposure Factors for the White-Tailed Deer $\ldots \ldots \ldots \ldots \ldots \ldots \ldots \ldots \ldots \ldots, 62$

B.2 Exposure Factors for the White-Footed Mouse $\ldots \ldots \ldots \ldots \ldots \ldots \ldots \ldots \ldots \ldots$

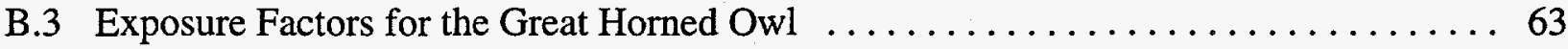

B.4 Estimated Applied Daily Dose for the White-Tailed Deer, White-Footed Mouse, and Great Horned Owl Using the Southeast Drainage .............. 65

B.5 Benchmark Values for NOAEL Doses Used to Estimate Risks

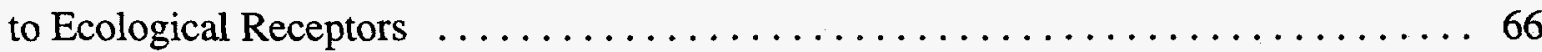

C.1 Potentially Applicable or Relevant and Appropriate Requirements and To-Be-Considered Requirements for the Southeast Drainage Area ............. 71

\section{FIGURES}

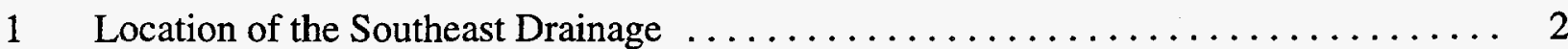

2 Sediment Sampling Locations and Segmentation of the Southeast Drainage $\ldots \ldots \ldots 6$

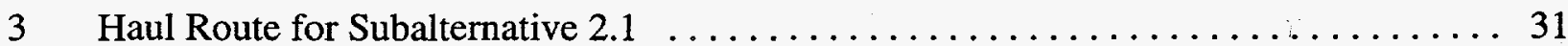

$4 \quad$ Haul Route for Subalternative $2.2 \ldots \ldots \ldots \ldots \ldots \ldots \ldots \ldots \ldots \ldots \ldots \ldots \ldots \ldots \ldots \ldots$

$5 \quad$ Locations Targeted for Remediation under the Proposed Action .............. 39 


\section{NOTATION}

The following is a list of the acronyms, initialisms, and abbreviations (including units of measure) used in this document. Some acronyms used in tables or equations only are defined in the respective tables or equations.

\section{ACRONYMS, INITIALISMS, AND ABBREVIATIONS}

$\begin{array}{ll}\text { ADD } & \text { applied daily dose } \\ \text { AEC } & \text { U.S. Atomic Energy Commission } \\ \text { ARAR } & \begin{array}{l}\text { applicable or relevant and appropriate requirement } \\ \text { ambient water quality criteria }\end{array} \\ \text { AWQC } & \begin{array}{l}\text { Baseline Assessment of the Chemical Plant Area of the Weldon Spring Site } \\ \text { BAOE/ER/21548-091) }\end{array} \\ & \begin{array}{l}\text { Comprehensive Environmental Response, Compensation, and Liability } \\ \text { CERCLA }\end{array} \\ & \text { Act of 1980, as amended } \\ \text { CFR } & \text { Code of Federal Regulations } \\ \text { CSR } & \text { Code of State Regulations } \\ \text { DNT } & \text { dinitrotoluene } \\ \text { DOE } & \text { U.S. Department of Energy } \\ \text { EE/CA } & \text { engineering evaluation/cost analysis } \\ \text { EEQ } & \text { ecological effects quotient } \\ \text { EPA } & \text { U.S. Environmental Protection Agency } \\ \text { FR } & \text { Federal Register } \\ \text { NCP } & \text { National Oil and Hazardous Substances Pollution Contingency Plan } \\ \text { NEPA } & \text { National Environmental Policy Act of 1969, as amended } \\ \text { NOAA } & \text { National Oceanic and Atmospheric Administration } \\ \text { ORAU } & \text { Oak Ridge Associated Universities } \\ \text { PCB } & \text { polychlorinated biphenyl } \\ \text { RI/FS } & \text { remedial investigation/feasibility study } \\ \text { TBC } & \text { to-be-considered (requirement) } \\ \text { TNT } & \text { trinitrotoluene } \\ \text { UCL } & \text { one-tailed 95\% upper confidence limit of the arithmetic average } \\ \text { USC } & \text { United States Code }\end{array}$

\section{UNITS OF MEASURE}

$\begin{array}{ll}{ }^{\circ} \mathrm{C} & \text { degree(s) Celsius } \\ { }^{\circ} \mathrm{F} & \text { degree(s) Fahrenheit } \\ \mathrm{cm} & \text { centimeter(s) } \\ \mathrm{d} & \text { day(s) }\end{array}$

$\begin{array}{ll}\mathrm{dBA} & \text { decibel(s), A-weighted } \\ \mathrm{ft} & \text { foot (feet) } \\ \mathrm{ft}^{2} & \text { square foot (feet) } \\ \mathrm{g} & \text { gram(s) }\end{array}$




$\begin{array}{ll}\mathrm{h} & \text { hour(s) } \\ \text { ha } & \text { hectare(s) } \\ \text { in. } & \text { inch(es) } \\ \mathrm{kg} & \text { kilogram(s) } \\ \mathrm{km} & \text { kilometer(s) } \\ \mathrm{L} & \text { liter(s) } \\ \mu \mathrm{Ci} & \text { microcurie(s) } \\ \mu \mathrm{g} & \text { microgram(s) } \\ \mathrm{m} & \text { meter(s) } \\ \mathrm{m}^{2} & \text { square meter(s) } \\ \mathrm{m}^{3} & \text { cubic meter(s) }\end{array}$

$\begin{array}{ll}\mathrm{mg} & \text { milligram(s) } \\ \mathrm{mi} & \text { mile(s) } \\ \mathrm{mL} & \text { milliliter(s) } \\ \mathrm{mrem} & \text { millirem(s) } \\ \mathrm{pCi} & \text { picocurie(s) } \\ \mathrm{ppm} & \text { part(s) per million } \\ \mathrm{rad} & \text { radiation-absorbed dose } \\ \mathrm{rem} & \text { roentgen-equivalent man } \\ \mathrm{s} & \text { second(s) } \\ \mathrm{yd}^{3} & \text { cubic yard(s) } \\ \mathrm{yr}^{3} & \text { year(s) }\end{array}$





\section{ENGINEERING EVALUATION/COST ANALYSIS FOR THE PROPOSED REMOVAL ACTION AT THE SOUTHEAST DRAINAGE NEAR THE WELDON SPRING SITE, WELDON SPRING, MISSOURI}

\section{OVERVIEW AND SUMMARY}

This engineering evaluation/cost analysis (EE/CA) has been prepared to support the proposed removal of contaminated sediment from selected portions of the Southeast Drainage as part of cleanup activities being conducted at the Weldon Spring site in St. Charles County, Missouri, by the U.S. Department of Energy (DOE). The cleanup activities are conducted in accordance with the Comprehensive Environmental Response, Compensation, and Liability Act (CERCLA), as amended, incorporating the values of the National Environmental Policy Act (NEPA). The Weldon Spring site is located near the town of Weldon Spring, about $48 \mathrm{~km}$ (30 mi) west of St. Louis. It consists of two noncontiguous areas: the chemical plant area and a limestone quarry about $6.4 \mathrm{~km} \mathrm{(4} \mathrm{mi)} \mathrm{south-}$ southwest of the chemical plant area. The Southeast Drainage is a natural 2.4-km (1.5-mi) channel that carries surface runoff to the Missouri River from the southern portion of the chemical plant area and a small portion of the ordnance works area (part of the Weldon Spring Training Area; see Figure 1) south of the groundwater divide. The drainage became contaminated as a result of past activities of the U.S. Army and the DOE (and its predecessors).

For planning purposes, the drainage was delineated into four segments to facilitate the decision-making process. Factors considered in delineating the drainage included accessibility by standard excavation and hauling equipment, main channel slope, side slope, channel width, vegetation characteristics, safety, and public access. Sediment data were collected from each segment, and the results indicate widespread, heterogeneous contamination. Surface water in the drainage is also radioactively and chemically contaminated; the principal contaminant is uranium. Groundwater contamination beneath the drainage is being addressed as part of the remedial investigation/feasibility study (RI/FS) process for the groundwater operable unit of the chemical plant area (DOE 1995b).

Risk calculations performed indicate that on the basis of current and hypothetical future land use, contamination in the drainage does not pose an unacceptable risk to human health and does not indicate a need for further action. However, radioactive contamination in sediment is distributed heterogeneously, and excavation of selected localized areas would provide further protection to a receptor in the drainage. Therefore, the intent of the proposed removal action is to reduce the potential for risk to human health and the environment from contaminated sediment present in the drainage. The excavated material would be transported to and stored in an on-site storage area (e.g., the Ash Pond storage area or the material staging area of the chemical plant), pending final disposition of these materials into the disposal cell. 


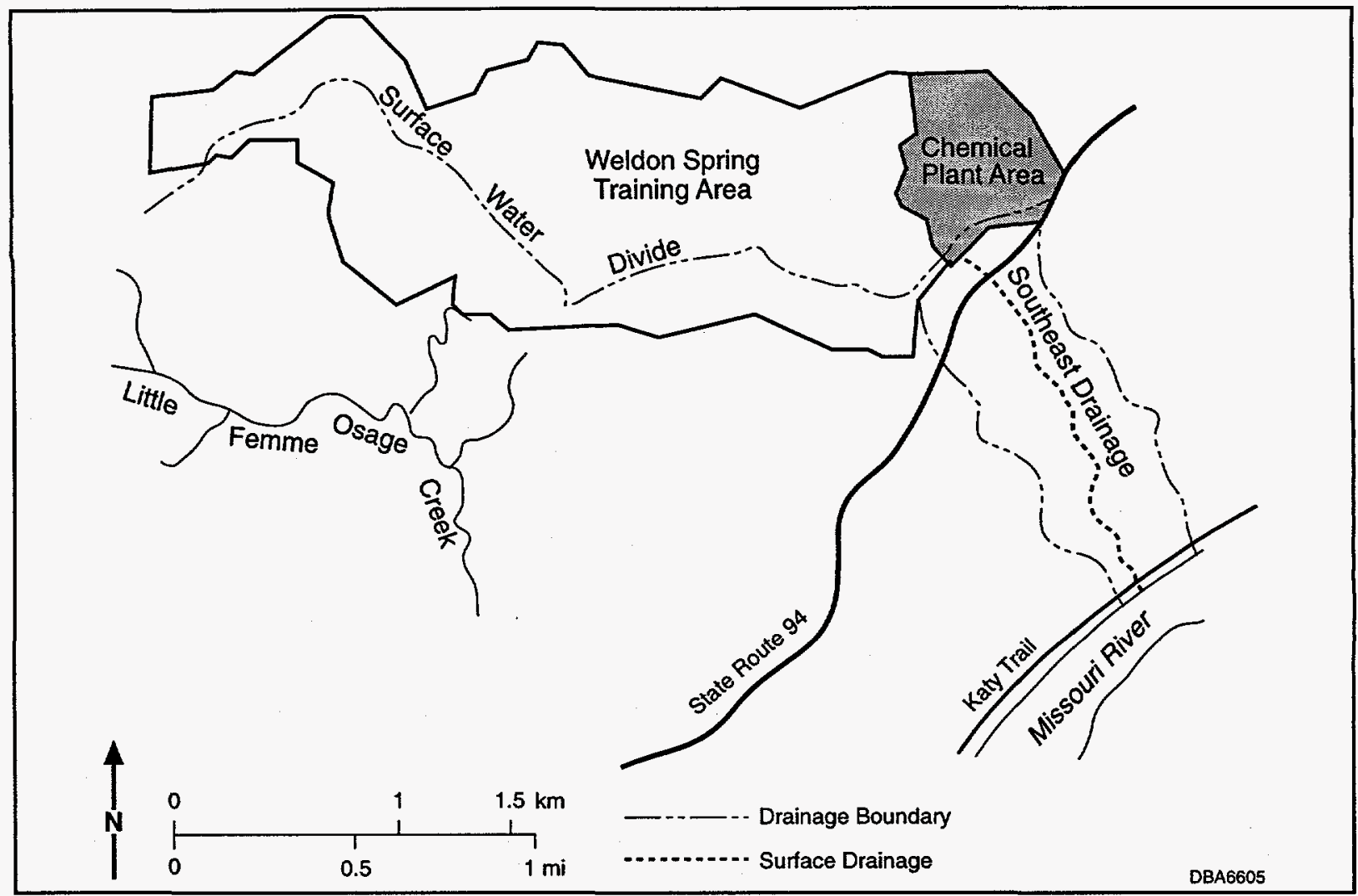

FIGURE 1 Location of the Southeast Drainage

The proposed removal action is expected to be implemented after appropriate regulatory agencies, local governmental officials, and the public have had sufficient opportunity to review and comment on the proposal. The DOE has had preliminary discussions regarding the proposed action with the U.S. Environmental Protection Agency (EPA) Region VII, the Missouri Department of Natural Resources, the Missouri Department of Conservation, the Missouri Department of Health, and the U.S. Army Corps of Engineers. Negotiations and agreements to date are reflected in the discussions presented in this report.

The remaining discussions presented in this report are organized as follows:

- Chapter 2 - A brief site description and background, data summaries, and risk calculations;

- Chapter 3 - Regulatory requirements;

- Chapter 4 - List of potentially applicable technologies and alternatives;

- Chapter 5-Comparison of the potential alternatives; and

- Chapter 6-Description of the proposed removal action. 


\section{SITE CHARACTERIZATION}

\subsection{BACKGROUND}

The Southeast Drainage is a natural, first-order intermittent stream located in a relatively steep-sided valley cut into the limestone bluffs along the Missouri River; the drainage extends from the southeastern corner of the chemical plant area to the river (Figure 1). Historically, the drainage was used by the Army and the U.S. Atomic Energy Commission (AEC, predecessor of DOE) for discharging wastewaters to the Missouri River. The Army operated the Weldon Spring Ordnance Works, an explosives production facility that manufactured trinitrotoluene (TNT) and dinitrotoluene (DNT) in the 1940s for use during World War II. Effluents from the wastewater treatment plants were discharged via the Southeast Drainage. The Weldon Spring chemical plant was operated for the AEC by the Uranium Division of Mallinckrodt Chemical Works from 1957 to 1966 to process uranium ore concentrates. Waste slurries were piped to the raffinate pits, where the solids settled to the bottom; the supernatant liquids were decanted to the plant process sewer, which discharged to the Southeast Drainage. More recently, the drainage was also used to discharge effluents from the sanitary treatment plant at the DOE project office building. As a result of past operations, surface water and sediment in the drainage are radioactively and chemically contaminated. Therefore, the Southeast Drainage has been designated as a chemical plant area vicinity property, for which DOE has responsibility for remediation.

The Southeast Drainage is within the extreme southeastern portion of the Dissected Till Plains, a subdivision of the Central Lowlands Plateau Physiographic Province. The drainage is part of the Missouri River watershed and drains the southern portion of the chemical plant area and a small portion of the ordnance works area south of a groundwater divide that separates the Mississippi and Missouri River watersheds (Figure 1). The total area of the Southeast Drainage basin is about 106 ha (262 acres). Sediment in the drainage consists primarily of silty clays and clayey silts. The upper portion of the channel is situated in a steep, narrow-walled valley where the near surface is rocky with very little sediment. The lower portion flattens and broadens, and sediment deposits increase as the Missouri River is approached. In previous investigations, four springs and one sinkhole were identified in the drainage (Missouri Department of Natural Resources 1991). Although surface water within the channel loses to the subsurface and at times disappears completely, groundwater discharges to the surface within the same channel downstream and is eventually released to the Missouri River; no water losses to areas outside the watershed have been detected (Missouri Department of Natural Resources 1991).

The Southeast Drainage is located within the Missouri Department of Conservation's Weldon Spring Conservation Area in St. Charles County, Missouri. This area is actively managed for wildlife, contains a variety of terrestrial and aquatic habitats, and supports a diverse biota. The vegetation, fish and wildlife, and habitats of this conservation area are described in detail in the baseline assessment (BA) that was prepared for the chemical plant area (DOE 1992). 
The terrestrial habitat along the drainage is a stable, mature hardwood forest community of very high quality. Many of the trees range in age from 40 to 80 years, and a large number of trees are more than 100 years old. Common tree species include oak, maple, hickory, and sycamore. The drainage provides suitable habitat for a variety of wildlife, including amphibians, reptiles, birds, and mammals. Recent biotic surveys within the drainage have indicated the presence of a rather diverse amphibian community (10 species) that includes a state rare species and the first county record for the dark-sided salamander. No suitable habitat for waterfowl occurs along the Southeast Drainage. Because of its intermittent and losing nature, the drainage supports a limited fish fauna that is restricted primarily to a few permanent spring-fed pools and to the lowermost portion of the drainage near its confluence with the Missouri River.

Although a variety of fish have been observed in pool habitats in the vicinity of springs SP-5303 and SP-5304, to date only the green sunfish has been collected from these habitats. The very limited fish fauna of this reach of the drainage is most likely a consequence of the overall absence of permanent aquatic habitat within all but the lowermost portions of the drainage. Seven species have been collected in sampling of the lower reaches of the drainage near its confluence with the Missouri River; they are all common species in Missouri and typical of small drainages throughout the Midwest. These latter species likely move regularly between the Missouri River and the Southeast Drainage and probably leave the drainage for permanent habitats in the river as flows in the drainage become intermittent.

Although a number of federal-listed threatened, endangered, and candidate species have been identified by the U.S. Fish and Wildlife Service as occurring in the area (Tieger 1988; Nash 1990), none of these species are expected to use habitats in the Southeast Drainage. Several statelisted species also occur in the area, and some may use the drainage. The state rare wood frog, a forest-floor-dwelling species, has been found in the Southeast Drainage, and the state rare Cooper's hawk could use terrestrial habitats along the drainage. The western sand darter is a state watch-listed species that has been reported from St. Charles County and may be present in the lowermost reaches of the Southeast Drainage. However, surveys in the drainage have not found this species.

The Weldon Spring area has a modified continental climate characterized by moderately cold winters and warm summers. The average temperature in the region is $13^{\circ} \mathrm{C}\left(55.4^{\circ} \mathrm{F}\right)$; the average daily maximum and minimum temperatures are $31.7^{\circ} \mathrm{C}\left(89.0^{\circ} \mathrm{F}\right)$ and $-6.7^{\circ} \mathrm{C}\left(19.9^{\circ} \mathrm{F}\right)$, respectively. The normal annual precipitation in the area is $86.1 \mathrm{~cm}$ (33.9 in.) (Bair 1992).

A review of existing file/literature information regarding archaeological and historic resources of the Southeast Drainage area and an archaeological field survey and evaluation were conducted for DOE in 1990 (Walters 1990a-b). The field survey entailed a surface examination of the streambed and exposed cutbanks. One prehistoric lithic artifact (projectile point) was recovered from the streambed; the artifact exhibited evidence of extensive water transport and probably had been redeposited. No archaeological remains were observed in the exposed stream cutbanks. One historic period site (farmstead location) is located at the creek mouth near the confluence with the Missouri River; structures associated with this farmstead were demolished when the U.S. Army 
acquired the property. No evidence was found of significant cultural remains in the area directly affected by the stream. Neither the isolated prehistoric artifact nor the historic farmstead location appears likely to meet eligibility criteria for listing in the National Register of Historic Places.

\subsection{ANALYTICAL DATA}

Analytical data for sediment and surface water were compiled and analyzed to perform a risk assessment that can be used to support a decision regarding remediation of the Southeast Drainage. A separate discussion that includes information and justification for data used is provided for each medium.

\subsubsection{Sediment}

The Southeast Drainage was originally surveyed for radioactive sediment contamination in 1984 by Oak Ridge Associated Universities (ORAU) (Deming 1986; Boerner 1986). The purpose of the survey was to identify radioactively contaminated areas outside of the chemical plant area boundary to be designated as vicinity properties. The results of the survey indicated that sediment in the drainage was radioactively contaminated in a heterogeneous manner. The ORAU survey results for sediment samples indicated concentrations ranging from levels that are typical of background soil in the area to a maximum concentration of $210 \mathrm{pCi} / \mathrm{g}$ for radium-226, $240 \mathrm{pCi} / \mathrm{g}$ for radium-228, 1,000 $\mathrm{pCi} / \mathrm{g}$ for uranium-238, and $10,000 \mathrm{pCi} / \mathrm{g}$ for thorium- 230 . The average measured background concentration of uranium-238, thorium-230, radium-228, and radium-226 is $1.2 \mathrm{pCi} / \mathrm{g}$ for each radionuclide (DOE 1992). Sediment sampling was conducted (MK-Ferguson Company and Jacobs Engineering Group 1996) to obtain more recent radiological and chemical data covering the length of the drainage, including locations identified as contaminated by ORAU in 1984. Because survey markers used to conduct the ORAU survey are no longer present in the drainage and conditions in the drainage may have changed in the 10 years that have elapsed since the ORAU survey was performed, the exact ORAU sampling locations could not be identified. The results of the ORAU survey were used to guide the recent sampling effort in terms of sampling locations and radiological parameters analyzed.

Planning for the recent sediment sampling (MK-Ferguson Company and Jacobs Engineering Group 1996) included dividing the drainage into four segments (A, B, C, and D); segmentation was done to facilitate identification of exposure units based on accessibility and likelihood of exposure and to determine technical feasibility with respect to mobilization of conventional excavation and hauling equipment (MK-Ferguson Company and Jacobs Engineering Group 1995). Radiological characterization data collected within each segment of the drainage included a gamma walkover survey and systematic and biased soil samples collected from surface and subsurface increments. The procedures used to conduct the walkover survey and the soil sampling are described in the sampling report (MK-Ferguson Company and Jacobs Engineering Group 1996). Soil sampling locations and segmentation of the drainage are depicted in Figure 2. 


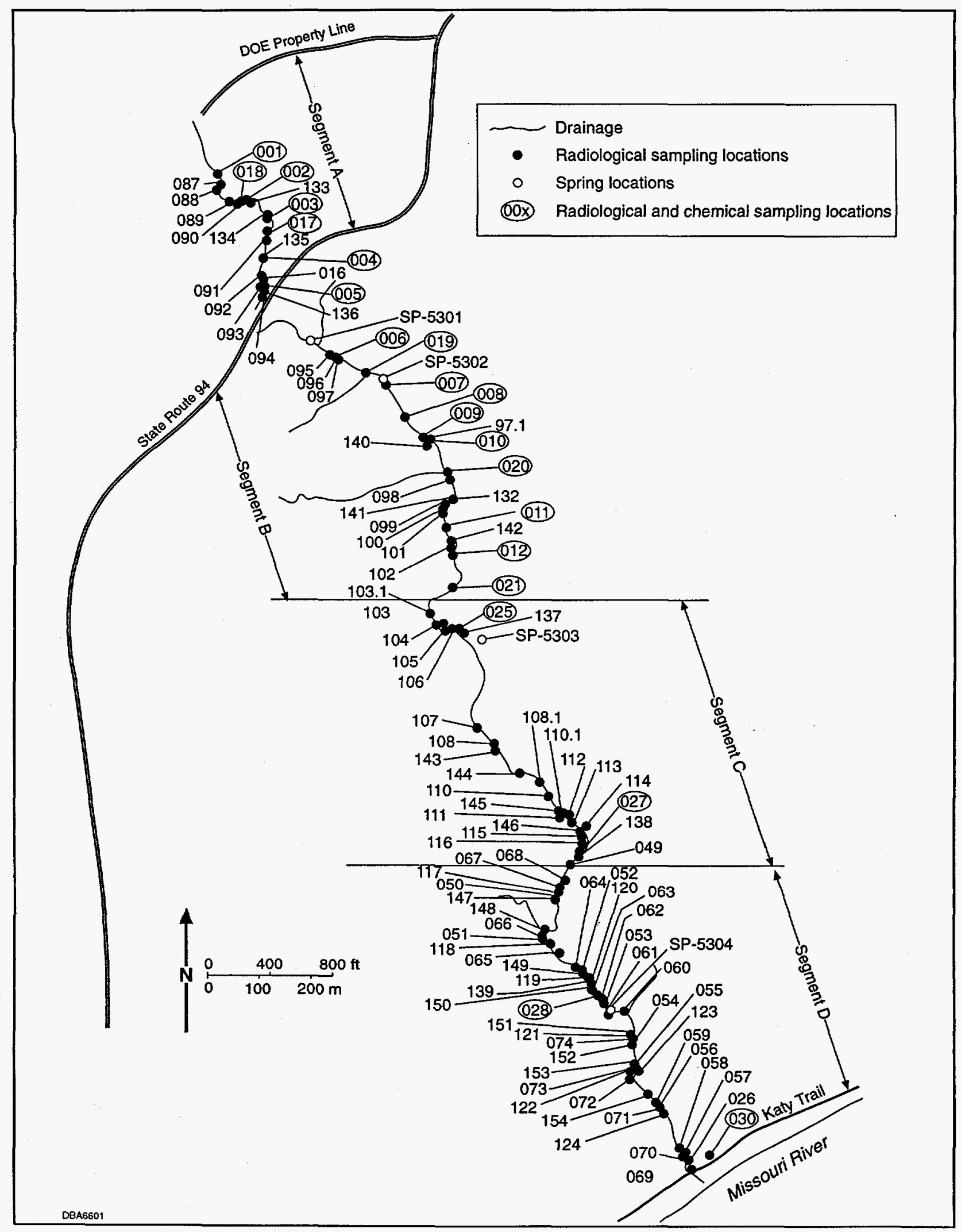

FIGURE 2 Sediment Sampling Locations and Segmentation of the Southeast Drainage 
Each soil sample was analyzed for uranium-238, radium-226, radium-228, and thorium-230. Concentrations of other radionuclides in the uranium-238 and thorium-232 decay series can be determined from these principal radionuclides by assuming secular equilibrium, in which the activities of the associated decay products are equal to those of the principal radionuclides (see Section 2.3.2.1 of the BA for the chemical plant area [DOE 1992]). The radiological data collected for each segment are summarized in Table 1. In general, the results of the recent sampling are consistent with the results of the ORAU survey. Radiological risk calculations for this EE/CA focused on data collected from the recent sampling effort because these data are believed to represent current conditions in the Southeast Drainage. In addition, a data-sufficiency exercise was performed to ensure that the radiological data were sufficient to support a risk-based decision for the drainage (Black and Carlson 1996).

Various studies conducted before the recent sampling effort included limited characterization of the chemical content of drainage sediment (MK-Ferguson Company and Jacobs Engineering Group 1989; Bethel et al. 1993; IT Corporation 1992; Environmental Science \& Engineering 1993). These studies focused mainly on characterizing metals and nitroaromatic compounds but also included some analysis for polychlorinated biphenyls (PCBs) and other organic compounds. Samples were obtained from all four segments in the drainage. These sampling efforts did not reveal any contamination with nitroaromatic compounds or PCBs. Several metals including cadmium, copper, manganese, mercury, and zinc - may have been somewhat elevated with respect to background soil levels presented in the BA for the chemical plant area (DOE 1992). However, it is not clear that the levels were statistically significantly different from background.

Sediment samples collected from the recent sampling effort were also analyzed for metals, nitroaromatic compounds, and PCBs. Eight composite samples representing 21 locations covering the length of the drainage were collected. The results of these composite samples were similar to those from previous characterization efforts, with the exception that low levels of nitroaromatic compounds were detected in a composite sample from Segment B, and low levels of PCBs were detected in two composites representing sampling locations within Segments A, C, and D. To further delineate PCB concentrations within these segments, discrete samples were collected from the locations where the composite samples were taken. A total of seven samples were collected; four from Segment A, two from Segment C, and one from Segment D. The results for samples from Segment A ranged from 0.035 to $3.0 \mathrm{mg} / \mathrm{kg}$; the two samples from Segment $C$ were reported at 0.061 to $150 \mathrm{mg} / \mathrm{kg}$; and the sample from Segment D was reported at $0.048 \mathrm{mg} / \mathrm{kg}$. Another round of sampling was performed to delineate PCB concentrations at the location where the value of $150 \mathrm{mg} / \mathrm{kg}$ was detected; this location also exhibited high concentrations of radioactive contaminants (i.e., sample ID 025). Fourteen samples were collected representing depths to approximately $2 \mathrm{ft}$ below surface. The PCB results from this round of sampling ranged from 0.024 to $5.0 \mathrm{mg} / \mathrm{kg}$ (MK-Ferguson Company and Jacobs Engineering Group 1996). The chemical data for each segment of the Southeast Drainage are summarized in Table 1. The table includes data from previous chemical analyses and from the recent chemical composite sampling event. Radiological data presented are results from the recent sampling events. Human health risk calculations presented in 
TABLE 1 Summary of Sediment Data in the Southeast Drainage

\begin{tabular}{|c|c|c|c|c|c|c|c|c|c|c|c|c|}
\hline \multirow[b]{2}{*}{ Parameter } & \multicolumn{3}{|c|}{ Segment A } & \multicolumn{3}{|c|}{ Segment B } & \multicolumn{3}{|c|}{ Segment C } & \multicolumn{3}{|c|}{ Segment D } \\
\hline & $\mathrm{DF}^{\mathrm{a}}$ & Range $^{b}$ & $\mathrm{UCL}^{\mathrm{c}}$ & $\mathrm{DF}^{\mathrm{a}}$ & Range $^{b}$ & $\mathrm{UCL}^{\mathrm{c}}$ & $\mathrm{DF}^{\mathrm{a}}$ & Range $^{b}$ & $\mathrm{UCL}^{\mathrm{c}}$ & $\mathrm{DF}^{\mathrm{a}}$ & Range $^{b}$ & $\mathrm{UCL}^{\mathrm{c}}$ \\
\hline \multicolumn{13}{|c|}{ Radionuclides (pCi/g) } \\
\hline Radium-226 & $34 / 34$ & $1.1-170$ & 35 & $24 / 24$ & $0.3-260$ & 87 & $53 / 53$ & $0.95-360$ & 86 & $120 / 120$ & $0.89-160$ & 34 \\
\hline Radium-228 & $34 / 34$ & $0.6-330$ & 23 & $24 / 24$ & $0.7-19$ & 5.5 & $53 / 53$ & $0.8-36$ & 7.8 & $121 / 121$ & $0.14-86$ & 8.9 \\
\hline Thorium-230 & $34 / 34$ & $0.2-430$ & 62 & $24 / 24$ & $0.3-4,900$ & 970 & $53 / 53$ & $1.0-1,700$ & 290 & $128 / 128$ & $0.5-7,900$ & 580 \\
\hline Uranium-238 & $34 / 34$ & 14-330 & 120 & $24 / 24$ & $2.6-120$ & 60 & $53 / 53$ & $1.2-740$ & 160 & $128 / 128$ & $0.9-280$ & 74 \\
\hline \multicolumn{13}{|l|}{ Metals (mg/kg) } \\
\hline Aluminum & $4 / 4$ & $8,800-16,000$ & 16,000 & $4 / 4$ & $7,100-18,000$ & 16,000 & $3 / 3$ & $9,100-13,000$ & 15,000 & $6 / 6$ & $3,200-22,000$ & 18,000 \\
\hline Antimony & $0 / 4$ & $-d$ & 2.9 & $0 / 4$ & - & 2.9 & $0 / 3$ & - & 3.5 & $0 / 6$ & - & 3.1 \\
\hline Arsenic & $4 / 4$ & $11-26$ & 24 & $5 / 5$ & $4.7-14$ & 14 & $10 / 10$ & $1.6-14$ & 11 & $11 / 11$ & $3.7-13$ & 10 \\
\hline Barium & $4 / 4$ & $150-700$ & 700 & $5 / 5$ & $110-270$ & 270 & $10 / 10$ & $49-270$ & 210 & $9 / 9$ & $140-260$ & 220 \\
\hline Beryllium & $4 / 4$ & $0.56-1.0$ & 1.0 & $4 / 4$ & $0.50-1.0$ & 1.0 & $3 / 3$ & $0.61-1.0$ & 1.3 & $6 / 6$ & $0.60-1.0$ & 1.0 \\
\hline Cadmium & $2 / 4$ & $1.1-2.4$ & 2.1 & $2 / 5$ & $0.78-0.86$ & 0.79 & $4 / 10$ & $0.40-2.8$ & 1.3 & $3 / 9$ & $0.84 \cdot 1.5$ & 1.0 \\
\hline Calcium & $4 / 4$ & $5,400-33,000$ & 29,000 & $4 / 4$ & $2,300-20,000$ & 17,000 & $3 / 3$ & $3,100-33,000$ & 42,000 & $6 / 6$ & $2,500-40,000$ & 30,000 \\
\hline Chromium & $4 / 4$ & $25-130$ & 120 & $5 / 5$ & 9.8-32 & 28 & $12 / 12$ & $6.5-49$ & 25 & $11 / 11$ & 6.3-53 & 30 \\
\hline Cobalt & $4 / 4$ & $12-37$ & 33 & $4 / 4$ & $9.0-29$ & 31 & $3 / 3$ & $11-26$ & 31 & $6 / 6$ & $8.0-19$ & 15 \\
\hline Copper & $4 / 4$ & $12-110$ & 100 & $4 / 4$ & 6.6-16 & 17 & $5 / 5$ & $8.1-170$ & 110 & $8 / 8$ & $2.5-36$ & 26 \\
\hline Iron & $4 / 4$ & $8,400-31,000$ & 34,000 & $4 / 4$ & $11,000-27,000$ & 27,000 & $3 / 3$ & $15,000-21,000$ & 23,000 & $6 / 6$ & $8,600-26,000$ & 22,000 \\
\hline Lead & $4 / 4$ & $48-120$ & 110 & $5 / 5$ & $21-43$ & 39 & $12 / 12$ & $10-48$ & 34 & $17 / 17$ & 4.3-48 & 21 \\
\hline Lithium & $3 / 3$ & 5.3-11 & 14 & $3 / 3$ & 4.8-7.1 & 7.8 & $1 / 1$ & 11 & 11 & $2 / 2$ & 11 & 11 \\
\hline Magnesium & $4 / 4$ & $1,600-4,800$ & 5,200 & $4 / 4$ & $1,100-2,900$ & 2,700 & $3 / 3$ & $1,800-2,300$ & 2,400 & $6 / 6$ & $660-6,400$ & 5,100 \\
\hline Manganese & $4 / 4$ & $850-3,300$ & 2,900 & $4 / 4$ & $880-2,600$ & 2,800 & $5 / 5$ & $470-2,600$ & 2,100 & $8 / 8$ & $580-6,500$ & 3,100 \\
\hline Mercury & $3 / 4$ & $0.29-4.2$ & 3.7 & $2 / 5$ & $0.06-0.41$ & 0.28 & $2 / 10$ & $0.89-1.6$ & 0.59 & $9 / 15$ & $0.05-7.0$ & 2.0 \\
\hline Molybdenum & $3 / 3$ & $1.9-6.4$ & 7.7 & $2 / 3$ & $2.6-3.2$ & 4.6 & $1 / 1$ & 2.7 & 2.7 & $2 / 2$ & $1.6-2.7$ & 5.6 \\
\hline Nickel & $4 / 4$ & $21-35$ & 35 & $4 / 4$ & $12-28$ & 31 & $3 / 3$ & $26-66$ & 78 & $6 / 6$ & $21-28$ & 28 \\
\hline Potassium & $4 / 4$ & $560-1,200$ & 1,100 & $4 / 4$ & $710-960$ & 930 & $3 / 3$ & $730-1,100$ & 1,300 & $5 / 6$ & $1,100-2,500$ & 2,100 \\
\hline Selenium & $2 / 4$ & $0.61-0.69$ & 0.74 & $3 / 5$ & $0.41-0.53$ & 0.51 & $3 / 10$ & $0.45-0.69$ & 0.44 & $3 / 9$ & $0.34-1.4$ & 1.2 \\
\hline Silver & $2 / 4$ & $2.8-13$ & 11 & $1 / 5$ & 1.1 & 0.85 & $4 / 12$ & $0.96-3.4$ & 1.6 & $3 / 15$ & $0.80-5.1$ & 1.6 \\
\hline Sodium & $3 / 4$ & $34-88$ & 220 & $3 / 4$ & $30-250$ & 220 & $1 / 3$ & 130 & 320 & $2 / 6$ & $130-160$ & 260 \\
\hline Thallium & $0 / 4$ & - & 0.44 & $0 / 4$ & - & 0.44 & $0 / 3$ & - & 0.74 & $0 / 6$ & - & 0.53 \\
\hline Vanadium & $4 / 4$ & $45-75$ & 72 & $4 / 4$ & $21-51$ & 55 & $3 / 3$ & $30-46$ & 51 & $6 / 6$ & $14-51$ & 46 \\
\hline Zinc & $4 / 4$ & $120-710$ & 630 & $5 / 5$ & $33-88$ & 90 & $11 / 11$ & 58-160 & 110 & $12 / 12$ & $25-98$ & 76 \\
\hline
\end{tabular}




\section{TABLE 1 (Cont.)}

\begin{tabular}{|c|c|c|c|c|c|c|c|c|c|c|c|c|}
\hline \multirow[b]{2}{*}{ Parameter } & \multicolumn{3}{|c|}{ Segment A } & \multicolumn{3}{|c|}{ Segment B } & \multicolumn{3}{|c|}{ Segment C } & \multicolumn{3}{|c|}{ Segment D } \\
\hline & $\mathrm{DF}^{\mathrm{a}}$ & Range $^{b}$ & $\mathrm{UCL}^{\mathrm{c}}$ & $\mathrm{DF}^{\mathrm{a}}$ & Range $^{b}$ & $\mathrm{UCL}^{\mathrm{c}}$ & $\mathrm{DF}^{\mathrm{a}}$ & Range $^{b}$ & $\mathrm{UCL}^{\mathrm{c}}$ & $\mathrm{DF}^{\mathrm{a}}$ & Range $^{b}$ & $\mathrm{UCL}^{\mathrm{c}}$ \\
\hline \multicolumn{13}{|l|}{ PCBs (mg/kg) } \\
\hline Aroclor 1016 & $0 / 4$ & - & $N A^{d}$ & $0 / 4$ & - & NA & $0 / 3$ & - & $\mathrm{NA}$ & $0 / 3$ & - & NA \\
\hline Aroclor 1221 & $0 / 4$ & - & NA & $0 / 4$ & - & NA & $0 / 3$ & - & NA & $0 / 3$ & - & NA \\
\hline Aroclor 1232 & $0 / 4$ & - & NA & $0 / 4$ & - & NA & $0 / 3$ & - & NA & $0 / 3$ & - & NA \\
\hline Aroclor 1242 & $0 / 4$ & - & $\mathrm{NA}$ & $0 / 4$ & - & NA & $0 / 3$ & - & NA & $0 / 3$ & - & NA \\
\hline Aroclor 1248 & $0 / 4$ & - & NA & $0 / 4$ & - & NA & $0 / 3$ & - & NA & $0 / 3$ & - & NA \\
\hline Aroclor 1254 & $1 / 4$ & 0.32 & NA & $0 / 4$ & - & NA & $1 / 3$ & 3.9 & NA & $1 / 3$ & 3.9 & NA \\
\hline Aroclor 1260 & $1 / 4$ & 0.29 & NA & $0 / 4$ & $\therefore$ & NA & $1 / 3$ & 3.0 & NA & $1 / 3$ & 3.0 & NA \\
\hline \multicolumn{13}{|l|}{ Nitroaromatics (mg/kg) } \\
\hline 2,4,6-Trinitrotoluene & $0 / 4$ & - & NA & $0 / 18$ & - & NA & $1 / 23$ & 0.0054 & 4.5 & $0 / 20$ & - & NA \\
\hline 2,4-Dinitrotoluene & $0 / 4$ & - & NA & $1 / 4$ & 0.0023 & 0.31 & $0 / 6$ & - & NA & $0 / 7$ & - & NA \\
\hline 2,6-Dinitrotoluene & $0 / 4$ & - & NA & $0 / 4$ & - & NA & $0 / 6$ & - & NA & $0 / 7$ & - & NA \\
\hline Nitrobenzene & $0 / 4$ & - & NA & $0 / 4$ & - & NA & $0 / 6$ & - & NA & $0 / 7$ & - & NA \\
\hline 1,3,5-Trinitrobenzene & $0 / 4$ & - & NA & $0 / 4$ & - & NA & $0 / 6$ & - & NA & $0 / 7$ & - & NA \\
\hline 1,3-Dinitrobenzene & $0 / 4$ & - & NA & $1 / 4$ & 0.036 & 0.48 & $0 / 6$ & - & NA & $0 / 7$ & - & NA \\
\hline $\mathrm{m}$-Nitrotoluene & $\mathrm{NT}^{d}$ & NT & NT & NT & NT & NT & $0 / 1$ & - & NA & $0 / 1$ & - & NA \\
\hline o-Nitrotoluene & NT & NT & NT & NT & NT & NT & $0 / 1$ & - & NA & $0 / 1$ & - & NA \\
\hline p-Nitrotoluene & NT & NT & NT & NT & NT & NT & $0 / 1$ & - . & NA & $0 / 1$ & - & NA \\
\hline
\end{tabular}

a $\mathrm{DF}=$ detection frequency (number of times detected/number of samples taken).

b Range $=$ range of detected concentrations for all data (i.e., surface and subsurface).

c UCL values (one-tailed 95\% upper confidence limit of the arithmetic average) for surface sediment samples were used as exposure point concentrations. For samples reported as not detected for metals, the concentration was assumed to be half the detection limit. For nitroaromatic compounds, UCL values were not calculated when the detection frequency was zero because there is no natural background level. For a sample size of 1 , the detected value was used as the UCL for risk assessment calculations.

- NA = not applicable; NT = not tested; a hyphen indicates the parameter was not detected.

Sources: Radiological data from MK-Ferguson Company and Jacobs Engineering Group (1996); chemical data from MK-Ferguson Company and Jacobs Engineering Group (1989, 1996), Bethel et al (1993), IT Corporation (1992), Environmental Science \& Engineering (1993). 
Section 2.3.2 are based on data presented in this table. Data from discrete samples discussed above were used for risk calculations for PCBs.

Sediment samples were also collected for chemical analysis and toxicity testing to support the ecological risk assessment for the drainage (DOE 1995a). Samples were collected from two locations within the drainage, springs SP-5303 and SP-5304, and were analyzed for chromium, copper, lead, manganese, silver, zinc, and several nitroaromatic compounds. These were the constituents identified in the BA for the chemical plant area (DOE 1992) as being contaminants of ecological concern. Sediment samples were also collected from springs SP-5402 and SP-5406 within the 5400 drainage located immediately west of the Southeast Drainage. The 5400 drainage is the background drainage for all ecological investigations associated with the Southeast Drainage (DOE 1995a). Sediment samples from this background spring were analyzed for the same metals and nitroaromatics evaluated for springs SP-5303 and SP-5304.

At the background 5400 drainage, no nitroaromatic compounds were present at concentrations above detection limits, and concentrations of metals were within the lower ends of the ranges reported from the Southeast Drainage, except for copper and silver. Silver was not detected in the background sediment samples, whereas copper was present at lower concentrations $(1.2$ to $11.0 \mathrm{mg} / \mathrm{kg}$ ) than detected in the Southeast Drainage.

\subsubsection{Surface Water}

Contamination of surface water in the drainage may be attributable to four sources: (1) runoff from contaminated soil in the southern portion of the chemical plant area; (2) overflow from the Imhoff tanks located at the headwaters of the drainage, which were used to store and decant process wastes when the chemical plant was in operation; (3) desorbed contamination from sediment within the drainage; and (4) contaminated groundwater beneath the drainage. Although it is not possible to discern the contribution from each source, ongoing remediation at the chemical plant area has resulted in the recent cleanup of the majority of contaminated site soil and the removal of the Imhoff tanks and surrounding soil, which was completed in July 1994. Surface water quality is expected to continually improve because of the removal of these various sources.

Contamination of surface water was monitored at the four springs along the drainage (SP-5301, SP-5302, SP-5303, and SP-5304; Figure 2) from 1987 to 1995 as part of the Weldon Spring site environmental monitoring program. Water samples from the springs were analyzed for radionuclides, metals, inorganic anions, and nitroaromatic compounds; the sampling frequency varied for each parameter.

Surface water samples were also collected for chemical analysis and toxicity testing to support the ecological risk assessment for the drainage (DOE 1995a). Samples were collected from springs SP-5303 and SP-5304 and analyzed for chromium, copper, lead, manganese, silver, zinc, total uranium, and several nitroaromatics. Surface water samples were also collected from springs 
SP-5402 and SP-5406 within the 5400 drainage. These samples were analyzed for the same metals and nitroaromatics evaluated for springs SP-5303 and SP-5304.

Results for the Southeast Drainage indicate that radioactive contamination in surface water is limited to uranium. Analysis of radium and thorium isotopes was discontinued in 1989 because measured concentrations were at levels that are representative of naturally occurring levels.

At the background 5400 drainage, which was sampled on only one occasion, no nitroaromatic compounds were present at concentrations above detection limits. Concentrations of metals were similar to the concentrations reported from the Southeast Drainage, except for lead, manganese, and silver. At the 5400 drainage, lead and silver were not detected, and manganese was present at much higher concentrations (maximum concentrations of 196 and $285 \mu \mathrm{g} / \mathrm{L}$ ) than in the Southeast Drainage (maximum concentration of $87 \mu \mathrm{g} / \mathrm{L}$ ). Nitrate and total uranium levels in the 5400 drainage were much lower than the levels detected in the Southeast Drainage.

Higher levels of uranium (ranging up to $590 \mathrm{pCi} / \mathrm{L}$ ) have typically been measured in the uppermost reaches of the drainage, but levels decrease as the Missouri River is approached. Nitroaromatic compounds have been detected frequently at low concentrations in samples from springs SP-5303 and SP-5304; the highest concentrations are for 2,4,6-trinitrotoluene at spring SP-5303. The maximum 2,4,6-trinitrotoluene concentration of $280 \mu \mathrm{g} / \mathrm{L}$ was measured in earlier sampling (1987); current levels are one order of magnitude lower. With one exception, nitroaromatic compounds have not been detected in springs SP-5301 and SP-5302 (2,4-dinitrotoluene was detected at $0.89 \mu \mathrm{g} / \mathrm{L}$ in a sample from spring SP-5302 in one 1989 sampling round).

Surface water data are summarized in Table 2. These radiological and chemical data were used to calculate associated human health risks, which are presented in Section 2.3.3.

\subsection{RISK CALCULATIONS}

Human health risk calculations were performed using the radiological and chemical sediment and surface water analytical data presented in Tables 1 and 2. The exposure scenarios, intake parameters, and risk calculations for sediment and surface water are presented in Sections 2.3.1 through 2.3.3.

A screening-level ecological risk assessment was also conducted using the analytical data presented in Tables 1 and 2. This assessment (discussed in Section 2.3.4) included biotic surveys and toxicity testing of surface water, and evaluated risks to aquatic and terrestrial biota. It was conducted to provide a preliminary evaluation of potential risks to ecological resources within the drainage and to provide support for the remedial decision-making process. 
TABLE 2 Summary of Surface Water Data in the Southeast Drainage

\begin{tabular}{|c|c|c|c|c|c|c|c|c|c|c|c|c|}
\hline \multirow[b]{2}{*}{ Parameter } & \multicolumn{3}{|c|}{ SP-5301 } & \multicolumn{3}{|c|}{ SP-5302 } & \multicolumn{3}{|c|}{ SP-5303 } & \multicolumn{3}{|c|}{ SP-5304 } \\
\hline & $\mathrm{DF}^{\mathrm{a}}$ & Range $^{b}$ & $\mathrm{UCL}^{\mathrm{c}}$ & $\mathrm{DF}^{\mathrm{a}}$ & Range $^{b}$ & $\mathrm{UCL}^{\mathrm{c}}$ & $\mathrm{DF}^{\mathrm{a}}$ & Range $^{b}$ & $\mathrm{UCL}^{\mathrm{c}}$ & $\mathrm{DF}^{\mathrm{a}}$ & Range $^{b}$ & $\mathrm{UCL}^{\mathrm{c}}$ \\
\hline \multicolumn{13}{|c|}{ Radionuclides ( $\mathrm{pCi} / \mathrm{L}$ ) } \\
\hline Uranium, total & $19 / 19$ & $56-590$ & 360 & $16 / 16$ & $67-540$ & 350 & $31 / 31$ & $67-370$ & 200 & $31 / 31$ & 40-310 & 160 \\
\hline \multicolumn{13}{|l|}{ Metals $(\mu \mathrm{g} / \mathrm{L})$} \\
\hline Aluminum & $1 / 2$ & 205 & 480 & $0 / 1$ & - & 100 & $2 / 4$ & $91-240$ & 220 & $1 / 4$ & 29 & 110 \\
\hline Antimony & $1 / 2$ & 76 & 200 & $0 / 1$ & - & 30 & $1 / 4$ & 70 & 64 & $1 / 4$ & 73 & 66 \\
\hline Arsenic & $0 / 2$ & $-d$ & 5.0 & $0 / 1$ & - & 5 & $0 / 4$ & - & 5.7 & $0 / 4$ & - & 5.7 \\
\hline Barium & $0 / 2$ & - & 100 & $0 / 1$ & - & 100 & $2 / 4$ & $110-130$ & 130 & $2 / 4$ & $90-100$ & 100 \\
\hline Beryllium & $0 / 2$ & - & 2.5 & $0 / 1$ & - & 2.5 & $0 / 4$ & - & 2.9 & $0 / 4$ & - & 2.9 \\
\hline Cadmium & $0 / 2$ & - & 2.5 & $0 / 1$ & - & 2.5 & $0 / 4$ & - & 3.0 & $0 / 4$ & - & 3.0 \\
\hline Calcium & $2 / 2$ & $49,000-61,000$ & 92,000 & $1 / 1$ & 47,000 & 47,000 & $4 / 4$ & $\begin{array}{c}47,000- \\
88,000\end{array}$ & 96,000 & $4 / 4$ & $\begin{array}{c}53,000- \\
95,000\end{array}$ & 93,000 \\
\hline Chromium & $2 / 2$ & $14-26$ & 58 & $1 / 1$ & 14 & 14 & $3 / 6$ & $5-26$ & 19 & $3 / 6$ & $6.7-26$ & 19 \\
\hline Cobalt & $0 / 2$ & - & 25 & $0 / 1$ & - & 25 & $0 / 4$ & - & 29 & $0 / 4$ & - & 29 \\
\hline Copper & $0 / 2$ & - & 13 & $0 / 1$ & - & 13 & $2 / 6$ & $2.9-4.1$ & 11 & $1 / 5$ & 3.6 & 12 \\
\hline Iron & $1 / 2$ & 214 & 650 & $1 / 1$ & 130 & 130 & $4 / 4$ & $14-310$ & 280 & $2 / 4$ & $22-150$ & 140 \\
\hline Lead & $1 / 2$ & 15 & 49 & $0 / 1$ & - & 2.5 & $2 / 6$ & $2.0-3.0$ & 2.8 & $1 / 6$ & 0.8 & 2.2 \\
\hline Lithium & $0 / 2$ & - & 25 & $0 / 1$ & - & 25 & $0 / 4$ & - & 28 & $0 / 4$ & - & 28 \\
\hline Magnesium & $2 / 2$ & $12,000-16,000$ & 28,000 & $1 / 1$ & 11,000 & 11,000 & $4 / 4$ & $\begin{array}{c}11,000- \\
18,000\end{array}$ & 17,000 & $4 / 4$ & $9,300-15,000$ & 14,000 \\
\hline Manganese & $2 / 2$ & $18-57$ & 160 & $0 / 1$ & - & 7.5 & $5 / 6$ & $6.5-87$ & 56 & $2 / 6$ & $12-23$ & 17 \\
\hline Mercury & $0 / 2$ & - & 0.10 & $0 / 1$ & - & 0.10 & $0 / 4$ & - & 0.11 & $0 / 4$ & - & 0.11 \\
\hline Molybdenum & $1 / 2$ & 42 & 130 & $0 / 1$ & - & 10 & $3 / 4$ & $12-38$ & 36 & $3 / 4$ & $6.3-39$ & 42 \\
\hline Nickel & $0 / 2$ & - & 20 & $0 / 1$ & - & 20 & $1 / 4$ & 9.2 & 22 & $0 / 4$ & - & 23 \\
\hline Potassium & $0 / 2$ & - & 2,500 & $0 / 1$ & - & 2,500 & $2 / 4$ & $2,500-3,900$ & 3,700 & $2 / 4$ & $1,600-2,000$ & 2,700 \\
\hline Selenium & $0 / 2$ & - & 2.5 & $0 / 1$ & - & 2.5 & $0 / 4$ & - & 2.8 & $0 / 4$ & - & 2.8 \\
\hline Silver & $1 / 2$ & 6 & 8.7 & $0 / 1$ & - & 5 & $0 / 6$ & - & 3.9 & $2 / 6$ & $2.6-4.0$ & 4.4 \\
\hline Sodium & $2 / 2$ & $15,000-22,000$ & 42,000 & $1 / 1$ & 14,000 & 14,000 & $4 / 4$ & $9,700-13,000$ & 13,000 & $4 / 4$ & $5,500-11,000$ & 11,000 \\
\hline Thallium & $0 / 2$ & - & 5.0 & $0 / 1$ & - & 5 & $0 / 4$ & - & 5.7 & $0 / 4$ & - & 5.7 \\
\hline Vanadium & $0 / 2$ & - & 25 & $0 / 1$ & - & 25 & $1 / 4$ & 26 & 33 & $1 / 4$ & 24 & 33 \\
\hline Zinc & $1 / 2$ & 30 & 83 & $0 / 1$ & - & 10 & $5 / 6$ & $6.9-40$ & 31 & $5 / 6$ & $2.8-31$ & 21 \\
\hline
\end{tabular}




\section{TABLE 2 (Cont.)}

\begin{tabular}{|c|c|c|c|c|c|c|c|c|c|c|c|c|}
\hline \multirow[b]{2}{*}{ Parameter } & \multicolumn{3}{|c|}{ SP-5301 } & \multicolumn{3}{|c|}{ SP-5302 } & \multicolumn{3}{|c|}{ SP-5303 } & \multicolumn{3}{|c|}{ SP-5304 } \\
\hline & $\mathrm{DF}^{\mathrm{a}}$ & Range $^{\mathrm{b}}$ & $\mathrm{UCL}^{\mathrm{c}}$ & $\mathrm{DF}^{\mathrm{a}}$ & Range $^{b}$ & $\mathrm{UCL}^{\mathrm{c}}$ & $\mathrm{DF}^{\mathrm{a}}$ & Range $^{b}$ & $\mathrm{UCL}^{\mathrm{c}}$ & $\mathrm{DF}^{\mathrm{a}}$ & Range $^{b}$ & $\mathrm{UCL}^{\mathrm{c}}$ \\
\hline \multicolumn{13}{|l|}{ Inorganic anions $(\mathrm{mg} / \mathrm{L})$} \\
\hline Chloride & $6 / 6$ & $5.1-24$ & 19 & $4 / 4$ & $4.8-26$ & 26 & $7 / 7$ & $4.2-13$ & 12 & $7 / 7$ & $3.1-18$ & 12 \\
\hline Fluoride & $4 / 6$ & $0.36-0.60$ & 0.48 & $4 / 4$ & $0.30-0.40$ & 0.42 & $5 / 5$ & $0.30-0.60$ & 0.55 & $3 / 5$ & $0.32-0.50$ & 0.47 \\
\hline Nitrate & $6 / 6$ & $1.5-35$ & 23 & $4 / 4$ & $2.0-31$ & 31 & $13 / 13$ & $0.20-18$ & 7.1 & $12 / 12$ & $0.43-9.1$ & 4.6 \\
\hline Sulfate & $6 / 6$ & $31-82$ & 78 & $4 / 4$ & $32-210$ & 190 & $10 / 11$ & 34-67 & 60 & $10 / 10$ & $26-59$ & 50 \\
\hline \multicolumn{13}{|l|}{ Nitroaromatics $(\mu \mathrm{g} / \mathrm{L})$} \\
\hline 2,4,6-Trinitrotoluene & $0 / 6$ & - & $N A^{d}$ & $0 / 4$ & - & NA & $13 / 13$ & $0.16-280$ & 80 & $10 / 11$ & $0.43-4.8$ & 2.5 \\
\hline 2,4-Dinitrotoluene & $0 / 6$ & - & NA & $1 / 4$ & 0.89 & 0.65 & $6 / 13$ & $0.060-11$ & 3.0 & $6 / 11$ & $0.060-0.1$ & 0.10 \\
\hline 2,6-Dinitrotoluene & $0 / 6$ & - & NA & $0 / 4$ & - & NA & $7 / 13$ & $0.070-11$ & 3.0 & $7 / 11$ & $0.07-0.4$ & 0.26 \\
\hline Nitrobenzene & $0 / 6$ & - & NA & $0 / 4$ & - & NA & $1 / 13$ & 0.87 & 1.3 & $0 / 11$ & - & NA \\
\hline 1,3,5-Trinitrobenzene & $0 / 6$ & - & NA & $0 / 4$ & - & NA & $10 / 13$ & $0.06-0.47$ & 1.2 & $5 / 11$ & $0.030-0.42$ & 0.13 \\
\hline 1,3-Dinitrobenzene & $0 / 6$ & - & NA & $0 / 4$ & - & NA & $1 / 13$ & 0.81 & 1.2 & $0 / 11$ & - & NA \\
\hline $\begin{array}{l}\text { 2-Amino-4,6-dinitro- } \\
\text { toluene }\end{array}$ & $\mathrm{NT}^{\mathrm{d}}$ & NT & NT & NT & $\mathrm{NT}$ & NT & $1 / 1$ & 4.7 & 4.7 & $1 / 1$ & 1.2 & 1.2 \\
\hline $\begin{array}{l}\text { 4-Amino-2,6-dinitro- } \\
\text { toluene }\end{array}$ & NT & NT & NT & NT & NT & NT & $1 / 1$ & 5.8 & 4.7 & $1 / 1$ & 2.4 & 2.4 \\
\hline
\end{tabular}

a $\mathrm{DF}=$ detection frequency (number of times detected/number of samples taken).

b Range $=$ range of detected concentrations.

c UCL $=$ one-tailed $95 \%$ upper confidence limit of the arithmetic average; for samples reported as not detected, the concentration was assumed to be half the detection limit. For nitroaromatic compounds, UCLs were not calculated when the detection frequency was zero because there is no natural background level. For a sample size of 1 (i.e., SP-5302 metals), the detected value was used as the UCL for risk assessment calculations.

d A hyphen indicates the parameter was not detected; NT = not tested; NA = not applicable. 


\subsubsection{Exposure Assessment and Risk Characterization}

Land use for the Weldon Spring Conservation Area, in which the Southeast Drainage is located, is recreational and is expected to remain recreational in the future. Developed hiking trails do not exist along the drainage, and discussions with the Missouri Department of Conservation indicate that there are no plans to further develop this area. The most accessible area of the drainage is believed to be Segment D; this segment can be accessed from Katy Trail, which is actively used for hiking and biking. Current land-use information indicates that hunting is allowed in the area of the drainage, with restrictions as appropriate for individual species (Missouri Department of Conservation 1989). Species hunted in the area include rabbit, squirrel, dove, deer, and turkey. Two exposure scenarios were developed on the basis of this information: a most likely current scenario and a maximum future scenario. For the most likely current scenario, it was assumed that a hunter would regularly hunt in the vicinity of the drainage. For the future scenario, it was assumed that a home could be built in the vicinity of the drainage, allowing a child to access the drainage for use as a play area.

For both the hunter and child scenarios, the potentially significant modes of exposure are incidental ingestion of sediment, external irradiation, and ingestion of surface water from one of the springs. Inhalation of contaminated particulates and radon was not considered to be relevant because of the dense vegetation and high moisture content of many areas. Dermal exposure to sediment was evaluated qualitatively because of limitations in the methodology for evaluating this pathway (EPA 1992).

Exposure point concentrations for sediment were calculated for each exposure unit (i.e., segment) by using the one-tailed $95 \%$ upper confidence limit of the arithmetic average (UCL) or the maximum, whichever was lower (per EPA guidance; see EPA 1989). The equation to calculate the UCL is provided in Section 3.1 of the BA for the chemical plant area (DOE 1992). For radionuclides, all surface data were combined to calculate the exposure point concentration for each exposure segment. Collocated samples (i.e., samples taken in close proximity) and duplicate analyses were averaged before the UCL was calculated. Subsurface data were not used because statistical comparison between surface and subsurface data indicated that the levels were comparable. These data are, however, included in the location-specific analysis presented in Appendix A. The purpose of these calculations was to focus on identifying selected areas for remediation. For chemicals, UCL values for each segment for metals and nitroaromatic compounds are shown in Table 1. As discussed in Section 2.2.1, PCB results from discrete samples were used for risk calculations. The UCL values for Segments A, C, and D were 3.0, 26, and $0.048 \mathrm{mg} / \mathrm{kg}$, respectively. No UCL value was derived for Segment B because the samples collected have been reported as nondetects. Surface water calculations were performed by using the UCL concentrations or maximums calculated for each spring, as presented in Table 2. The intake parameters for each scenario are listed in Table 3.

Contaminant intakes for chemicals were calculated by using the equations provided in Section 3.4 of the BA for the chemical plant area (DOE 1992). Toxicity values for chemicals (i.e., reference doses and slope factors) were obtained from the Integrated Risk Information System 
TABLE 3 Exposure Scenario Assumptions and Intake Parameters

\begin{tabular}{|c|c|c|c|}
\hline \multirow[b]{2}{*}{ Parameter } & \multirow[b]{2}{*}{ Units } & \multicolumn{2}{|c|}{ Scenario } \\
\hline & & $\begin{array}{l}\text { Current } \\
\text { Hunter }\end{array}$ & $\begin{array}{c}\text { Future } \\
\text { Child }\end{array}$ \\
\hline Exposure time & h/event & 4 & 4 \\
\hline Exposure frequency & events/yr & 20 & 90 \\
\hline Exposure duration & $\mathrm{yr}$ & 10 & 10 \\
\hline Body weight & $\mathrm{kg}$ & 70 & 40 \\
\hline Sediment ingestion rate & mg/event & 100 & 100 \\
\hline Surface water ingestion rate & mL/event & 200 & 200 \\
\hline Radius of contaminated area & m & 2 & 2 \\
\hline Depth of contaminated area & m & 1 & 1 \\
\hline Fraction of ingested sediment from elevated areas & unitless & 1 & 1 \\
\hline Fraction of time spent in elevated areas & unitless & 0.25 & 0.25 \\
\hline
\end{tabular}

(EPA 1995) and the Health Effects Assessment Summary Tables (EPA 1994). These values were used to calculate carcinogenic risks (i.e., increased probability of developing cancer over a lifetime) and hazard quotients (i.e., measures of the potential for adverse health effects other than cancer; a hazard quotient of greater than 1 for an individual chemical indicates a potential for adverse health effects from the exposure). Hazard quotients for individual chemicals were aggregated into hazard indexes, which are used as preliminary indicators of potential for adverse health effects (a hazard index of greater than 1 indicates a need for further evaluation of the exposure). Detailed explanations of methods used to evaluate chemical toxicity are provided in Chapters 4 and 5 of the BA for the chemical plant area (DOE 1992).

The doses associated with exposure to radioactive contaminants were calculated with the equations provided in the BA for the chemical plant area (DOE 1992) and are provided in Appendix A of this EE/CA. Doses from the external gamma irradiation pathway were calculated on the basis of information from the radiological survey, which indicated an average area of contamination of about $10 \mathrm{~m}^{2}\left(100 \mathrm{ft}^{2}\right)$. Contamination in the drainage is localized, comprising only about $25 \%$ or less of the drainage area. Therefore, for calculating the external gamma doses, it was assumed that only $25 \%$ of the exposure time was spent in areas with elevated radionuclide concentrations because a receptor would be likely to move around the drainage. However, the entire amount of ingested sediment was assumed to be from areas with elevated contaminant levels. Radiological doses were converted to carcinogenic risks by using a risk factor of $6 \times 10^{-7} / \mathrm{mrem}$. The justification for this risk factor is provided in Section 4.1 of the BA for the chemical plant area (DOE 1992). 


\subsubsection{Human Health Risks from Exposure to Sediment}

The radiological risks from the combined pathways of ingestion of sediment and external gamma irradiation are presented in Table 4 for each exposure segment and scenario. Estimated risks for both the current and future use scenarios are within the range considered acceptable for Superfund sites, which is $1 \times 10^{-6}$ to $1 \times 10^{-4}$ (EPA 1990). The total risk for the hunter scenario ranges from $1 \times 10^{-5}$ in Segments $A$ and $D$ to $2 \times 10^{-5}$ in Segments $B$ and $C$. The total risk for the future child scenario ranges from $5 \times 10^{-5}$ in Segments A and D to $1 \times 10^{-4}$ in Segment $B$. The major contributor to risk is radium-226.

The chemical carcinogenic risks and hazard indexes from ingestion of sediment are presented in Table 5. Because of the limited amount of data for background concentrations of metals and anions, all parameters listed in Tables 1 and 2 were included in the risk calculations (i.e., none were excluded through comparison with background). Risks for the current hunter scenario range from $2 \times 10^{-7}$ to $2 \times 10^{-6}$, and risks for the future child scenario range from $2 \times 10^{-6}$ to $2 \times 10^{-5}$.

Hazard indexes range from 0.01 to 0.06 for the hunter scenario and from 0.1 to 0.5 for the child scenario. The chemical risks and hazard indexes in all segments do not indicate a concern with respect to human health. The low levels of nitroaromatic compounds detected in single samples from Segments $B$ and $C$ correspond to very low cancer risks (i.e., $1 \times 10^{-10}$ for 2,4-dinitrotoluene in Segment B and $1 \times 10^{-11}$ for 2,4,6-trinitrotoluene in Segment C).

The hazard indexes are all less than 1 . In all cases, uranium was the single highest contributor to the hazard index level (e.g., uranium contributed $87 \%$ of the highest hazard index, which was for Segment C). This finding is consistent with the characterization results of elevated concentrations of uranium in selected locations of the drainage.

TABLE 4 Estimated Radiological Risks from Exposure to Sediment ${ }^{\text {a }}$

\begin{tabular}{|c|c|c|c|c|c|c|}
\hline \multirow[b]{2}{*}{$\begin{array}{l}\text { Drainage } \\
\text { Segment }\end{array}$} & \multicolumn{3}{|c|}{ Current Hunter } & \multicolumn{3}{|c|}{ Hypothetical Future Child } \\
\hline & Ingestion & $\begin{array}{l}\text { External } \\
\text { Gamma }\end{array}$ & Total & Ingestion & $\begin{array}{l}\text { External } \\
\text { Gamma }\end{array}$ & Total \\
\hline A & $5 \times 10^{-6}$ & $6 \times 10^{-6}$ & $1 \times 10^{-5}$ & $2 \times 10^{-5}$ & $3 \times 10^{-5}$ & $5 \times 10^{-5}$ \\
\hline $\mathbf{B}$ & $1 \times 10^{-5}$ & $8 \times 10^{-6}$ & $2 \times 10^{-5}$ & $7 \times 10^{-5}$ & $4 \times 10^{-5}$ & $1 \times 10^{-4}$ \\
\hline $\mathrm{C}$ & $1 \times 10^{-5}$ & $9 \times 10^{-6}$ & $2 \times 10^{-5}$ & $5 \times 10^{-5}$ & $4 \times 10^{-5}$ & $9 \times 10^{-5}$ \\
\hline $\mathrm{D}$ & $8 \times 10^{-6}$ & $4 \times 10^{-6}$ & $1 \times 10^{-5}$ & $3 \times 10^{-5}$ & $2 \times 10^{-5}$ & $5 \times 10^{-5}$ \\
\hline
\end{tabular}

a Estimated risks are summed over all radionuclides. 
TABLE 5 Estimated Chemical Carcinogenic Risks and Hazard Indexes from Exposure to Sediment ${ }^{\mathbf{a}}$

\begin{tabular}{|c|c|c|c|c|}
\hline \multirow[b]{2}{*}{$\begin{array}{l}\text { Drainage } \\
\text { Segment }\end{array}$} & \multicolumn{2}{|c|}{ Carcinogenic Risk } & \multicolumn{2}{|c|}{ Hazard Index } \\
\hline & $\begin{array}{l}\text { Current } \\
\text { Hunter }\end{array}$ & $\begin{array}{l}\text { Future } \\
\text { Child }\end{array}$ & $\begin{array}{l}\text { Current } \\
\text { Hunter }\end{array}$ & $\begin{array}{l}\text { Future } \\
\text { Child }\end{array}$ \\
\hline A & $8 \times 10^{-7}$ & $7 \times 10^{-6}$ & 0.03 & 0.2 \\
\hline B & $3 \times 10^{-7}$ & $3 \times 10^{-6}$ & 0.01 & 0.1 \\
\hline $\mathrm{C}$ & $2 \times 10^{-6}$ & $2 \times 10^{-5}$ & 0.06 & 0.5 \\
\hline $\mathrm{D}$ & $2 \times 10^{-7}$ & $2 \times 10^{-6}$ & 0.01 & 0.1 \\
\hline
\end{tabular}

a Chemical carcinogenic risks included all detected carcinogens listed in Table 1 (i.e., 2,4,6-trinitrotoluene, 2,4-dinitrotoluene, 2,6-dinitrotoluene, PCBs, arsenic, and beryllium). Hazard indexes include all parameters listed in Table 1, except those without available reference dose values (i.e., 2,6-dinitrotoluene, 1,3-dinitrobenzene, aluminum, calcium, cobalt, iron, lead, lithium, magnesium, potassium, and sodium). Organic compounds were included only when detected.

Of the chemicals of potential concern in sediment, only PCBs have been found to be absorbed through the skin to any significant extent in laboratory experiments (EPA 1992); 2,4,6-trinitrotoluene absorption has been observed but not quantified. Up to 20\% PCB absorption has been observed from mineral oil, but absorption from soil would be much lower. Even assuming $20 \%$ absorption from soil, the maximum carcinogenic risk that could be associated with dermal PCB exposure would be much less than the risk from the oral pathway. Any additional risks from dermal absorption of trinitrotoluene would likely be small because of the very low concentrations of this substance in isolated drainage locations.

\subsubsection{Human Health Risks from Exposure to Surface Water}

The radiological and chemical risks and hazard indexes calculated for each spring are summarized in Table 6. The risk from surface water does not exceed the acceptable risk level. Furthermore, these risk levels are estimated to represent the worst case because contamination levels in surface water are anticipated to decrease over time with the removal of sources at the chemical plant area and any future removal of sediment in the drainage. 
TABLE 6 Estimated Radiological and Chemical Carcinogenic Risks and Hazard Indexes from Ingestion of Surface Water ${ }^{a}$

\begin{tabular}{|c|c|c|c|c|c|c|}
\hline \multirow[b]{2}{*}{ Spring } & \multicolumn{2}{|c|}{ Radiological Risk } & \multicolumn{2}{|c|}{ Carcinogenic Risk ${ }^{b}$} & \multicolumn{2}{|c|}{ Hazard Index ${ }^{b}$} \\
\hline & $\begin{array}{l}\text { Current } \\
\text { Hunter }\end{array}$ & $\begin{array}{l}\text { Future } \\
\text { Child }\end{array}$ & $\begin{array}{l}\text { Current } \\
\text { Hunter }\end{array}$ & $\begin{array}{l}\text { Future } \\
\text { Child }\end{array}$ & $\begin{array}{l}\text { Current } \\
\text { Hunter }\end{array}$ & $\begin{array}{l}\text { Future } \\
\text { Child }\end{array}$ \\
\hline SP-5301 & $2 \times 10^{-6}$ & $1 \times 10^{-5}$ & $4 \times 10^{-7}$ & $3 \times 10^{-6}$ & 0.08 & 0.6 \\
\hline SP-5302 & $2 \times 10^{-6}$ & $9 \times 10^{-6}$ & $5 \times 10^{-7}$ & $4 \times 10^{-6}$ & 0.06 & 0.5 \\
\hline SP-5303 & $1 \times 10^{-6}$ & $5 \times 10^{-6}$ & $7 \times 10^{-7}$ & $5 \times 10^{-6}$ & 0.1 & 0.8 \\
\hline SP-5304 & $1 \times 10^{-6}$ & $4 \times 10^{-6}$ & $4 \times 10^{-7}$ & $4 \times 10^{-6}$ & 0.06 & 0.5 \\
\hline
\end{tabular}

a Dermal exposure to surface water is assumed to be limited because of the small size of springs and ponds in the drainage.

b Chemical carcinogenic risks included all detected carcinogens listed in Table 2 (i.e., 2,4,6-trinitrotoluene, 2,4-dinitrotoluene, 2,6-dinitrotoluene, arsenic, and beryllium). Hazard indexes include all parameters listed in Table 2, except those without available reference dose values (i.e., 2,6-dinitrotoluene, 1,3-dinitrobenzene, 2-amino-4,6-dinitrotoluene, 4-amino-2,6-dinitrotoluene, chloride, cobalt, aluminum, calcium, iron, lead, lithium, magnesium, potassium, sodium, and sulfate). Organic compounds were included only when detected.

\subsubsection{Ecological Risk Considerations}

The BA for the chemical plant area identified the potential for adverse risks to biota from exposure to contaminated media in the Southeast Drainage (DOE 1992). Ecological resources potentially at greatest risk are aquatic biota directly inhabiting surface waters in the drainage and terrestrial biota drinking the surface water. The principal exposure routes to biota are direct (dermal) contact with, and ingestion of, contaminated surface water and sediment. Evaluation of contaminant concentrations in surface water indicated several inorganic contaminants present at levels that may represent an adverse ecological risk to aquatic biota: antimony, cadmium, chromium, lead, mercury, silver, and uranium (Table 7). This determination of potential for ecological risk is based on the ecological effects quotient (EEQ) exceeding a value of 1.0. The EEQ, which is similar to the hazard quotient used to estimate human health risks, is calculated as the ratio of the environmental concentration measured in the field to a benchmark environmental concentration identified as posing no risk to ecological receptors. Benchmark values used to estimate EEQs included ambient water quality criteria (AWQC) for the protection of freshwater aquatic biota (EPA 1986), State of Missouri water quality criteria (Missouri Department of Natural Resources 1992), National Oceanic and Atmospheric Administration (NOAA) screening guidelines (NOAA/Hazmat undated), and no-observed-effect-levels identified in the scientific literature (Parkhurst et al. 1984; Poston et al. 1984). 


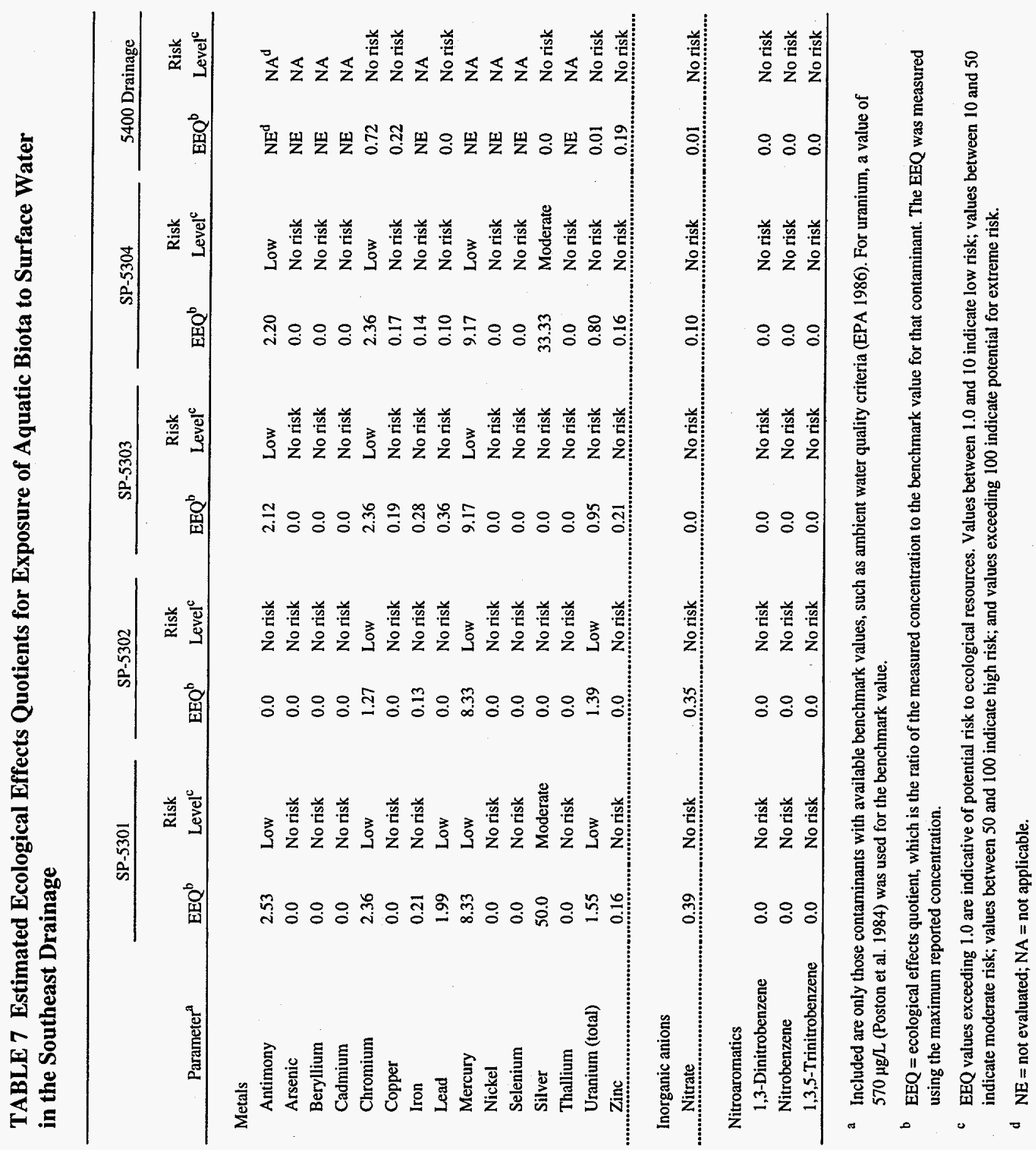


No nitroaromatic compounds were detected in surface waters in the Southeast Drainage at levels that could pose risks to aquatic biota. Similarly, EEQ values were below 1.0 for most of the metals evaluated in surface waters (Table 7). Potential risks $(E E Q>1.0)$ were indicated for antimony, chromium, lead, mercury, silver, and uranium. Risk levels were low for all of these metals except silver, for which a moderate risk was identified. The greatest number of contaminants with risk levels exceeding 1.0 and the single highest risk estimate (EEQ $=50$ for silver) were calculated for spring SP-5301, the uppermost spring sampled in the drainage. Risks were also estimated for several chemicals in surface water from the 5400 background drainage. In contrast to the risks identified for the Southeast Drainage, no EEQ values exceeded 1.0 for any of the metals evaluated in the background drainage (Table 7).

The potential for adverse impacts to aquatic biota was further examined by evaluating the toxicity of surface waters from the Southeast Drainage to a variety of aquatic biota. The toxicity of surface water from springs SP-5303 and SP-5304 was evaluated by using acute and chronic tests and invertebrate and vertebrate test organisms; the results of these tests are summarized in Table 8. No acute toxicity was evident for surface water from either spring location. Chronic toxicity, as indicated by reduced survival of fish (Pimephales), was measured only for surface water collected from spring SP-5303. No reduction in survival was evident for the other biota tested with water from this spring.

TABLE 8 Results of Acute and Chronic Toxicity Testing of Surface Water from the Southeast Drainage and Background 5400 Drainage

Test Results ${ }^{\mathbf{a}}$

5400

Toxicity Test

SP-5303 SP-5304 Drainage ${ }^{b}$

Daphnia 96-hour acute, survival

Hyalella 96-hour acute, survival

Pimephales, 96-hour acute, survival

Xenopus, 96-hour acute, survival

Daphnia 7-day chronic, survival

Hyalella 7-day chronic, survival

Pimephales, 7-day chronic, survival and growth

Xenopus, 7-day chronic, survival and growth

a A minus ( $(-)$ indicates no significant media toxicity $(p>0.05)$; a plus $(+)$ indicates significant media toxicity ( $\mathrm{p} \leq 0.05)$.

b Only SP-5406 was measured. 
In addition to the contaminants in surface water, a number of contaminants have been detected in sediment in the Southeast Drainage (Table 1). Evaluation of the sediment data and estimation of EEQs indicated that nine metals are present in the sediment at concentrations that maypose a risk to ecological resources (Table 9). Ecological effects quotients for sediment were estimated by using the NOAA sediment guidelines developed by Long and Morgan (1990)

Extreme risks to aquatic biota were indicated for exposure to PCBs in sediments from Segments A and C (Table 9). No risks from PCBs were identified for Segment B, and low risks were identified for Segment D. Risks from exposure to metals in the sediment ranged from low for most metals to moderate for silver and high for mercury. No benchmark values were available to estimate risks from sediment-bound uranium or nitroaromatics. Risks were also estimated for sediment from the 5400 background drainage for several of the same metals evaluated in the Southeast Drainage. For these metals, all EEQ values were below 1.0, indicating no risks to aquatic biota (Table 9).

Potential risks to aquatic biota from these contaminants are primarily chemotoxic rather than radiological in nature. The risk assessment conducted for the chemical plant area (DOE 1992) estimated daily radiological doses to freshwater fish in surface water at or near the Weldon Spring site, including the Southeast Drainage. These dose estimates were well below the daily dose limit of $1 \mathrm{rad} / \mathrm{d}$ for protection of aquatic biota as specified in DOE Order 5400.5 ("Radiation Protection of the Public and the Environment").

Risks to terrestrial wildlife were estimated by modeling contaminant uptake via drinking water ingestion for three receptor species: the white-tailed deer, white-footed mouse, and great horned owl. The methods and species exposure factors used for this risk assessment are presented in Appendix B.

Daily contaminant doses were estimated for terrestrial wildlife using the maximum reported concentration of each contaminant detected in surface water in the drainage, and these modeled doses were used to estimate potential risks to the white-tailed deer, white-footed mouse, and the great horned owl. No inorganic contaminants were detected in surface water from the Southeast Drainage at concentrations that could result in daily doses that might pose a risk to terrestrial wildlife drinking from the drainage.

For each receptor, contaminant uptake via the drinking water pathway was very low for most contaminants. Predicted daily contaminant doses were typically less than $0.01 \mathrm{mg} / \mathrm{kg}$ body weight per day, with daily doses of many contaminants less than $0.001 \mathrm{mg} / \mathrm{kg}-\mathrm{d}$ (see Appendix B). Similarly, no risks to terrestrial wildlife were identified for nitroaromatic compounds detected in the surface waters of the drainage. For the inorganic ions and nitroaromatic compounds for which benchmark values were available, the EEQ risk estimates were all less than 0.10 and typically less than 0.001 (Table 10). 
TABLE 9 Estimated Ecological Effects Quotients for Exposure of Aquatic Biota to Sediment in the Southeast Drainage

\begin{tabular}{|c|c|c|c|c|c|c|c|c|c|c|}
\hline \multirow[b]{2}{*}{ Parameter ${ }^{\mathbf{a}}$} & \multicolumn{2}{|c|}{ Segment A } & \multicolumn{2}{|c|}{ Segment B } & \multicolumn{2}{|c|}{ Segment C } & \multicolumn{2}{|c|}{ Segment D } & \multicolumn{2}{|c|}{5400 Drainage } \\
\hline & $\mathrm{EEQ}^{\mathrm{b}}$ & $\begin{array}{c}\text { Risk } \\
\text { Level }^{c}\end{array}$ & $E E Q^{b}$ & $\begin{array}{c}\text { Risk } \\
\text { Level }^{c}\end{array}$ & $\mathrm{EEQ}^{\mathrm{b}}$ & $\begin{array}{c}\text { Risk } \\
\text { Level }^{\mathfrak{c}}\end{array}$ & $\mathrm{EEQ}^{\mathrm{b}}$ & $\begin{array}{c}\text { Risk } \\
\text { Level }^{\mathbf{c}}\end{array}$ & $\mathrm{EEQ}^{\mathrm{b}}$ & $\begin{array}{c}\text { Risk } \\
\text { Level }^{\mathrm{c}}\end{array}$ \\
\hline \multicolumn{11}{|l|}{ Metals } \\
\hline Arsenic & 3.31 & Low & 1.95 & Low & 1.95 & Low & 1.75 & Low & $\mathrm{Ne}^{\mathrm{d}}$ & $\mathrm{NA}^{\mathrm{d}}$ \\
\hline Cadmium & 3.23 & Low & 1.17 & Low & 4.13 & Low & 2.23 & Low & NE & NA \\
\hline Chromium & 2.28 & Low & 0.54 & No risk & 0.94 & No risk & 1.01 & Low & 0.38 & No risk \\
\hline Copper & 5.36 & Low & 0.83 & No risk & 8.88 & Low & 1.94 & Low & 0.59 & No risk \\
\hline Lead & 3.64 & Low & 1.31 & Low & 1.59 & Low & 1.59 & Low & 0.83 & No risk \\
\hline Mercury & 28.62 & Moderate & 3.15 & Low & 12.31 & Moderate & 53.85 & High & $\mathrm{NE}$ & NA \\
\hline Nickel & 2.20 & Low & 1.74 & Low & 4.15 & Low & 1.73 & Low & NE & NA \\
\hline Silver & 14.73 & Moderate & 1.50 & Low & 4.64 & Low & 6.96 & Low & 0.82 & No risk \\
\hline Zinc & 5.08 & Low & 0.71 & No risk & 1.27 & Low & 0.79 & No risk & 0.51 & No risk \\
\hline \multicolumn{11}{|l|}{ PCBs } \\
\hline Total & 132 & Extreme & 0.0 & No risk & 6,600 & Extreme & 2.11 & Low & NE & NA \\
\hline
\end{tabular}

a Included are only those contaminants with available screening values; screening values are from NOAA (Long and Morgan 1990).

b $\mathrm{EEQ}=$ ecological effects quotient, which is the ratio of the measured concentration to the screening value for that contaminant. The EEQ was measured by using the $95 \%$ UCL or the maximum reported concentration if the $95 \%$ UCL exceeded the maximum reported concentration.

c EEQ values exceeding 1.0 are indicative of potential risk to ecological resources. Values between 1.0 and 10 indicate low risk; values between 10 and 50 indicate moderate risk; values between 50 and 100 indicate high risk; and values exceeding 100 indicate potential for extreme risk.

d $\mathrm{NE}=$ not evaluated $\mathrm{NA}=$ not applicable. 
TABLE 10 Estimated Ecological Effects Quotients from the Water Ingestion Pathway for the White-Tailed Deer, White-Footed Mouse, and Great Horned Owl Using the Southeast Drainage

\begin{tabular}{|c|c|c|c|c|c|c|c|}
\hline \multirow{2}{*}{\multicolumn{2}{|c|}{ Contaminant $^{\mathbf{a}}$}} & \multicolumn{2}{|c|}{ White-Tailed Deer } & \multicolumn{2}{|c|}{ White-Footed Mouse } & \multicolumn{2}{|c|}{ Great Horned Owl } \\
\hline & & $\mathrm{EEQ}^{\mathrm{b}}$ & Risk Level & $\mathrm{EEQ}^{\mathrm{b}}$ & Risk Level & $\mathbf{E E Q}^{\mathbf{b}}$ & Risk Level \\
\hline \multicolumn{8}{|c|}{ Metals } \\
\hline & Aluminum & 0.007 & No risk & 0.016 & No risk & $<0.001$ & No risk \\
\hline & Antimony & 0.035 & No risk & 0.079 & No risk & $\mathrm{NB}^{\mathrm{c}}$ & $\mathrm{NA}^{\mathrm{d}}$ \\
\hline & Barium & $<0.001$ & No risk & 0.001 & No risk & $<0.001$ & No risk \\
\hline & Chromium & $<0.001$ & No risk & $<0.001$ & No risk & 0.001 & No risk \\
\hline & Copper & $<0.001$ & No risk & $<0.001$ & No risk & $<0.001$ & No risk \\
\hline & Lead & $<0.001$ & No risk & $<0.001$ & No risk & 0.001 & No risk \\
\hline & Manganese & $<0.001$ & No risk & $<0.001$ & No risk & $<0.001$ & No risk \\
\hline & Molybdenum & $<0.001$ & No risk & 0.021 & No risk & $<0.001$ & No risk \\
\hline & Nickel & $<0.001$ & No risk & $<0.001$ & No risk & $<0.001$ & No risk \\
\hline & Uranium, total & 0.016 & No risk & 0.038 & No risk & 0.003 & No risk \\
\hline & Vanadium & 0.003 & No risk & 0.008 & No risk & $<0.001$ & No risk \\
\hline & Zinc & $<0.001$ & No risk & $<0.001$ & No risk & $<0.001$ & No risk \\
\hline \multicolumn{8}{|c|}{ Inorganic anions } \\
\hline & Nitrate & 0.001 & No risk & 0.003 & No risk & NB & NA \\
\hline \multicolumn{8}{|c|}{ Nitroaromatic compounds } \\
\hline & 1,3,5-Trinitrobenzene & $<0.001$ & No risk & $<0.001$ & No risk & NB & NA \\
\hline & 1,3-Dinitrobenzene & $<0.001$ & No risk & $<0.001$ & No risk & NB & NA \\
\hline & 2,4,6-Trinitrotoluene & 0.003 & No risk & 0.013 & No risk & NB & NA \\
\hline a & $\begin{array}{l}\text { Ecological effects quot } \\
\text { available. }\end{array}$ & Es) wer & culated for & contami & for which & iark value & \\
\hline \multicolumn{8}{|c|}{$\begin{array}{l}\text { bEQ is calculated as the ratio between the predicted applied daily contaminant dose and a "safe" benchmark daily dose } \\
\text { level. EEQ values greater than } 1.0 \text { indicate potential for adverse effects. }\end{array}$} \\
\hline \multicolumn{8}{|c|}{ c $\mathrm{NB}=$ no benchmark value available for calculating the EEQ. } \\
\hline d & NA = not applicable. & & & & & & \\
\hline
\end{tabular}

For this EE/CA, risk reduction for ecological resources is considered to be directly correlated with the reduction of contaminant concentrations or with the removal of contaminated media. As discussed in Section 2.2, the contaminant levels in surface water are expected to decrease, and there should be concomitant reduction in risk to ecological resources.

Currently, it is not known to what extent the contaminated sediment contributes to the contamination of surface water in the drainage or whether the sediment is toxic to aquatic biota. However, the results of the ecological risk assessment indicate that current levels in the sediment and surface water in the drainage pose little or no risk to ecological receptors. The removal of contaminated sediment would remove another potential source of contamination for surface water. 


\subsubsection{Summary}

The risk analysis presented in this EE/CA indicates that on the basis of the current and expected future land use (hunter scenario), sediment and surface water contamination in the Southeast Drainage does not pose an unacceptable risk to human health. For the hypothetical future child scenario, the estimated risks from exposure to sediment and surface water are higher than for the hunter scenario but still within the EPA target risk range of $10^{-6}$ to $10^{-4}$. The potential risk is almost exclusively from radioactive contamination in sediment; the higher risks were calculated for Segments B and C. The heterogeneous distribution of radioactive contamination in the drainage indicates that selective removal of contaminated areas would effectively reduce the resultant risk to a potential receptor in the drainage.

The results of the ecological risk assessment indicate that contaminant levels in surface water in the Southeast Drainage pose no risks to terrestrial biota drinking from the drainage, but surface water and sediment in the Southeast Drainage may pose risks to aquatic biota. However, the risk determinations for aquatic biota must be viewed in context with the results of the surface water toxicity testing, the presence of a diverse amphibian community within the drainage basin, the intermittent nature of surface water flow, and the general absence of permanent aquatic habitats within the drainage.

Although the EEQ values for several contaminants in the surface water within the drainage largely suggest low to moderate risks to aquatic biota, there is little evidence of toxicity of surface water to invertebrates, fish, or amphibians. Biotic surveys of the drainage indicate a rather diverse amphibian community within the drainage. Because of their life-cycle requirements, amphibians inhabiting the drainage likely use spring and pool habitats along the drainage for reproduction; therefore, adults, eggs, and larvae would be directly exposed to contaminants. However, the presence of a diverse amphibian community suggests that the current levels of contamination reported in surface water and sediment from the drainage are not adversely affecting amphibian populations in the drainage.

Biotic surveys also indicate very depauperate aquatic invertebrate and fish communities inhabiting the drainage. Although the existence of these depauperate communities may be due in part to contaminated media, the communities are probably affected more by the intermittent nature of surface water flow and limited habitat availability in the drainage. Fish and invertebrates are largely absent from all but the lowermost portion of the Southeast Drainage because the drainage becomes almost completely dry every year. The greatest number of fish collected from the drainage was obtained near the confluence of the drainage with the Missouri River, where water levels in the river maintain suitable aquatic habitat in the drainage. The fish in this portion of the drainage likely move regularly between the drainage and the river.

The weight of evidence suggests that with the exception of PCBs, the current levels of contamination detected in the surface water and sediment of the Southeast Drainage likely pose little risk to biota in the drainage. Although extreme risks are indicated for PCBs in Segments A and C, 
there is no evidence that aquatic biota are incurring actual impacts, and aquatic biota are probably more affected by natural environmental conditions (low water) than by contaminant levels. Any adverse impacts resulting from contamination within the drainage would be restricted to biota found within the boundaries of the Southeast Drainage basin and would not extend beyond the basin. Because of the limited aquatic communities within the drainage, any risks to the aquatic biota should not be considered ecologically significant and should have no demonstrable effect on the ecological resources of the area. Furthermore, any selective removal of contaminated sediment and ongoing cleanup of contaminant sources at the chemical plant would result in reducing the risks currently posed by the site. 


\section{REMOVAL ACTION OBJECTIVES}

The risk assessment discussed in Chapter 2 does not indicate unacceptable exposure to human health (per the National Oil and Hazardous Substances Pollution Contingency Plan [NCP]) and thus does not indicate a need for further action in the drainage. However, the characterization data indicate localized areas of contamination in sediment, and selective removal of contaminated sediment would provide further protection to a receptor in the drainage. Therefore, DOE is planning to conduct a removal action to reduce the amount of contamination present in the drainage.

\subsection{SCOPE AND PURPOSE}

Implementing the proposed removal action is expected to reduce potential risk to human health and ultimately improve environmental conditions at the drainage. The removal action would address sediment contamination; risk calculations for surface water do not indicate a need for remediation. However, this removal action would also contribute to improving surface water conditions. Sediment removed from the drainage would be transported to a storage area at the chemical plant (e.g. Ash Pond storage area), pending its final disposition into the disposal cell planned for the chemical plant area. Minimization of potential health hazards to personnel performing the removal action and mitigative measures to avoid or minimize impacts to the environment would be incorporated into the planning and design of the removal action. The areas within the drainage included in the removal action would be restored to natural conditions to the extent possible.

\subsection{COMPLIANCE WITH REGULATORY REQUIREMENTS}

Cleanup activities at the Weldon Spring site are conducted in accordance with CERCLA, incorporating the values of NEPA. Values of NEPA relate to the significance of environmental resources. The assessment of the proposed action presented in this EE/CA includes evaluations of potential impacts to the environment and addresses endangered species, floodplains and wetlands, and archaeological and historic resources. Separate evaluations of archaeological and historic resources (Walters 1990a-b) and of wetlands and floodplains (Van Lonkhuyzen and Yin 1996) have been conducted for the Southeast Drainage; this EE/CA incorporates the results of those evaluations. In addition, consultations with the U.S. Fish and Wildlife Service regarding Endangered Species Act issues have been completed (Frazer 1996). The EE/CA also evaluates the potential for impacts to other environmental resources, including fish and wildlife, air quality and noise, and recreation. Thus, NEPA values have been addressed and incorporated into this report to the fullest extent practicable.

Federal regulations require that removal actions shall, to the extent practicable considering the exigencies of the situation, attain applicable or relevant and appropriate requirements (ARARs) 
under federal or state environmental laws or facility siting laws (40 CFR 300.415(i)). Requirements are ARARs only when they pertain to the limited scope to be addressed by the removal action and the specific actions being conducted (Preamble to the NCP; EPA 1990). Once it is determined whether an ARAR is pertinent in scope to the removal action, it must be determined whether compliance is practicable. In determining whether compliance with ARARs is practicable, DOE may consider the urgency of the situation (i.e., with regard to the timing of the proposed removal action) and the scope of the removal action to be conducted.

Under the NCP (EPA 1990), applicable requirements are those cleanup standards; standards of control; and other substantive requirements, criteria, or limitations promulgated under federal environmental or state environmental or facility siting laws that specifically address a hazardous substance, pollutant, contaminant, remedial action, location, or other circumstance found at a site. Relevant and appropriate requirements are those standards, criteria or limitations, and other substantive requirements that are not "applicable" but address problems or situations sufficiently similar to those encountered at the site that their use is well suited to the particular site. Only those state standards that are identified by a state in a timely manner, are uniformly enforced, and are more stringent than federal requirements may be applicable or relevant and appropriate.

In addition to ARARs, other requirements that might be useful for developing the remedy for a site can also be considered as part of the alternatives evaluation. These "to-be-considered requirements" (TBCs) are not promulgated by law and are not enforceable; however, they may be considered if there are no pertinent ARARs. DOE Orders are TBCs. Although they are applicable to all DOE activities under the Atomic Energy Act, they are not formally promulgated and, therefore, cannot be considered ARARs.

Potential ARARs for the proposed removal action are identified on the basis of the nature of the contamination, the location of the proposed activity, and the specific scope of the preferred alternative (see Chapter 6). A list of potential ARARs and TBCs for the proposed action is provided in Appendix C. 


\section{IDENTIFICATION OF REMOVAL ACTION ALTERNATIVES}

\subsection{POTENTIALLY APPLICABLE TECHNOLOGIES}

A general overview of relevant technologies that could be applied to protect human health and the environment at the Southeast Drainage is presented in Sections 4.1.1 through 4.1.4. Response action technologies that are potentially applicable to the proposed action at the drainage include access restrictions, encapsulation, hydraulic removal techniques, and conventional removal techniques. These technologies were screened on the basis of site-specific conditions and the current understanding of contamination at the drainage.

\subsubsection{Access Restrictions}

Access restrictions involve the use of physical barriers, institutional controls, or both to reduce the potential for exposure to contamination present at the drainage. Physical barriers, such as fences, would be relatively easy to implement and would protect human health and the environment. However, fences generally would not be effective in controlling the source or migration of contaminated materials at the drainage, and institutional controls are generally not effective for extended periods in preventing contact with contaminated material. Therefore, fences and institutional controls as access restrictions at the drainage were eliminated from further consideration.

\subsubsection{Concrete Encapsulation}

Concrete encapsulation would involve developing access to contaminated areas to either spray grout or place a concrete mixture over the top of the contaminated sediment. In-situ encapsulation could also be implemented by mixing a portland cement mixture with the contaminated sediment at each contaminated location. Access roads for concrete trucks and placement equipment would be needed. Encapsulation would also require excavation to bedrock around the perimeter of each contaminated location to seal off the concrete to the bedrock (in some locations, excavation would result in almost complete removal of the contaminated material). Although encapsulation might isolate the contaminated material in place, long-term effects of wear and erosion must be considered. Over time, the scouring action of the environment and the natural stream flow through the drainage would undercut the concrete encapsulation. Periodic inspections and repairs would be required. In conclusion, encapsulation would be difficult to implement at the drainage and might not provide a permanent solution; therefore, this technology was eliminated from further consideration. 


\subsubsection{Hydraulic Removal}

Removal by using hydraulic methods would include high-pressure water mobilization of contaminated sediment, with capture and pumping or both, and physical separation of the resulting slurry. Implementing this technique would require a temporary water transmission system along the length of the drainage, construction of one or more capture dams to allow physical separation or slurry pumping, and a system to transport used water back for treatment or disposal. The water transmission system would require a major source of water and a pipeline to the Southeast Drainage.

The hydraulic removal process would be labor and equipment intensive and would result in environmental impacts, such as loss of habitat due to tree and brush removal and potential soil erosion due to the development of equipment access routes (Section 4.1.4). The large volume of high-pressure water required to remove the contaminated sediment might also result in further erosion of the existing drainage and bank instability, particularly because extensive clearing and grubbing would be required to mobilize equipment to the flushing sites. In addition, flushing contaminated sediment through the drainage might result in the spread of contamination into currently uncontaminated areas. Construction of a capture dam or multiple dams would require considerable earthmoving and would potentially create additional environmental impacts to the drainage.

Removal of the contaminated slurries to a water treatment facility would require the installation of pumping facilities and double-walled piping to the chemical plant area or transport of the material in tank trucks from the Katy Trail area. Because the volume of material to be transported would increase by the volume of water and additional uncontaminated soil flushed in the process, the transport costs would be higher than the costs of conventional excavation.

On the basis of these considerations, it was determined that hydraulic removal would be neither environmentally practical nor cost-effective. This technology was therefore eliminated from further consideration.

\subsubsection{Conventional Excavation}

Contaminated sediment could also be removed by conventional construction techniques. This technology has been used extensively and has been effective in removing contamination. In areas of the drainage where large quantities of sediment were to be removed, it would be necessary to remove trees and vegetation, grade the drainage bottom, and develop a haul road surface that could accommodate off-road trucks. In areas where smaller quantities of sediment were to be removed, vegetation would have to be removed to accommodate multiple trips for tracked vehicles to transport the sediment to a staging area for loading into off-road trucks. Removal of larger quantities of sediment would require more extensive clearing of the access routes and drainage bottoms. Root balls that would be removed from clean areas for temporary haul road construction and trees that fell on clean soil would be removed from the immediate excavation and haul road 
areas. These materials would be left in the drainage to provide wildlife habitat to the extent possible. Conventional excavation could accelerate erosion in the drainage and increase turbidity in the storm runoff, and the potential for increased erosion and turbidity would exist until trees and other vegetation could reestablish and stabilize the soil exposed by the excavations. The upper portions of the drainage would be more sensitive to this type of damage than the lower portions because the upper area is steeper and narrower.

Because the conventional excavation technology is considered relatively cost-effective and easy to implement, it was retained for further analysis.

\subsection{IDENTIFICATION OF PRELIMINARY REMOVAL ACTION ALTERNATIVES}

The preliminary screening of potentially applicable technologies resulted in the identification of two alternatives: no action and conventional excavation. To further explore the feasibility of conventional excavation and to aid in evaluating alternatives, two subalternatives were identified according to several factors: available routes and access, engineering methodology, degree of environmental damage that would be caused by removing trees and vegetation in the drainage to access the contaminated sediment locations, cost, and potential risk reduction. Within each of the four delineated segments, areas potentially targeted for removal by excavation were identified as those locations exceeding a total radiological risk of $1 \times 10^{-5}$ for a hypothetical child scenario (see Appendix A).

The removal action alternatives identified for evaluation in Chapter 5 of this EE/CA may be summarized as follows:

- Alternative 1: No Action; and

- Alternative 2: Conventional Excavation

- Subalternative 2.1: Conventional excavation at selected locations within the drainage using existing cleared right-of-way routes and access.

- Subalternative 2.2: Conventional excavation at all targeted locations throughout the drainage via new off-road access and a haul route through the drainage.

Subalternative 2.1 would involve removal of selected areas in all segments of the drainage. A temporary haul road would be constructed from Katy Trail to provide access to the lower portion of Segment D (Figure 3). Selected locations in Segment C, lower Segment B, and portions of Segment A would be accessed with tracked vehicles on existing right-of-way corridors. 


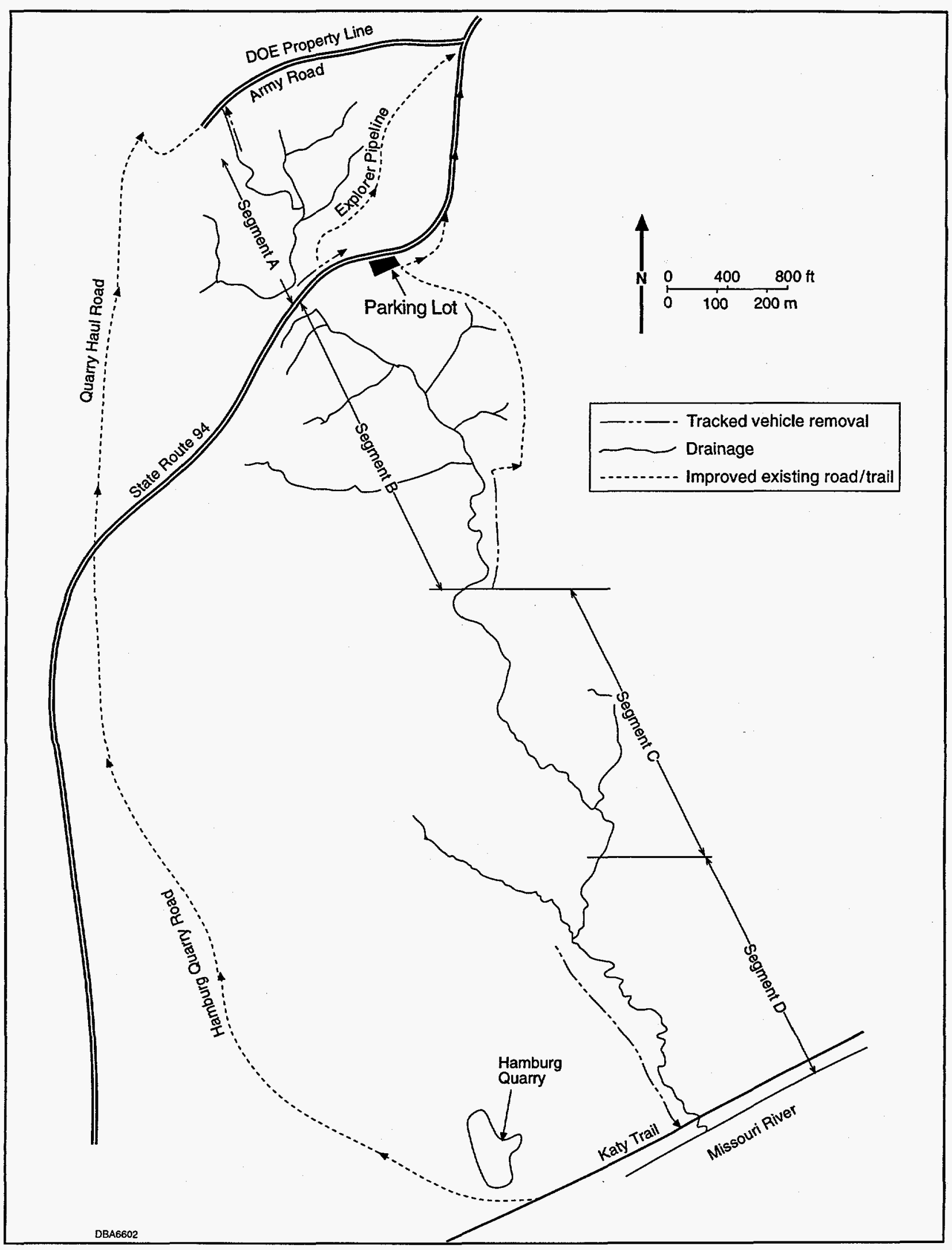

FIGURE 3 Haul Route for Subalternative 2.1 
Subalternative 2.2 would involve removing all targeted sediment locations and would employ an alternate haul route. Access to Segments B, C, and D would be obtained by constructing a temporary off-road access route at the north end of Segment B (Figure 4). This upper access route would eliminate the need for using Katy Trail but would require a staging and decontamination area in the Missouri Department of Conservation parking area located south of State Route 94. This subalternative would also require extensive clearing and tree removal for a new haul route through the entire length of the drainage. 


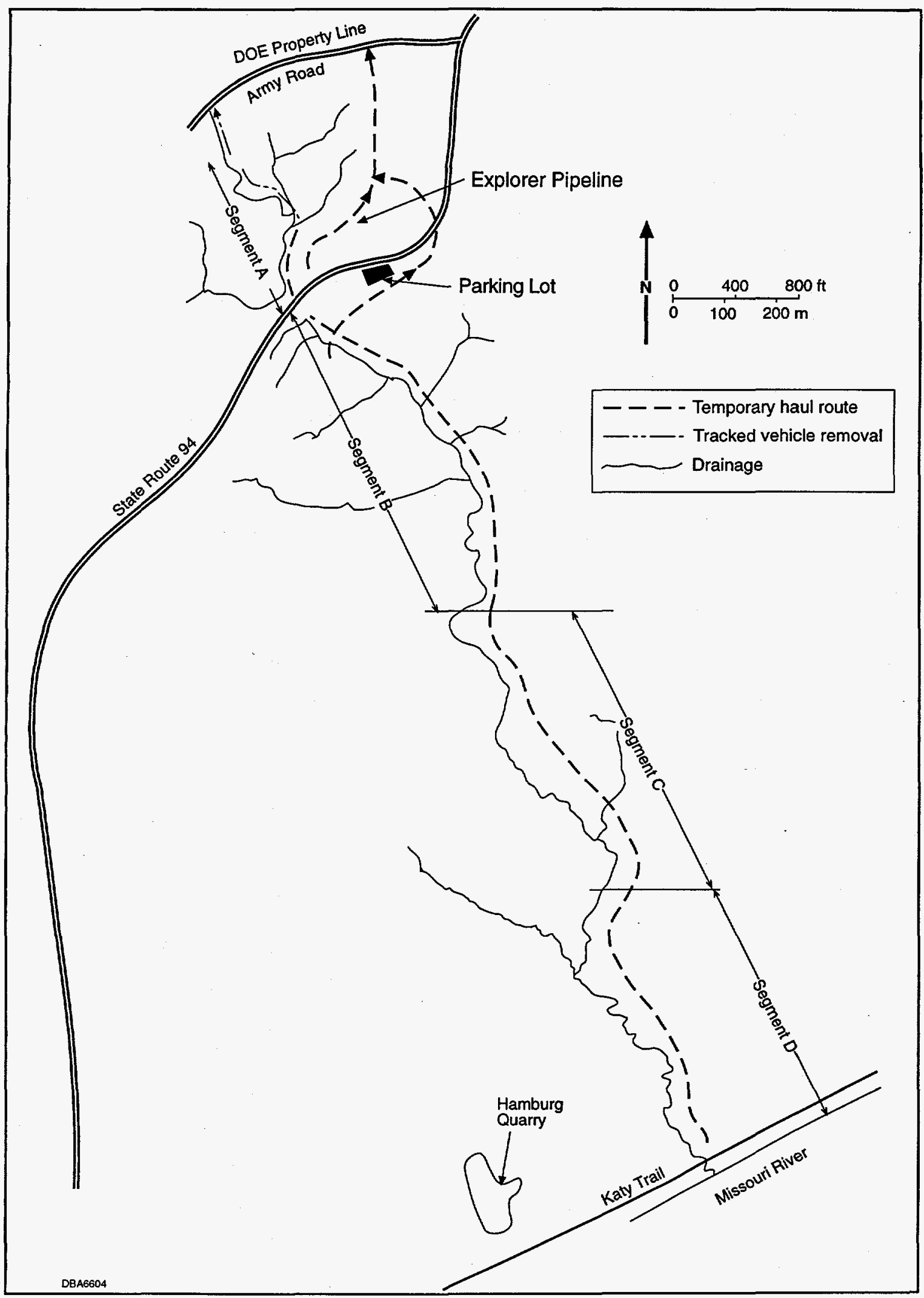

FIGURE 4 Haul Route for Subalternative 2.2 


\section{ANALYSIS OF ALTERNATIVES}

\subsection{DESCRIPTION OF POTENTIAL ALTERNATIVES}

The potential alternatives for remediation of the Southeast Drainage were assessed in terms of effectiveness and implementability. The effectiveness of an alternative is defined in terms of ensuring protection of and minimizing impacts to human health and the environment. The implementability of an alternative is defined by its technical feasibility, availability, administrative feasibility, and cost. Both action alternatives were determined to use technologies that are feasible and available; therefore, the discussion of alternatives in Section 5.1.2 is limited to effectiveness, cost, and administrative feasibility. The conventional excavation and transportation activities that would occur under each subalternative are described, and the potential impacts of these activities are identified. However, the process of detailed design and negotiations with state and local agencies to obtain necessary permits might require modifications to the conceptual designs presented here (e.g., haul routes or work sequence). These potential modifications would not change the underlying relative costs, order-of-magnitude costs, general environmental impacts, or implementability issues applicable to this removal action.

\subsubsection{No-Action Alternative}

The No-Action Alternative (Alternative 1) would involve no change in current exposures to elevated levels of radioactivity in sediment. Potential human health impacts from existing contaminant levels in the drainage were estimated to be within the acceptable risk range (per the NCP) for current and hypothetical future land use. No direct environmental impacts would be expected to occur, although contaminated sediment would remain in the drainage and continue to pose a potential slight risk to aquatic ecological resources and potentially affect surface water quality in the drainage. However, there is no evidence that current levels of contamination are adversely affecting ecological resources in the drainage. Technical feasibility and availability do not apply to the No-Action Alternative.

\subsubsection{Alternative 2: Conventional Excavation}

\subsubsection{Subalternative 2.1: Conventional Excavation at Selected Locations within the Drainage Using Existing Cleared Right-of-Way Routes and Katy Trail Access}

Subalternative 2.1 involves excavating selected locations exceeding a risk of $1 \times 10^{-5}$ for the child scenario that are accessible via existing routes and right-of-way corridors to access the upper drainage, whereas the lower drainage would be accessed from the south end via Katy Trail 
(Figure 3). This subalternative would use tracked loaders to haul material from the lower portion of Segment D to a staging and decontamination area near Katy Trail. The materials would then be transported along the Katy Trail to the Hamburg Quarry road, crossing State Route 94 to the DOE quarry haul road. Areas in the central portion of the drainage would be accessed from the cleared powerline right-of-way with tracked vehicles. Excavated material would first be transported out of the drainage via the cleared road at the top of the hill above the powerline right-of-way and then to the Army road via State Route 94. Contamination in the lower portion of Segment A would be accessed by the Explorer Pipeline right-of-way; excavated materials would be transported to the chemical plant area by the Army road. Access to the upper portion of Segment A would be directly from the Army road with tracked vehicles and off-road trucks. Use of these routes would result in minimal disruption of the mature, high-quality forest community that exists in the drainage.

Selective removal of contaminated areas in these segments would, in effect, reduce significantly the potential for future human health risks. The post-remediation risks to a hypothetical future child who visited the drainage would be less than $1 \times 10^{-5}$ in the areas that were remediated and would not exceed $1 \times 10^{-4}$ at any unremediated location. Potential environmental impacts for this alternative would include (1) fugitive dust emissions and increases in ambient noise levels during excavation and hauling activities, (2) transport of sediment downstream through the drainage during sediment excavation, (3) minimal temporary loss of vegetation and wildlife habitat due to clearing of existing right-of-way corridors and excavation requirements in the flow channel, and (4) disruption of recreational use of Katy Trail during some phases of implementation. An off-road vehicle crossing of State Route 94 would be needed to access the DOE quarry haul road in the area west of the drainage and short-term use of a small segment of State Route 94 east of the drainage.

Air quality and noise impacts could disturb ecological resources and recreational activities in the vicinity of the excavation activities and along haul routes. However, these impacts would be minor and temporary. Although some mature trees may be impacted under this subalternative, overall impacts to the high-quality forest community would be minimal. Most of the vegetation clearing activities would occur in previously disturbed right-of-way corridors that are largely vegetated with invasive, non-native herbaceous and shrubby species. Minor, long-term positive environmental impacts would result from a reduction in environmental contaminant levels and thus a reduction in direct exposure of wildlife to contaminants.

Administrative feasibility for Subalternative 2.1 would require an access permit from the state agencies to the drainage and Katy Trail. An additional permit would also be required to cross and use limited portions of State Route 94 . The cost to implement this alternative is estimated to be about $\$ 450 / \mathrm{m}^{3}\left(\$ 595 / \mathrm{yd}^{3}\right)$. The total cost is estimated to be $\$ 1,148,000$. 


\subsubsection{Subalternative 2.2: Conventional Excavation of All Targeted Locations within the Drainage via New Off-Road Access and a Haul Route through the Drainage}

Subalternative 2.2 would involve excavation of all locations exceeding a risk of $1 \times 10^{-5}$ for the child scenario. These locations would be accessed by construction of a temporary haul route through the entire length of the drainage. Sediment removed from Segments B, C, and D would be transported out of the drainage on a temporary haul route constructed through the woods in the upper portion of Segment B (Figure 4). This upper drainage route would eliminate the need for using Katy Trail, and the staging and decontamination area would be located near the parking area south of State Route 94 rather than near the trail. Construction of the haul route connecting Segment B with the chemical plant area would require removing additional trees and vegetation on the drainage side slope, on a new route south of State Route 94, and on the route north of State Route 94 connecting with the existing Army road (see Figure 4). This removal would result in extensive, long-term disruption of the forest community in the drainage. Clearing activities required in Segments $A$ and $B$ of the drainage would increase the potential for erosion. An off-road vehicle crossing of State Route 94, east of the drainage, would be needed to implement this subalternative.

Access into Segment A would require construction of a haul route that follows the existing grade into the upper end of the drainage. The haul route would include the Army road on the south side of the chemical plant area. Access into the central portion of Segment A would require additional clearing and tree removal to access and remove the contaminated sediment. Contamination in the lower portion of Segment A would be accessed using the Explorer Pipeline right-of-way; excavated material would be transported to the chemical plant area using a newly constructed haul route from the Explorer Pipeline to the Army Road.

Potential reduction in human health risk associated with Subalternative 2.2 would result in a post-remediation risk of less than $1 \times 10^{-5}$ for the child scenario at all locations. Major environmental impacts from implementing this alternative would be incurred as a result of access road construction, vegetation clearing, and drainage flowline disruption from excavation activities. Segment A has an average flowline grade of $2.5 \%$, compared with 1.3 to $1.9 \%$ for the lower portions of the drainage. Because of the steepness of the drainage in Segment A, the potential for soil erosion is greater along the access route and at the excavation areas within this segment. Construction of the access route would result in extensive, long-term disturbance and loss of high-quality forest vegetation and wildlife habitat.

Administrative feasibility for Subalternative 2.2 is the same as for Subalternative 2.1. The cost to implement this alternative is estimated to be about $\$ 1,088 / \mathrm{m}^{3}\left(\$ 831 / \mathrm{yd} \mathrm{d}^{3}\right)$, at a total cost of $\$ 3,077,000$.

\subsection{COMPARATIVE ANALYSIS OF REMOVAL ALTERNATIVES}

The alternatives discussed in Section 5.1 were compared according to their effectiveness, implementability, and cost. This comparison is summarized in Table 11. 
TABLE 11 Comparative Analysis of Removal Action Alternatives

\begin{tabular}{|c|c|c|c|c|}
\hline \multirow[b]{2}{*}{ Alternative } & \multicolumn{2}{|c|}{ Effectiveness } & \multicolumn{2}{|c|}{ Implementability } \\
\hline & Health Impacts & Environmental Impacts & Administrative Feasibility & Cost \\
\hline 1 & $\begin{array}{l}\text { No change. Potential risk is } \\
\text { acceptable under reasonable land- } \\
\text { use scenario. }\end{array}$ & $\begin{array}{l}\text { No direct impact. Contaminated } \\
\text { sediment would have the potential to } \\
\text { migrate and disperse. }\end{array}$ & Acceptable. & No direct cost. \\
\hline 2.1 & $\begin{array}{l}\text { Would reduce potential risk to a } \\
\text { hypothetical child receptor to less } \\
\text { than } 1 \times 10^{-5} \text { in areas remediated; } \\
\text { the risk to this hypothetical } \\
\text { receptor would not exceed } 1 \times 10^{-4} \\
\text { at any unremediated location. }\end{array}$ & $\begin{array}{l}\text { Temporary low to moderate impacts } \\
\text { from construction and excavation } \\
\text { activities to air quality, noise, and } \\
\text { recreational activities. Minor long- } \\
\text { term impacts to vegetation and } \\
\text { wildlife habitat, largely restricted to } \\
\text { currently disturbed areas along } \\
\text { existing right-of-way corridors. } \\
\text { Some loss of mature trees, but } \\
\text { numbers limited. }\end{array}$ & $\begin{array}{l}\text { Would require access permit to } \\
\text { drainage and Katy Trail and } \\
\text { permit to cross and use portions } \\
\text { of State Route } 94 \text {. }\end{array}$ & Total cost, $\$ 1,148,000 ; \$ 595 / \mathrm{yd}^{3}$ \\
\hline 2.2 & $\begin{array}{l}\text { Would reduce potential risk to a } \\
\text { hypothetical child receptor to less } \\
\text { than } 1 \times 10^{-5} \text { at all locations. }\end{array}$ & $\begin{array}{l}\text { Moderate but temporary impacts } \\
\text { from construction and excavation } \\
\text { activities to air quality, noise, and } \\
\text { recreational activities; major long- } \\
\text { term impacts to forest vegetation } \\
\text { and wildlife habitat. Permanent loss } \\
\text { of a large number of mature, old } \\
\text { trees resulting in large-scale } \\
\text { disruption of the forest community. } \\
\text { Environmental damage would be } \\
\text { high, and the area impacted would } \\
\text { extend throughout the drainage. }\end{array}$ & $\begin{array}{l}\text { Would require permits for } \\
\text { crossing State Route } 94 \text {, for road } \\
\text { construction, and for use of the } \\
\text { parking lot. }\end{array}$ & Total cost, $\$ 3,077,000 ; \$ 831 / \mathrm{yd}^{3}$. \\
\hline
\end{tabular}




\section{PROPOSED ACTION}

On the basis of the discussion and comparison presented in Chapter 5, Subalternative 2.1 was identified as the preferred alternative. This alternative could be implemented in a cost-effective manner and is protective of human health and the environment while minimizing environmental impacts. Implementing Subalternative 2.1 (as described in Section 5.1.2.1) would be contingent upon DOE's ability to obtain the necessary access agreements. Slight variations in the proposed haul routes might occur if these agreements were not in place within the time frame necessary for implementation of the action. Implementation of the proposed action is expected to begin as early as the winter of 1997.

Under the proposed action, selected contaminated sediment in accessible areas of the drainage would be removed with track-mounted equipment and transported by off-road haul trucks. The locations targeted for excavation are shown in Figure 5. Access would be from the south end of Katy Trail, from an existing powerline right-of-way in the center and from temporary previously disturbed off-road routes to the north and south ends of Segment A. Excavated materials would be stored temporarily at an on-site storage area (e.g., Ash Pond storage area or material staging area), with final disposal in the planned engineered disposal cell for the Weldon Spring site. On the basis of stability testing previously performed for related wastes, the waste material from the excavations would not be treated before disposal (MK-Ferguson Company 1993).

Implementing the proposed action would require use of four minimal-access routes capable of supporting off-road haul trucks at slow speed. It is anticipated that all of these routes could be constructed without additional clearing and minimal upgrade. These routes are described in Section 5.1.2.1 and illustrated in Figure 3. Because of the relatively temporary duration of this action, it is anticipated that the only surface improvement to the routes used by the trucks would be the addition of a layer of white to light gray aggregate after initial clearing and grading in some areas and in the staging areas where trucks would be loaded by the track excavators. The primary purpose of this surface material would be to identify contaminated soil spillage for survey and cleanup, if necessary. After this material was no longer required for contamination tracking control, it would be removed from those portions of the staging areas or routes that would be revegetated and then transported to the chemical plant area for reuse or disposal.

The characterization data indicate that the estimated excavation depth would typically be 0.6 to $0.9 \mathrm{~m}$ ( 2 to $3 \mathrm{ft}$ ) below the surface. In no case would excavation proceed below bedrock, which exists at depths approximately 0.9 to $2.4 \mathrm{~m}$ ( 3 to $8 \mathrm{ft}$ ) below the surface. The sediment would be excavated with track-mounted loaders, the buckets would be covered with tarps at the excavation site, and the excavated material would be hauled out of the drainage to the haul trucks at the staging areas; multiple trips would be made by the track loaders to avoid road building in the drainage. The material would be hauled to the site from the staging areas in off-road trucks. This type of truck would provide off-road capabilities and minimize transport spillage because it does not have a tailgate. 


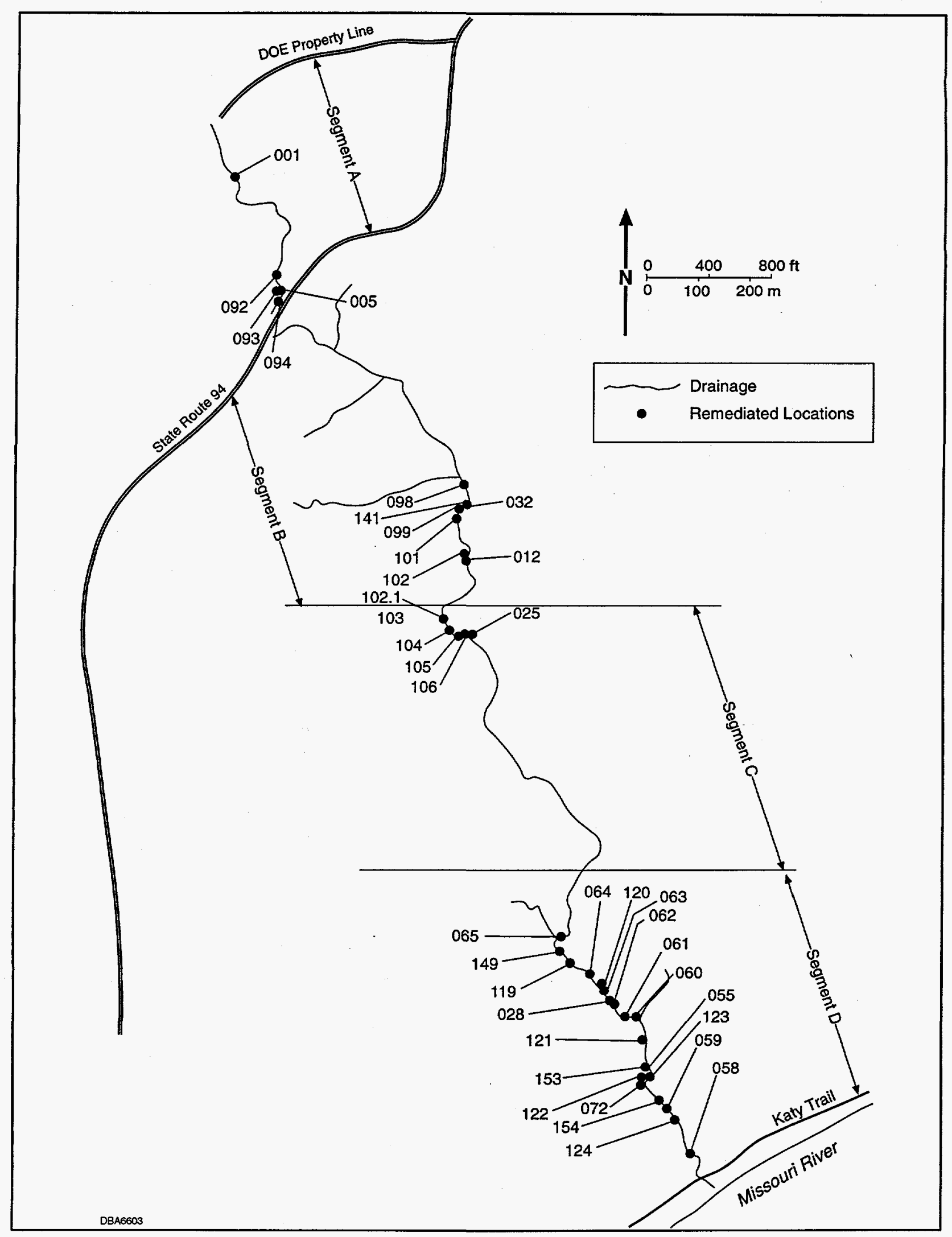

FIGURE 5 Locations Targeted for Remediation under the Proposed Action 
At a minimum, the following controls would be maintained during hauling operations:

- All parts of the haul route would be sprayed with water (from trucks) to minimize airborne dust.

- All loads would be covered. A crew would be stationed near the beginning of the haul routes to cover and secure the haul trucks. Similar crews would be stationed to cover and secure the track excavators.

- A motor grader would be required for continual maintenance of haul roads.

- Traffic control would be provided along State Route 94. Flaggers with radios would be stationed at key points.

- Temporary berming would be constructed in areas where excavation was taking place adjacent to the flow channel. The berms would prevent stormwater runoff from the excavation to flowing in the channel.

- Temporary channel relocation and berming would be constructed in areas where excavation was taking place in the existing channel to bypass stream flow and major storm-water runoff away from the excavation and to protect the excavation from flooding and erosion.

- Erosion controls would be installed downgradient of all excavations to prevent the transport of silt down the drainage by minor storm-water runoff flowing out of the excavations.

- Restoration in areas outside of the drainage channel would include reshaping access routes and staging areas. These areas would be mulched and seeded.

- Restoration of excavation areas within the drainage would include grading to avoid steep or vertical slope, with minimal backfilling. For stabilization, erosion controls would be left at the downstream extent of these areas until natural vegetation was reestablished.

- Plans addressing sediment and erosion control (including applicable permit applications) would be submitted for approval by the proper authorities (e.g., St. Charles County Highway Engineer).

- Surface water quality would be monitored during the removal action.

To guide cleanup activities, risk-based cleanup criteria for principal radioactive contaminants were derived for a corresponding risk level of $1 \times 10^{-5}$ for the hypothetical child scenario. 
These risk-based concentrations were calculated by combining the appropriate intake and risk equations for the exposure pathways identified for the hypothetical child scenario (see Section 2.3 and Table 3). The calculated risk-based cleanup criteria are as follows: radium-226, $13 \mathrm{pCi} / \mathrm{g}$; radium-228, $13 \mathrm{pCi} / \mathrm{g}$; thorium-230, $350 \mathrm{pCi} / \mathrm{g}$; and uranium-238, $290 \mathrm{pCi} / \mathrm{g}$. The concentration limit for uranium-238 includes the contribution from uranium-234, and the level for radium-228 includes the contribution from thorium-228. Confirmation activities (including sampling) would be carried out to ensure that levels remaining in each remediated area after cleanup were at or below the $1 \times 10^{-5}$ risk level for the hypothetical child scenario. For comparison, the equivalent risk-based cleanup criteria for each radionuclide for the hunter scenario are $60 \mathrm{pCi} / \mathrm{g}$ for both radium-228 and radium-226, 1,600 pCi/g for thorium-230, and 1,300 pCi/g for uranium-238. 


\section{REFERENCES}

Bair, F.E., 1992, The Weather Almanac, 6th ed., Gale Research Inc., Detroit, Mich.

Bethel, W.M., et al., 1993, Small Mammal Population Analysis for the Weldon Spring Site Remedial Action Project, prepared by Lindenwood College, St. Charles, Mo., for U.S. Department of Energy, Oak Ridge Field Office, Oak Ridge, Tenn., May.

Black, P., and D. Carlson, 1996, memorandum from Black and Carlson (Neptune and Company, Inc., Los Alamos, N.M.), to M. Picel (Argonne National Laboratory, Argonne, Ill.), Aug.

Boerner, A.J., 1986, Radiological Survey of the August A. Busch and Weldon Spring Wildlife Areas, Weldon Spring Site, St. Charles County, Missouri, Final Report, prepared by Oak Ridge Associated Universities, Oak Ridge, Tenn., for U.S. Department of Energy, April.

Deming, D.J., 1986, Radiological Survey, U.S. Army Reserve Property, Weldon Spring Site, St. Charles County, Missouri, Final Report, prepared by Oak Ridge Associated Universities, Oak Ridge, Tenn., for U.S. Department of Energy, Jan.

DOE: see U.S. Department of Energy.

Environmental Science \& Engineering, Inc., 1993, Weldon Spring Remedial Action Project 1992 Aquatic Biological Monitoring - WP305, ESE No. 592-1043-0400, Final Report, prepared for MK-Ferguson Company, St. Charles, Mo., April.

EPA: see U.S. Environmental Protection Agency.

Frazer, G.D., 1996, letter from Frazer (U.S. Fish and Wildlife Service, Columbia Field Office, Columbia, Mo.) to J.S. Van Fossen (U.S. Department of Energy, Oak Ridge Operations, Weldon Spring Site., St. Charles, Mo.), July 29.

IT Corporation, 1992, Final Remedial Investigation Report, Weldon Spring Ordnance Works RI/FS, Weldon Spring, Missouri, Project No. 312071, prepared for Department of the Army, Corps of Engineers, Kansas City District, Nov.

Long, E.R., and L.G. Morgan, 1990, Potential for Biological Effects of Sediment-Sorbed Contaminants Tested in the National Status and Trends Program, NOAA Technical Memorandum NOS OMA 52, National Ocean Service, National Oceanic and Atmospheric Administration, Seattle, Wash.

Missouri Department of Conservation, 1989, Area Management Plan for the August A. Busch Complex, Jefferson City, Mo. 
Missouri Department of Conservation, 1989, Area Management Plan for the August A. Busch Complex, Jefferson City, Mo.

Missouri Department of Natural Resources, 1991, Shallow Groundwater Investigations at Weldon Spring, Missouri: Final Report for Fiscal Years 1988-1990, prepared by Division of Geology and Land Survey, Rolla, Mo., for U.S. Department of Energy, Weldon Spring Site Remedial Action Project, St. Charles, Mo., June.

Missouri Department of Natural Resources, 1992, Rules of Department of Natural Resources: Division 20 - Clean Water Commission; Chapter 7 - Water Quality, Code of State Regulations 10 CSR 20-7.031 (Water Quality Standards), Jefferson City, Mo.

MK-Ferguson Company, 1993, Final Report for the Investigation, Sampling, and Characterization of Sediments/Sludges within the Chemical Plant Process Sewers, inter-office correspondence from E. Dowell to E.C. 2.1.13, April 13.

MK-Ferguson Company and Jacobs Engineering Group, 1989, Characterization of Chemical and Radiological Contamination in Lake and Stream Sediments on Properties Surrounding the Weldon Spring Site, DOE/OR/21548-060, prepared for U.S. Department of Energy, Oak Ridge Operations Office, Weldon Spring Site Remedial Action Project, St. Charles, Mo., Aug.

MK-Ferguson Company and Jacobs Engineering Group, 1995, Southeast Drainage Items, interoffice correspondence from K. Warbritton to distribution, June 22.

MK-Ferguson Company and Jacobs Engineering Group, 1996, Southeast Drainage Soils Review Sampling Report, DOE/OR/21548-559, Revision 1A, prepared for U.S. Department of Energy, Oak Ridge Operations Office, Weldon Spring Site Remedial Action Project, St. Charles, Mo., July.

Nash, T., 1990, letter from Nash (U.S. Fish and Wildlife Service, Columbia Field Office, Columbia, Mo.) to I. Hlohowskyj (Argonne National Laboratory, Argonne, Ill.) with enclosures, May 9

National Oceanic and Atmospheric Administration/Hazmat, undated, NOAA Screening Guidelines for Organics and Inorganics; NOAA Quick Screening Reference Cards, NOAA/Hazmat, Seattle, Wash.

NOAA: see National Oceanic and Atmospheric Administration.

Parkhurst, B.J., et al., 1984, "An Environmental Hazard Evaluation of Uranium in a Rocky Mountain Stream," Environmental Toxicology and Chemistry 3:113-124.

Poston, T.M., et al., 1984, "Toxicity of Uranium to Daphnia magna," Water, Air, and Soil Pollution 22:289-298. 
Reitinger, J., 1995, memorandum from Reitinger (MK-Ferguson Company, St. Charles, Mo.) to H. Hartmann (Argonne National Laboratory, Argonne, Ill.) describing May 1995 sediment sampling near Springs 5303 and 5304.

Tieger, J., 1988, letter from Tieger (Field Supervisor, U.S. Fish and Wildlife Service, Columbia Field Office, Columbia, Mo.) to I. Hlohowskyj (Argonne National Laboratory, Argonne, Ill.), Dec. 22.

U.S. Department of Energy, 1992, Baseline Assessment of the Chemical Plant Area of the Weldon Spring Site, DOE/ER/21548-091, prepared by Argonne National Laboratory, Argonne, Ill., for U.S. Department of Energy, Oak Ridge Field Office, Oak Ridge, Tenn., Nov.

U.S. Department of Energy, 1995a, Sampling Plan for the Remedial Investigation/Feasibility Study for the Groundwater Operable Units at the Chemical Plant Area and at the Ordnance Works Area, Weldon Spring, Missouri (Appendix to the Work Plan), DOE/OR/21548-445, Rev. 1, prepared by MK-Ferguson Company and Jacobs Engineering Group, St. Charles, Missouri, for the U.S. Department of Energy, Oak Ridge Operations Office, Weldon Spring Site Remedial Action Project, July.

U.S. Department of Energy, 1995b, Work Plan for the Remedial Investigation/Feasibility Study for the Groundwater Operable Units at the Chemical Plant Area and the Ordnance Works Area, Weldon Spring, Missouri, DOE/OR/21548-567, prepared by Argonne National Laboratory, Argonne, Ill., for U.S. Department of Energy, Oak Ridge Operations Office, Weldon Spring Site Remedial Action Project, Weldon Spring, Mo., Aug.

U.S. Environmental Protection Agency, 1986, Quality Criteria for Water 1986, EPA 440/5-86-001, Office of Water Regulations and Standards, Washington, D.C., May.

U.S. Environmental Protection Agency, 1989, Risk Assessment Guidance for Superfund, Volume I: Human Health Evaluation Manual (Part A), EPA/540/1-89/002, Interim Final, Office of Emergency and Remedial Response, Washington, D.C., Dec.

U.S. Environmental Protection Agency, 1990, "National Oil and Hazardous Substances Pollution Contingency Plan; Final Rule (40 CFR Part 300),” Federal Register 55(46):8666-8895, March 8.

U.S. Environmental Protection Agency, 1992, Dermal Exposure Assessment: Principles and Applications, EPA/600/8-91/011B, Interim Report, Office of Research and Development, Washington, D.C., Jan.

U.S. Environmental Protection Agency, 1994, Health Effects Assessment Summary Tables, FY-1994 Annual, EPA 540/R-94/020, Office of Solid Waste and Emergency Response, Washington, D.C., March. 
U.S. Environmental Protection Agency, 1995, Integrated Risk Information System, Office of Research and Development, database, accessed Jan.

Van Lonkhuyzen, R., and S. Yin, 1996, Floodplain/Wetlands Assessment for Remediation of the Southeast Drainage at the Weldon Spring Site, Weldon Spring, Missouri, ANL/EAD/TM-64, Argonne National Laboratory, Argonne, Ill., Aug.

Walters, G.R., 1990a, A Phase I Survey and Evaluation of the Southeast Drainage of the Weldon Spring Remedial Action Project Area, St. Charles County, Missouri, prepared by Triad Research Services, Columbia, Mo., for U.S. Department of Energy and Argonne National Laboratory, Argonne, Ill., July 20.

Walters, G.R., 1990b, letter from Walters (Triad Research Services, Columbia, Mo.) to L. Malinowski (Argonne National Laboratory, Argonne, Ill.), Aug. 13. 
APPENDIX A:

LOCATION-SPECIFIC RISK CALCULATIONS FOR RADIOACTIVE CONTAMINANTS 


\section{APPENDIX A:}

\section{LOCATION-SPECIFIC RISK CALCULATIONS FOR RADIOACTIVE CONTAMINANTS}

\section{A.1 METHODOLOGY}

The doses associated with intake of radioactive contaminants resulting from incidental ingestion of sediment were calculated as follows:

$$
D_{i}=R_{i} \times I R \times E F \times E D \times F I \times D C F i
$$

where:

$$
\begin{aligned}
D_{i}= & \text { dose from radionuclide } \mathrm{i}(\mathrm{mrem}) ; \\
\mathrm{R}_{\mathrm{i}}= & \underset{\mathrm{pCi} / \mathrm{L})}{\text { radionuclide concentration in sediment or surface water }(\mathrm{pCi} / \mathrm{g} \text { or }} \\
\mathrm{IR}= & \text { sediment or surface water ingestion rate (g/event or L/event); } \\
\mathrm{EF} & =\text { exposure frequency (events/yr); } \\
\mathrm{ED} & =\text { exposure duration }(\mathrm{yr}) ; \\
\mathrm{FI} & =\text { fraction ingested from elevated areas (unitless); and } \\
\mathrm{DCF}_{\mathrm{i}} & =\text { ingestion dose conversion factor for radionuclide } \mathrm{i}(\mathrm{mrem} / \mathrm{pCi}) .
\end{aligned}
$$

The doses from the external radiation pathway were calculated by using the methodology from the DOE residual radioactive material (RESRAD) computer code (Yu et al. 1993). Dose was calculated as follows:

$$
D_{i}=R_{s i} \times E F \times E D \times A \times F \times D C F=x t
$$

where:

$$
\begin{aligned}
\mathrm{A}= & \text { area factor for radionuclide } \mathrm{i} \text { (unitless); } \\
\mathrm{F}= & \text { fraction of time spent in contaminated area (unitless); and } \\
\mathrm{DCF}_{\mathrm{ext}}= & \text { external gamma dose conversion factor for radionuclide i } \\
& {[(\mathrm{mrem} / \mathrm{h}) /(\mathrm{pCi} / \mathrm{g})] . }
\end{aligned}
$$


The $\mathrm{DCF}_{\text {ext }}$ factors are based on the assumption that the radionuclides are uniformly distributed in the soil, extending to an infinite depth and to an infinite lateral extent. Because contamination in the drainage is heterogeneous, site-specific information was incorporated into the calculations. An area factor was calculated for each radionuclide of concern using an updated methodology incorporated into RESRAD; a source radius of $2 \mathrm{~m}$ and a depth of $1 \mathrm{~m}$ were used as input. It was also assumed that only $25 \%$ of the exposure time was spent in areas with elevated radionuclide concentrations because a receptor would be likely to move around the drainage. Dose conversion factors for the ingestion and external gamma irradiation pathway are provided in Table A.1, along with the site-specific area factors for each radionuclide.

\section{A.2 LOCATION-SPECIFIC CALCULATIONS}

Location-specific calculations were performed to estimate the total radiological risk associated with each sampling location in the drainage. The results are presented in Table A.2. The purpose of these calculations is to focus engineering design for removal of sediment in the drainage. The methodology and exposure parameters used to calculate radiological health risks are provided in Sections 2.3 and A.1 of this engineering evaluation/cost analysis (EE/CA). The exposure point concentration for each location is an average of the surface ( 0 to $15-\mathrm{cm}$ depth) and subsurface samples for each radionuclide.

\section{A.3 POSTCLEANUP RISK CALCULATIONS}

Postcleanup radiological risk reduction calculations were also performed for Subalternatives 2.1 and 2.2. Both alternatives involve the application of the conventional excavation technology discussed in Chapter 4. Subalternative 2.1 involves excavation of selective locations that exceed a risk of $1 \times 10^{-5}$ for the child scenario and that are accessible via existing routes and right-of-way corridors, and Subalternative 2.2 involves removal of all locations in the drainage that exceed a risk of $1 \times 10^{-5}$. Risk reduction calculations were performed for each segment under each alternative. The locations potentially targeted for removal are those locations in which the total risk exceeds $1 \times 10^{-5}$, as shown in Table A.2. Risk calculations for each segment were based on the one-tailed $95 \%$ upper confidence limit of the arithmetic average (UCL), assuming that locations exceeding $1 \times 10^{-5}$ risk would be remediated. The UCL was calculated assuming that remediated locations were equal to two times background soil concentrations for each radionuclide (DOE 1992). The postremedial risks for the current hunter scenario are presented in Table A.3, and those for the hypothetical child scenario are presented in Table A.4 
TABLE A.1 Dose Conversion Factors and Area Factors for the External Gamma Irradiation and Ingestion Pathways ${ }^{\mathrm{a}}$

\begin{tabular}{lcccc} 
& & & \multicolumn{2}{c}{ Ingestion $^{\mathrm{e}}$} \\
\cline { 4 - 5 } & $\begin{array}{c}\text { External Gamma } \\
\text { Irradiation }\end{array}$ & & \multicolumn{1}{c}{${ }^{\mathrm{D}}$} \\
Radionuclide & {$[(\mathrm{mrem} / \mathrm{h}) /(\mathrm{pCi} / \mathrm{g})]$} & Area Factor $^{\mathrm{c}}$ & $\mathrm{f}_{1}^{\mathrm{d}}$ & $\begin{array}{c}\mathrm{DCF} \\
(\mathrm{mrem} / \mathrm{pCi})\end{array}$ \\
\hline Lead-210 & $7.0 \times 10^{-7}$ & 0.575 & $2 \times 10^{-1}$ & $6.7 \times 10^{-3}$ \\
Radium-226 & $1.3 \times 10^{-3}$ & 0.555 & $2 \times 10^{-1}$ & $1.1 \times 10^{-3}$ \\
Radium-228 & $6.8 \times 10^{-4}$ & 0.546 & $2 \times 10^{-1}$ & $1.2 \times 10^{-3}$ \\
Thorium-228 & $1.2 \times 10^{-3}$ & 0.530 & $2 \times 10^{-4}$ & $7.5 \times 10^{-4}$ \\
Thorium-230 & $1.4 \times 10^{-7}$ & 0.858 & $2 \times 10^{-4}$ & $5.3 \times 10^{-4}$ \\
Uranium-234 & $4.6 \times 10^{-8}$ & 0.858 & $5 \times 10^{-2}$ & $2.6 \times 10^{-4}$ \\
& & & $2 \times 10^{-3}$ & $2.5 \times 10^{-5}$ \\
& $1.6 \times 10^{-5}$ & 0.858 & $5 \times 10^{-2}$ & $2.5 \times 10^{-4}$ \\
Uranium-238 & & & $2 \times 10^{-3}$ & $3.8 \times 10^{-5}$ \\
\hline
\end{tabular}

a In this assessment, the radiation doses associated with thorium-228, lead-210, and uranium-234 are included with those reported for radium-228, radium-226, and uranium-238, respectively. Thus, the DCF for radium-228 is the sum of that for radium-228 plus thorium-228, the DCF for uranium-238 is the sum of that for uranium-238 plus uranium-234, and the DCF for radium-226 is the sum of that for radium-226 plus lead-210. (See Section 2.3.2.1 of the Baseline Assessment for the chemical plant area [DOE 1992]).

b Source: Eckerman and Ryman (1993).

c Site-specific; derived for a contaminated radius of $2 \mathrm{~m}$ and depth of $1 \mathrm{~m}$.

d Fraction of a stable element entering the gastrointestinal tract that reaches body fluids.

e Source: Yu et al. (1993). 
TABLE A.2 Location-Specific Calculations for the Hypothetical Future Child Scenario

\begin{tabular}{|c|c|c|c|c|c|c|c|c|}
\hline \multirow{3}{*}{$\begin{array}{c}\text { Exposure } \\
\text { Unit }\end{array}$} & \multirow{3}{*}{$\begin{array}{c}\text { Sample } \\
\text { ID }\end{array}$} & \multirow{2}{*}{\multicolumn{4}{|c|}{ Concentration $(\mathrm{pCi} / \mathrm{g})$}} & \multicolumn{3}{|c|}{ Total Risk } \\
\hline & & & & & & \multirow[b]{2}{*}{ Ingestion } & \multirow{2}{*}{$\begin{array}{l}\text { External } \\
\text { Gamma } \\
\end{array}$} & \multirow[b]{2}{*}{ Cumulative } \\
\hline & & Uranium-238 & Radium-226 & Radium-228 & Thorium-230 & & & \\
\hline A & $001 \mathrm{~A}$ & 240 & 93 & 9.2 & 49 & $4.7 \times 10^{-5}$ & $4.3 \times 10^{-5}$ & $9.0 \times 10^{-5}$ \\
\hline A & $001 \mathrm{~B}$ & 79 & 18 & 3.9 & 4.2 & $1.0 \times 10^{-5}$ & $1.0 \times 10^{-5}$ & $2.0 \times 10^{-5}$ \\
\hline $\mathrm{A}$ & 002 & 120 & 39 & 5.0 & 15 & $2.0 \times 10^{-5}$ & $1.9 \times 10^{-5}$ & $3.9 \times 10^{-5}$ \\
\hline A & 003 & 200 & 39 & 1.4 & 31 & $2.3 \times 10^{-5}$ & $1.7 \times 10^{-5}$ & $4.0 \times 10^{-5}$ \\
\hline A & 004 & 50 & 17 & 2.7 & 11 & $9.2 \times 10^{-6}$ & $8.6 \times 10^{-6}$ & $1.8 \times 10^{-5}$ \\
\hline A & $005 \mathrm{~A}$ & 160 & 16 & 190 & 72 & $3.3 \times 10^{-5}$ & $1.3 \times 10^{-4}$ & $1.6 \times 10^{-4}$ \\
\hline A & $005 \mathrm{~B}$ & 180 & 21 & 180 & 300 & $4.0 \times 10^{-5}$ & $1.2 \times 10^{-4}$ & $1.6 \times 10^{-4}$ \\
\hline $\mathrm{A}$ & $005 \mathrm{C}$ & 210 & 12 & 120 & 130 & $2.6 \times 10^{-5}$ & $8.0 \times 10^{-5}$ & $1.6 \times 10^{-4}$ \\
\hline $\mathrm{A}$ & 016 & 17 & 7.0 & 1.5 & 14 & $4.0 \times 10^{-6}$ & $3.7 \times 10^{-6}$ & $7.7 \times 10^{-6}$ \\
\hline A & 017 & 15 & 11 & 1.4 & 1.4 & $5.1 \times 10^{-6}$ & $5.0 \times 10^{-6}$ & $1.0 \times 10^{-5}$ \\
\hline A & 018 & 16 & 1.3 & 0.8 & 0.2 & $1.1 \times 10^{-6}$ & $1.1 \times 10^{-6}$ & $2.2 \times 10^{-6}$ \\
\hline A & 087 & 47 & 15 & 0.64 & 6.8 & $8.0 \times 10^{-6}$ & $6.5 \times 10^{-6}$ & $1.4 \times 10^{-5}$ \\
\hline A & 088 & 43 & 30 & 2.8 & 11 & $1.4 \times 10^{-5}$ & $1.3 \times 10^{-5}$ & $2.8 \times 10^{-5}$ \\
\hline A & 089 & 31 & 11 & 1.3 & 5.1 & $5.8 \times 10^{-6}$ & $5.3 \times 10^{-6}$ & $1.1 \times 10^{-5}$ \\
\hline A & 090 & 48 & 33 & 1.3 & 14 & $1.6 \times 10^{-5}$ & $1.4 \times 10^{-5}$ & $2.9 \times 10^{-5}$ \\
\hline $\mathrm{A}$ & 091 & 29 & 22 & 1.2 & 14 & $1.1 \times 10^{-5}$ & $9.4 \times 10^{-6}$ & $2.0 \times 10^{-5}$ \\
\hline A & 092 & 64 & 24 & 1.5 & 67 & $1.4 \times 10^{-5}$ & $1.0 \times 10^{-5}$ & $2.4 \times 10^{-5}$ \\
\hline A & 093 & 67 & 17 & 6.6 & 72 & $1.2 \times 10^{-5}$ & $1.1 \times 10^{-5}$ & $2.3 \times 10^{-5}$ \\
\hline A & 094 & 25 & 8.1 & 3.2 & 23 & $5.1 \times 10^{-6}$ & $5.3 \times 10^{-6}$ & $1.0 \times 10^{-5}$ \\
\hline B & 006 & 56 & 25 & 2.8 & 18 & $1.3 \times 10^{-5}$ & $1.2 \times 10^{-5}$ & $2.5 \times 10^{-5}$ \\
\hline B & 007 & 49 & 12 & 4.0 & 11 & $7.2 \times 10^{-6}$ & $7.5 \times 10^{-6}$ & $1.5 \times 10^{-5}$ \\
\hline B & 008 & 17 & 36 & 1.5 & 12 & $1.6 \times 10^{-5}$ & $1.5 \times 10^{-5}$ & $3.1 \times 10^{-5}$ \\
\hline B & 009 & 59 & 110 & 1.7 & 13 & $4.9 \times 10^{-5}$ & $4.3 \times 10^{-5}$ & $9.2 \times 10^{-5}$ \\
\hline B & 010 & 17 & 21 & 2.2 & 13 & $9.7 \times 10^{-6}$ & $9.3 \times 10^{-6}$ & $1.9 \times 10^{-5}$ \\
\hline
\end{tabular}


TABLE A.2 (Cont.)

\begin{tabular}{|c|c|c|c|c|c|c|c|c|}
\hline \multirow{3}{*}{$\begin{array}{c}\text { Exposure } \\
\text { Unit } \\
\end{array}$} & \multirow{3}{*}{$\begin{array}{c}\text { Sample } \\
\text { ID }\end{array}$} & \multirow{2}{*}{\multicolumn{4}{|c|}{ Concentration $(\mathrm{pCi} / \mathrm{g})$}} & \multicolumn{3}{|c|}{ Total Risk } \\
\hline & & & & & & \multirow[b]{2}{*}{ Ingestion } & \multirow{2}{*}{$\begin{array}{l}\text { External } \\
\text { Gamma }\end{array}$} & \multirow[b]{2}{*}{ Cumulative } \\
\hline & & Uranium-238 & Radium-226 & Radium-228 & Thorium-230 & & & \\
\hline B & 011 & 2.6 & 1.3 & 0.74 & 0.27 & $7.2 \times 10^{-7}$ & $1.0 \times 10^{-6}$ & $1.7 \times 10^{-6}$ \\
\hline B & 012 & 52 & 42 & 1.6 & 12 & $2.0 \times 10^{-5}$ & $1.7 \times 10^{-5}$ & $3.7 \times 10^{-5}$ \\
\hline B & 019 & 7.8 & 18 & 1.1 & 7.5 & $8.3 \times 10^{-6}$ & $7.7 \times 10^{-6}$ & $1.6 \times 10^{-5}$ \\
\hline B & 020 . & 2.6 & 1.2 & 0.87 & 3.0 & $7.4 \times 10^{-7}$ & $1.0 \times 10^{-6}$ & $1.8 \times 10^{-6}$ \\
\hline B & 021 & 14 & 2.2 & 1.0 & 2.8 & $1.5 \times 10^{-6}$ & $1.6 \times 10^{-6}$ & $3.0 \times 10^{-6}$ \\
\hline B & 132 & 57 & 100 & 3.1 & 960 & $7.2 \times 10^{-5}$ & $4.1 \times 10^{-5}$ & $1.1 \times 10^{-4}$ \\
\hline B & 095 & 16 & 4.6 & 1.5 & 6.8 & $2.7 \times 10^{-6}$ & $2.8 \times 10^{-6}$ & $5.5 \times 10^{-6}$ \\
\hline B & 096 & 27 & 11 & 1.7 & 12 & $5.8 \times 10^{-6}$ & $5.3 \times 10^{-6}$ & $1.1 \times 10^{-5}$ \\
\hline B & 098 & 120 & 180 & 3.4 & 4,900 & $2.2 \times 10^{-4}$ & $7.0 \times 10^{-5}$ & $2.9 \times 10^{-4}$ \\
\hline B & 099 & 39 & 53 & 3.7 & 170 & $2.9 \times 10^{-5}$ & $2.3 \times 10^{-5}$ & $5.1 \times 10^{-5}$ \\
\hline B & 101 & 64 & 170 & 13 & 1,400 & $1.2 \times 10^{-4}$ & $7.3 \times 10^{-5}$ & $1.9 \times 10^{-4}$ \\
\hline B & 102 & 17 & 19 & 3.1 & 31 & $9.7 \times 10^{-6}$ & $9.3 \times 10^{-6}$ & $1.9 \times 10^{-5}$ \\
\hline $\mathrm{C}$ & 025 & 640 & 280 & 1.7 & 320 & $1.5 \times 10^{-4}$ & $1.1 \times 10^{-4}$ & $2.6 \times 10^{-4}$ \\
\hline $\mathrm{C}$ & 027 & 79 & 7.2 & 21 & 19 & $7.8 \times 10^{-6}$ & $1.7 \times 10^{-5}$ & $2.4 \times 10^{-5}$ \\
\hline $\mathrm{C}$ & 049 & 26 & 6.5 & 1.7 & 12 & $4.0 \times 10^{-6}$ & $3.7 \times 10^{-6}$ & $7.7 \times 10^{-6}$ \\
\hline $\mathrm{C}$ & 102.1 & 140 & 82 & 4.8 & 370 & $5.0 \times 10^{-5}$ & $3.5 \times 10^{-5}$ & $8.5 \times 10^{-5}$ \\
\hline $\mathrm{C}$ & 103 & 330 & 26 & 2.9 & 44 & $2.1 \times 10^{-5}$ & $1.4 \times 10^{-5}$ & $3.5 \times 10^{-5}$ \\
\hline $\mathrm{C}$ & 104 & 32 & 120 & 2.4 & 56 & $5.2 \times 10^{-5}$ & $4.6 \times 10^{-5}$ & $9.7 \times 10^{-5}$ \\
\hline $\mathrm{C}$ & 105 & 35 & 26 & 11 & 21 & $1.4 \times 10^{-5}$ & $1.7 \times 10^{-5}$ & $3.1 \times 10^{-5}$ \\
\hline $\mathrm{C}$ & 106 & 62 & 63 & 6.0 & 54 & $3.0 \times 10^{-5}$ & $2.8 \times 10^{-5}$ & $5.9 \times 10^{-5}$ \\
\hline $\mathrm{C}$ & 107 & 58 & 35 & 2.2 & 120 & $2.0 \times 10^{-5}$ & $1.5 \times 10^{-5}$ & $3.5 \times 10^{-5}$ \\
\hline $\mathrm{C}$ & 108 & 27 & 24 & 5.0 & 16 & $1.2 \times 10^{-5}$ & $1.2 \times 10^{-5}$ & $2.4 \times 10^{-5}$ \\
\hline $\mathrm{C}$ & 108.1 & 24 & 35 & 2.3 & 20 & $1.6 \times 10^{-5}$ & $1.5 \times 10^{-5}$ & $3.1 \times 10^{-5}$ \\
\hline
\end{tabular}


TABLE A.2 (Cont.)

\begin{tabular}{|c|c|c|c|c|c|c|c|c|}
\hline \multirow{3}{*}{$\begin{array}{c}\text { Exposure } \\
\text { Unit }\end{array}$} & \multirow{3}{*}{$\begin{array}{c}\text { Sample } \\
\text { ID }\end{array}$} & \multirow{2}{*}{\multicolumn{4}{|c|}{ Concentration $(\mathrm{pCi} / \mathrm{g})$}} & \multicolumn{3}{|c|}{ Total Risk } \\
\hline & & & & & & \multirow[b]{2}{*}{ Ingestion } & \multirow{2}{*}{$\begin{array}{l}\text { External } \\
\text { Gamma }\end{array}$} & \multirow[b]{2}{*}{ Cumulative } \\
\hline & & Uranium-238 & Radium-226 & Radium-228 & Thorium-230 & & & \\
\hline $\mathrm{C}$ & 110 & 98 & 34 & 2.7 & 32 & $1.8 \times 10^{-5}$ & $1.5 \times 10^{-5}$ & $3.4 \times 10^{-5}$ \\
\hline $\mathrm{C}$ & 110.1 & 38 & 11 & 2.7 & 22 & $6.6 \times 10^{-6}$ & $6.2 \times 10^{-6}$ & $1.3 \times 10^{-5}$ \\
\hline $\mathrm{C}$ & 111 & 65 & 43 & 6.1 & 48 & $2.2 \times 10^{-5}$ & $2.1 \times 10^{-5}$ & $4.2 \times 10^{-5}$ \\
\hline $\mathrm{C}$ & 112 & 55 & 70 & 2.5 & 1,700 & $7.9 \times 10^{-5}$ & $2.9 \times 10^{-5}$ & $1.1 \times 10^{-4}$ \\
\hline $\mathrm{C}$ & 113 & 68 & 66 & 2.9 & 56 & $3.2 \times 10^{-5}$ & $2.7 \times 10^{-5}$ & $5.9 \times 10^{-5}$ \\
\hline $\mathrm{C}$ & 114 & 22 & 22 & 3.9 & 21 & $1.1 \times 10^{-5}$ & $1.1 \times 10^{-5}$ & $2.2 \times 10^{-5}$ \\
\hline $\mathrm{C}$ & 115 & 47 & 56 & 2.8 & 36 & $2.6 \times 10^{-5}$ & $2.4 \times 10^{-5}$ & $5.0 \times 10^{-5}$ \\
\hline $\mathrm{C}$ & 116 & 34 & 18 & 3.8 & 23 & $9.5 \times 10^{-6}$ & $9.5 \times 10^{-6}$ & $1.9 \times 10^{-5}$ \\
\hline $\mathrm{C}$ & 143 & 3.7 & 1.8 & 1.6 & 4.6 & $1.2 \times 10^{-6}$ & $1.8 \times 10^{-6}$ & $2.9 \times 10^{-6}$ \\
\hline $\mathrm{C}$ & 144 & 1.4 & 1.1 & 1.5 & 2.4 & $7.1 \times 10^{-7}$ & $1.4 \times 10^{-6}$ & $2.1 \times 10^{-6}$ \\
\hline $\mathrm{C}$ & 145 & 2.3 & 1.3 & 0.9 & 4.6 & $8.4 \times 10^{-7}$ & $1.1 \times 10^{-6}$ & $1.9 \times 10^{-6}$ \\
\hline $\mathrm{C}$ & 146 & 1.3 & 1.4 & 2.6 & 1.7 & $9.4 \times 10^{-7}$ & $2.2 \times 10^{-6}$ & $3.1 \times 10^{-6}$ \\
\hline D & $026 \mathrm{~A}$ & 11 & 4.5 & 1.4 & 24 & $3.0 \times 10^{-6}$ & $2.7 \times 10^{-6}$ & $5.7 \times 10^{-6}$ \\
\hline $\mathrm{D}$ & 026B & 14 & 5.1 & 1.9 & 240 & $9.7 \times 10^{-6}$ & $3.2 \times 10^{-6}$ & $1.3 \times 10^{-5}$ \\
\hline $\mathrm{D}$ & $026 \mathrm{C}$ & 5.7 & 1.3 & 1.09 & 22 & $1.4 \times 10^{-6}$ & $1.2 \times 10^{-6}$ & $2.7 \times 10^{-6}$ \\
\hline $\mathrm{D}$ & 028 & 79 & 22 & 8.8 & 34 & $1.3 \times 10^{-5}$ & $1.5 \times 10^{-5}$ & $2.8 \times 10^{-5}$ \\
\hline $\mathrm{D}$ & 030 & 2.9 & 2.4 & 1.4 & 6.5 & $1.4 \times 10^{-6}$ & $1.9 \times 10^{-6}$ & $3.3 \times 10^{-6}$ \\
\hline $\mathrm{D}$ & 050 & 7.7 & 9.3 & 1.0 & 6.8 & $4.4 \times 10^{-6}$ & $4.2 \times 10^{-6}$ & $8.6 \times 10^{-6}$ \\
\hline $\mathrm{D}$ & 051 & 33 & 8.2 & 3.2 & 120 & $8.1 \times 10^{-6}$ & $5.4 \times 10^{-6}$ & $1.3 \times 10^{-5}$ \\
\hline D & 052 & 5.7 & 1.9 & 1.3 & 4.3 & $1.2 \times 10^{-6}$ & $1.6 \times 10^{-6}$ & $2.8 \times 10^{-6}$ \\
\hline $\mathrm{D}$ & 053 & 23 & 5.6 & 1.2 & 8.9 & $3.4 \times 10^{-6}$ & $3.1 \times 10^{-6}$ & $6.5 \times 10^{-6}$ \\
\hline $\mathrm{D}$ & 054 & 3.3 & 2.1 & 1.2 & 4.1 & $1.2 \times 10^{-6}$ & $1.6 \times 10^{-6}$ & $2.8 \times 10^{-6}$ \\
\hline$D$ & 055 & 45 & 17 & 1.7 & 47 & $9.9 \times 10^{-6}$ & $7.8 \times 10^{-6}$ & $1.8 \times 10^{-5}$ \\
\hline $\mathrm{D}$ & 056 & 16 & 3.9 & 1.3 & 11 & $2.6 \times 10^{-6}$ & $2.5 \times 10^{-6}$ & $5.0 \times 10^{-6}$ \\
\hline
\end{tabular}


TABLE A.2 (Cont.)

\begin{tabular}{|c|c|c|c|c|c|c|c|c|}
\hline \multirow{3}{*}{$\begin{array}{c}\text { Exposure } \\
\text { Unit } \\
\end{array}$} & \multirow{3}{*}{$\begin{array}{c}\text { Sample } \\
\text { ID }\end{array}$} & \multirow{2}{*}{\multicolumn{4}{|c|}{ Concentration (pCi/g) }} & \multicolumn{3}{|c|}{ Total Risk } \\
\hline & & & & & & \multirow[b]{2}{*}{ Ingestion } & \multirow{2}{*}{$\begin{array}{l}\text { External } \\
\text { Gamma } \\
\end{array}$} & \multirow[b]{2}{*}{ Cumulative } \\
\hline & & Uranium-238 & Radium-226 & Radium-228 & Thorium-230 & & & \\
\hline $\mathrm{D}$ & 057 & 3.6 & 2.7 & 1.3 & 3.8 & $1.5 \times 10^{-6}$ & $1.9 \times 10^{-6}$ & $3.4 \times 10^{-6}$ \\
\hline $\mathrm{D}$ & 058 & 81 & 54 & 3.6 & 64 & $2.7 \times 10^{-5}$ & $2.4 \times 10^{-5}$ & $5.1 \times 10^{-5}$ \\
\hline D & 059 & 130 & 54 & 2.5 & 160 & $3.1 \times 10^{-5}$ & $2.3 \times 10^{-5}$ & $5.4 \times 10^{-5}$ \\
\hline $\mathrm{D}$ & 060 & 25 & 65 & 1.2 & 28 & $2.9 \times 10^{-5}$ & $7.5 \times 10^{-5}$ & $5.4 \times 10^{-5}$ \\
\hline $\mathrm{D}$ & 061 & 270 & 76 & 2.5 & 100 & $4.4 \times 10^{-5}$ & $3.2 \times 10^{-5}$ & $7.5 \times 10^{-5}$ \\
\hline $\mathrm{D}$ & 062 & 27 & 14 & 2.3 & 11 & $7.2 \times 10^{-6}$ & $7.0 \times 10^{-6}$ & $1.4 \times 10^{-5}$ \\
\hline $\mathrm{D}$ & 063 & 110 & 48 & 3.3 & 81 & $2.6 \times 10^{-5}$ & $2.1 \times 10^{-5}$ & $4.7 \times 10^{-5}$ \\
\hline $\mathrm{D}$ & 064 & 60 & 20 & 3.1 & 65 & $1.2 \times 10^{-5}$ & $1.0 \times 10^{-5}$ & $2.3 \times 10^{-5}$ \\
\hline $\mathrm{D}$ & 065 & 200 & 39 & 19 & 150 & $2.8 \times 10^{-5}$ & $2.8 \times 10^{-5}$ & $5.7 \times 10^{-5}$ \\
\hline $\mathrm{D}$ & 066 & 200 & 38 & 4.3 & 320 & $3.1 \times 10^{-5}$ & $1.9 \times 10^{-5}$ & $5.0 \times 10^{-5}$ \\
\hline $\mathrm{D}$ & 067 & 150 & 30 & 3.5 & 44 & $1.8 \times 10^{-5}$ & $1.5 \times 10^{-5}$ & $3.3 \times 10^{-5}$ \\
\hline D & 068 & 120 & 23 & 86 & 160 & $2.7 \times 10^{-5}$ & $6.5 \times 10^{-5}$ & $9.2 \times 10^{-5}$ \\
\hline $\mathrm{D}$ & 069 & 4.1 & 1.5 & 1.3 & 2.9 & $9.5 \times 10^{-7}$ & $1.5 \times 10^{-6}$ & $2.4 \times 10^{-6}$ \\
\hline $\mathrm{D}$ & 070 & 6.4 & 3.6 & 1.3 & 15 & $2.2 \times 10^{-6}$ & $2.3 \times 10^{-6}$ & $4.5 \times 10^{-6}$ \\
\hline $\mathrm{D}$ & 071 & 5.5 & 1.6 & 1.1 & 3.6 & $1.0 \times 10^{-6}$ & $1.4 \times 10^{-6}$ & $2.4 \times 10^{-6}$ \\
\hline $\mathrm{D}$ & 072 & 20 & 9.0 & 1.9 & 16 & $5.0 \times 10^{-6}$ & $4.8 \times 10^{-6}$ & $9.8 \times 10^{-6}$ \\
\hline $\mathrm{D}$ & 073 & 3.8 & 1.5 & 1.0 & 3.3 & $9.2 \times 10^{-7}$ & $1.2 \times 10^{-6}$ & $2.1 \times 10^{-6}$ \\
\hline $\mathrm{D}$ & 074 & 4.2 & 1.5 & 1.1 & 2.7 & $9.5 \times 10^{-7}$ & $1.3 \times 10^{-6}$ & $2.3 \times 10^{-6}$ \\
\hline $\mathrm{D}$ & 117 & 120 & 99 & 5.8 & 54 & $4.7 \times 10^{-5}$ & $4.2 \times 10^{-5}$ & $8.9 \times 10^{-5}$ \\
\hline $\mathrm{D}$ & 118 & 77 & 19 & 2.9 & 48 & $1.2 \times 10^{-5}$ & $9.5 \times 10^{-6}$ & $2.1 \times 10^{-5}$ \\
\hline $\mathrm{D}$ & 119 & 65 & 20 & 3.6 & 18 & $1.1 \times 10^{-5}$ & $1.0 \times 10^{-5}$ & $2.2 \times 10^{-5}$ \\
\hline $\mathrm{D}$ & 120 & 180 & 100 & 8.1 & 84 & $5.1 \times 10^{-5}$ & $4.5 \times 10^{-5}$ & $9.5 \times 10^{-5}$ \\
\hline D & 121 & 30 & 25 & 2.6 & 23 & $1.2 \times 10^{-5}$ & $1.2 \times 10^{-5}$ & $2.4 \times 10^{-5}$ \\
\hline $\mathrm{D}$ & 122 & 15 & 35 & 3.1 & 43 & $1.7 \times 10^{-5}$ & $1.5 \times 10^{-5}$ & $3.2 \times 10^{-5}$ \\
\hline
\end{tabular}


TABLE A.2 (Cont.)

\begin{tabular}{|c|c|c|c|c|c|c|c|c|}
\hline \multirow{3}{*}{$\begin{array}{c}\text { Exposure } \\
\text { Unit } \\
\end{array}$} & \multirow{3}{*}{$\begin{array}{c}\text { Sample } \\
\text { ID }\end{array}$} & \multirow{2}{*}{\multicolumn{4}{|c|}{ Concentration $(\mathrm{pCi} / \mathrm{g})$}} & \multicolumn{3}{|c|}{ Total Risk } \\
\hline & & & & & & \multirow[b]{2}{*}{ Ingestion } & \multirow{2}{*}{$\begin{array}{c}\text { External } \\
\text { Gamma } \\
\end{array}$} & \multirow[b]{2}{*}{ Cumulative } \\
\hline & & Uranium-238 & Radium-226 & Radium-228 & Thorium-230 & & & \\
\hline D & 123 & 86 & 50 & 7.1 & 67 & $2.6 \times 10^{-5}$ & $2.4 \times 10^{-5}$ & $5.1 \times 10^{-5}$ \\
\hline $\mathrm{D}$ & 124 & 76 & 75 & 3.1 & 2,700 & $1.1 \times 10^{-4}$ & $3.1 \times 10^{-5}$ & $1.4 \times 10^{-4}$ \\
\hline $\mathrm{D}$ & 147 & 2.9 & 1.6 & 3.3 & 4.0 & $1.2 \times 10^{-6}$ & $2.7 \times 10^{-5}$ & $4.0 \times 10^{-6}$ \\
\hline D & 148 & 2.2 & 1.1 & 2.6 & 3.2 & $8.7 \times 10^{-7}$ & $2.1 \times 10^{-6}$ & $3.0 \times 10^{-6}$ \\
\hline $\mathrm{D}$ & 149 & 19 & 21 & 1.3 & 9.2 & $9.6 \times 10^{-6}$ & $8.8 \times 10^{-6}$ & $1.8 \times 10^{-5}$ \\
\hline $\mathrm{D}$ & 150 & 11 & 3.3 & 1.9 & 9.1 & $2.1 \times 10^{-6}$ & $2.6 \times 10^{-6}$ & $4.7 \times 10^{-6}$ \\
\hline D & 151 & 14 & 5.3 & 2.9 & 12 & $3.2 \times 10^{-6}$ & $4.0 \times 10^{-6}$ & $7.2 \times 10^{-6}$ \\
\hline $\mathrm{D}$ & 152 & 6.2 & 3.8 & 2.6 & 3.1 & $2.1 \times 10^{-6}$ & $3.1 \times 10^{-6}$ & $5.2 \times 10^{-6}$ \\
\hline D & 153 & 10 & 8.6 & 2.1 & 11 & $4.4 \times 10^{-6}$ & $4.7 \times 10^{-6}$ & $9.1 \times 10^{-6}$ \\
\hline D & 154 & 13 & 3.3 & 2.0 & 12 & $2.3 \times 10^{-6}$ & $2.6 \times 10^{-6}$ & $4.9 \times 10^{-6}$ \\
\hline
\end{tabular}

a Sample numbers designated with a letter (A, B, C) denote collocated samples collected in the same general vicinity. 
TABLE A.3 Radiological Risk Reduction Calculations for the Current Hunter ${ }^{a}$

Carcinogenic Risk per Segment

\begin{tabular}{ccccc} 
Alternative & A & B & C & D \\
\hline Baseline & $1 \times 10^{-5}$ & $2 \times 10^{-5}$ & $2 \times 10^{-5}$ & $1 \times 10^{-5}$ \\
2.1 & $5 \times 10^{-6}$ & $6 \times 10^{-6}$ & $9 \times 10^{-6}$ & $5 \times 10^{-6}$ \\
2.2 & $2 \times 10^{-6}$ & $1 \times 10^{-6}$ & $1 \times 10^{-6}$ & $1 \times 10^{-6}$ \\
\hline
\end{tabular}

a Estimated risks are summed over all pathways and radionuclides.

TABLE A.4 Radiological Risk Reduction Calculations for the Hypothetical Future Child ${ }^{\mathrm{a}}$

Carcinogenic Risk per Segment

\begin{tabular}{ccccc} 
Alternative & A & B & C & D \\
\hline Baseline & $5 \times 10^{-5}$ & $1 \times 10^{-4}$ & $9 \times 10^{-5}$ & $5 \times 10^{-5}$ \\
2.1 & $2 \times 10^{-5}$ & $3 \times 10^{-5}$ & $4 \times 10^{-5}$ & $2 \times 10^{-5}$ \\
2.2 & $7 \times 10^{-6}$ & $5 \times 10^{-6}$ & $6 \times 10^{-6}$ & $6 \times 10^{-6}$ \\
\hline
\end{tabular}

a Estimated risks are summed over all pathways and radionuclides. 


\section{A.4 REFERENCES FOR APPENDIX A}

Eckerman, K.F., and J.C. Ryman, 1993, External Exposure to Radionuclides in Air, Water, and Soil, Exposure-to-Dose Coefficients for General Application, Based on the 1987 Federal Protection Guidance, EPA 402-R-93-081, Federal Guidance Report No. 12, prepared by Oak Ridge National Laboratory, Oak Ridge, Tenn., for U.S. Environmental Protection Agency, Office of Radiation Programs, Washington, D.C.

U.S. Department of Energy, 1992, Baseline Assessment of the Chemical Plant Area of the Weldon Spring Site, DOE/ER/21548-091, prepared by Argonne National Laboratory, Environmental Assessment Division, Argonne, Ill., for U.S. Department of Energy, Oak Ridge Field Office, Oak Ridge, Tenn., Nov.

Yu, C., et al., 1993, Manual for Implementing Residual Radioactive Material Guidelines Using RESRAD, Version 5.0, ANL/EAD/LD-2, Argonne National Laboratory, Argonne, Ill., Sept. 
APPENDIX B:

CONTAMINANT UPTAKE MODELING FOR

TERRESTRIAL WILDLIFE 
APPENDIX B:

CONTAMINANT UPTAKE MODELING FOR TERRESTRIAL WILDLIFE

\section{B.1 INTRODUCTION}

Risks to terrestrial wildlife were estimated by modeling contaminant uptake via drinking water for three receptor species: the white-tailed deer, the white-footed mouse, and the great horned owl. The uptake modeling permitted prediction of an applied daily dose (ADD) for each receptor and each contaminant.

\section{B.2 MODEL METHODOLOGY}

Contaminant uptake from the ingestion of contaminated drinking water was estimated with the following equation:

$$
\mathrm{ADD}_{\mathrm{dw}}=\mathrm{C}_{\mathrm{dw}} \times \mathrm{FR} \times\left(\mathrm{IR}_{\mathrm{dw}} / \mathrm{BW}\right)
$$

where:

$$
\begin{aligned}
\mathrm{ADD}_{\mathrm{dw}}= & \text { applied daily dose from drinking water }(\mathrm{mg} / \mathrm{kg}-\mathrm{d}) ; \\
\mathrm{C}_{\mathrm{dw}}= & \begin{array}{l}
\text { exposure point concentration }(\mathrm{mg} / \mathrm{L}) \text { at the drinking water supply, } \\
\text { i.e., the Southeast Drainage; }
\end{array} \\
\mathrm{FR}= & \text { fraction of total water ingestion from contaminated source; } \\
\mathrm{IR}_{\mathrm{dw}}= & \text { ingestion rate of drinking water }(\mathrm{g} / \mathrm{d}) ; \text { and } \\
\mathrm{BW}= & \text { body weight }(\mathrm{g}) \text { of the receptor. }
\end{aligned}
$$

Contaminant uptake through food chain transfer was also considered for the great horned owl, and the uptake modeling included the water/white-footed mouse-great horned owl pathway.

\section{B.3 EXPOSURE FACTORS}

Values for drinking water and food ingestion rates, body weights, and home ranges were obtained from the Wildlife Exposure Factors Handbook (EPA 1993) and the open scientific literature. The exposure factors used for this risk assessment are presented in Tables B.1 through B.3. 
TABLE B.1 Exposure Factors for the White-Tailed Deer

\begin{tabular}{lcccc}
\hline \multicolumn{1}{c}{ Exposure Factor } & Mean & $\begin{array}{c}\text { Range or } \\
95 \% \text { UCL }\end{array}$ & $\begin{array}{c}\text { Geographic } \\
\text { Location }\end{array}$ & Source \\
\hline Body weight (g) & 90,000 & $-^{\mathrm{a}}$ & Missouri & Schwartz and Schwartz (1981) \\
Water ingestion rate (g/g-d) & 0.07 & - & - & Estimated $^{\mathrm{b}}$ \\
Home range (ha) & 160 & 260 & Missouri & Schwartz and Schwartz (1981) \\
Seasonality factor & 1.0 & - & - & \\
\hline
\end{tabular}

a A hyphen (-) indicates that the information was not applicable or not available.

b Estimated by the following allometric equations (EPA 1993):

Water Ingestion Rate $(\mathrm{L} / \mathrm{d})=0.099 \mathrm{~W}^{0.90}$, where W equals weight $(49.33 \mathrm{~kg})$; and

Normalized Water Ingestion Rate $(\mathrm{g} / \mathrm{g}-\mathrm{d})=($ Water Ingestion $[\mathrm{g} / \mathrm{d}]) \div \mathrm{W}(\mathrm{g})$.

TABLE B.2 Exposure Factors for the White-Footed Mouse

\begin{tabular}{lcccc}
\hline \multicolumn{1}{c}{ Exposure Factor } & Mean & $\begin{array}{c}\text { Range or } \\
\text { 95\% UCL }\end{array}$ & $\begin{array}{c}\text { Geographic } \\
\text { Location }\end{array}$ & Source \\
\hline Body weight (g) & 21 & $-{ }^{\mathrm{a}}$ & North America & Millar (1989) \\
Water ingestion rate (g/g-d) & 0.15 & - & - & Estimated $^{\mathrm{b}}$ \\
Home range (ha) & 0.06 & $0.054-0.072$ & Virginia & Wolff (1985) \\
\hline
\end{tabular}

a A hyphen (-) indicates that the information was not applicable or not available.

b Estimated by the following allometric equations (EPA 1993):

Water Ingestion Rate $(\mathrm{L} / \mathrm{d})=0.099 \mathrm{~W}^{0.90}$, where $\mathrm{W}$ equals weight $(0.021 \mathrm{~kg})$; and

Normalized Water Ingestion Rate $(g / g-d)=($ Water Ingestion $[g / d]) \div W(g)$. 
TABLE B.3 Exposure Factors for the Great Horned OwI

\begin{tabular}{|c|c|c|c|c|}
\hline Exposure Factor & Mean & $\begin{array}{l}\text { Range or } \\
95 \% \text { UCL } \\
\end{array}$ & $\begin{array}{c}\text { Geographic } \\
\text { Location }\end{array}$ & Source \\
\hline Body weight (g) & 1,505 &.$^{a}$ & Colorado & Craighead and Craighead (1969) \\
\hline Food ingestion rate (g/g-d) & 0.092 & - & Wyoming, Michigan & Craighead and Craighead (1969) \\
\hline Water ingestion rate $(\mathrm{g} / \mathrm{g}-\mathrm{d})$ & 0.052 & - & - & Estimated $^{b}$ \\
\hline Home range (ha) & 78.5 & - & - & Baumgartner (1939) \\
\hline Diet composition, mammals (\%) & 92 & - & Wyoming, Michigan & Craighead and Craighead (1969) \\
\hline \multicolumn{5}{|c|}{$\begin{array}{l}\text { a A hyphen (-) indicates that the information was not applicable or not available. } \\
\text { b Estimated by the following allometric equations (EPA 1993): } \\
\text { Water Ingestion Rate }(\mathrm{L} / \mathrm{d})=0.059 \mathrm{~W}^{0.67} \text {, where W equals weight }(1.219 \mathrm{~kg}) \text {; and } \\
\text { Normalized Water Ingestion Rate }(\mathrm{g} / \mathrm{g}-\mathrm{d})=(\text { Water Ingestion }[\mathrm{g} / \mathrm{d}]) \div \mathrm{W}(\mathrm{g}) \text {. }\end{array}$} \\
\hline \multicolumn{5}{|c|}{$\begin{array}{l}\text { Every effort was made to select exposure factors from populations nearest the Busch Conservation } \\
\text { Area. For the white-footed mouse and great horned owl, } 100 \% \text { of the ingested drinking water was } \\
\text { assumed to be obtained from the Southeast Drainage, whereas only } 7.4 \% \text { of the total water intake } \\
\text { for the white-tailed deer was considered to come from the drainage. For the deer, this diet fraction } \\
\text { was developed as the ratio of the total surface water area of the Southeast Drainage ( } 1.1 \text { ha) to the } \\
\text { total available surface water area ( } 15 \text { ha) within the home range of the deer, centered on the midpoint } \\
\text { of the drainage. Because of the much smaller home range sizes of the white-footed mouse and great } \\
\text { horned owl, these latter species were considered to obtain all their drinking water from the drainage. }\end{array}$} \\
\hline
\end{tabular}

\section{B.4 MODEL ASSUMPTIONS} assumptions:

Modeling contaminant uptake and determining the ADD includes the following

- Consistent with EPA (1993) guidance, the home range used in this assessment includes both daily activity and foraging ranges.

- All foraging activities of each receptor are constant and uniformly distributed over the receptor's entire home range.

- Contaminant uptake by biota will not significantly affect the environmental concentration of contaminants.

- Contaminant assimilation is assumed to be complete $(100 \%)$. 


\section{B.5 DOSE ESTIMATES}

Predicted daily dose estimates via the drinking water pathway are presented in Table B.4. Risks to wildlife were estimated by calculating a value of the ecological effects quotient (EEQ). This value is calculated as the ratio between the predicted daily dose and a no-observed-adverse-effects (NOAEL) benchmark dose concentration. Benchmark values used in this ecological assessment are presented in Table B.5. Estimated EEQ values are presented in Table 10. 
TABLE B.4 Estimated Applied Daily Dose for the White-Tailed Deer, White-Footed Mouse, and Great Horned Owl Using the Southeast Drainage

Applied Daily Dose (mg/kg-d)

\begin{tabular}{|c|c|c|c|}
\hline Contaminant $^{\mathrm{a}}$ & White-Tailed Deer ${ }^{\mathrm{a}}$ & White-Footed Mouse ${ }^{\mathrm{a}}$ & Great Horned Owl ${ }^{\mathrm{b}}$ \\
\hline \multicolumn{4}{|l|}{ Metals } \\
\hline Aluminum & 0.001 & 0.034 & 0.015 \\
\hline Antimony & $<0.001$ & 0.14 & 0.005 \\
\hline Barium & $<0.001$ & 0.019 & 0.008 \\
\hline Chromium & $<0.001$ & 0.004 & 0.002 \\
\hline Copper & $<0.001$ & $<0.001$ & $<0.001$ \\
\hline Iron & 0.001 & 0.044 & 0.020 \\
\hline Lead & $<0.001$ & 0.002 & 0.001 \\
\hline Magnesium & 0.084 & 2.6 & 1.2 \\
\hline Manganese & $<0.001$ & 0.012 & 0.006 \\
\hline Molybdenum & $<0.002$ & 0.006 & 0.003 \\
\hline Nickel & $<0.001$ & 0.001 & $<0.001$ \\
\hline Silver & $<0.001$ & $<0.001$ & $<0.001$ \\
\hline Uranium, total & 0.004 & 0.13 & 0.057 \\
\hline Vanadium & $<0.001$ & 0.004 & 0.002 \\
\hline Zinc & $<0.001$ & 0.006 & 0.003 \\
\hline \multicolumn{4}{|l|}{ Inorganic anion } \\
\hline Nitrate & 0.16 & 5.0 & 2.3 \\
\hline \multicolumn{4}{|l|}{ Nitroaromatic compounds } \\
\hline 1,3,5-Trinitrobenzene & $<0.001$ & $<0.001$ & $<0.001$ \\
\hline 1,3-Dinitrobenzene & $<0.001$ & $<0.001$ & $<0.001$ \\
\hline 2,4,6-Trinitrotoluene & 0.001 & 0.040 & 0.018 \\
\hline 2,4-Dinitrotoluene & $<0.001$ & 0.002 & $<0.001$ \\
\hline 2,6-Dinitrotoluene & $<0.001$ & 0.002 & $<0.001$ \\
\hline 2-Amino-4,6-dinitrotoluene & $<0.001$ & $<0.001$ & $<0.001$ \\
\hline 4-Amino-2,6-dinitrotoluene & $<0.001$ & $<0.001$ & $<0.001$ \\
\hline Nitrobenzene & $<0.001$ & $<0.001$ & $<0.001$ \\
\hline
\end{tabular}

a Drinking water pathway.

b Drinking water and food ingestion pathways. 
TABLE B.5 Benchmark Values for NOAEL Doses Used to Estimate Risks to Ecological Receptors

\begin{tabular}{|c|c|c|}
\hline Contaminant & Receptor & $\begin{array}{l}\text { Benchmark } \\
(\mathrm{mg} / \mathrm{kg}-\mathrm{d})^{\mathrm{a}}\end{array}$ \\
\hline \multicolumn{3}{|l|}{ Metals } \\
\hline \multirow[t]{3}{*}{ Aluminum } & White-footed mouse & 2.1 \\
\hline & White-tailed deer & 0.16 \\
\hline & Great horned owl & 66 \\
\hline \multirow[t]{3}{*}{ Antimony } & White-footed mouse & 0.14 \\
\hline & White-tailed deer & 0.010 \\
\hline & Great horned owl & $N A^{b}$ \\
\hline \multirow[t]{3}{*}{ Barium } & White-footed mouse & 14 \\
\hline & White-tailed deer & 1.0 \\
\hline & Great horned owl & 12 \\
\hline \multirow[t]{3}{*}{ Chromium } & White-footed mouse & 8.2 \\
\hline & White-tailed deer & 0.61 \\
\hline & Great horned owl & 1.2 \\
\hline \multirow[t]{3}{*}{ Copper } & White-footed mouse & 41 \\
\hline & White-tailed deer & 3.1 \\
\hline & Great horned owl & 43 \\
\hline \multirow[t]{3}{*}{ Lead } & White-footed mouse & 20 \\
\hline & White-tailed deer & 1.5 \\
\hline & Great horned owl & 2.2 \\
\hline \multirow[t]{3}{*}{ Manganese } & White-footed mouse & 220 \\
\hline & White-tailed deer & 16 \\
\hline & Great horned owl & 460 \\
\hline \multirow[t]{3}{*}{ Molybdenum } & White-footed mouse & 0.29 \\
\hline & White-tailed deer & 0.020 \\
\hline & Great horned owl & 4.5 \\
\hline \multirow[t]{3}{*}{ Nickel } & White-footed mouse & 100 \\
\hline & White-tailed deer & 7.5 \\
\hline & Great horned owl & 80 \\
\hline \multirow[t]{3}{*}{ Uranium, total } & White-footed mouse & 3.3 \\
\hline & White-tailed deer & 0.25 \\
\hline & Great horned owl & 19 \\
\hline
\end{tabular}


TABLE B.5 (Cont.)

\begin{tabular}{|c|c|c|}
\hline Contaminant & Receptor & $\begin{array}{l}\text { Benchmark } \\
(\mathrm{mg} / \mathrm{kg}-\mathrm{d})^{\mathrm{a}}\end{array}$ \\
\hline \multicolumn{3}{|l|}{ Metals (cont.) } \\
\hline \multirow[t]{3}{*}{ Vanadium } & White-footed mouse & 0.47 \\
\hline & White-tailed deer & 0.040 \\
\hline & Great horned owl & 13 \\
\hline \multirow[t]{3}{*}{ Zinc } & White-footed mouse & 400 \\
\hline & White-tailed deer & 30 \\
\hline & Great horned owl & 20 \\
\hline \multicolumn{3}{|l|}{ Inorganic anion } \\
\hline \multirow[t]{3}{*}{ Nitrate } & White-footed mouse & 1,700 \\
\hline & White-tailed deer & 130 \\
\hline & Great horned owl & NA \\
\hline \multicolumn{3}{|l|}{ Nitroaromatic compounds } \\
\hline \multirow[t]{3}{*}{ 1,3,5-Trinitrobenzene } & White-footed mouse & $6.7^{c}$ \\
\hline & White-tailed deer & $0.90^{\mathrm{c}}$ \\
\hline & Great horned owl & NA \\
\hline \multirow[t]{3}{*}{ 1,3-Dinitrobenzene } & White-footed mouse & $0.23^{c}$ \\
\hline & White-tailed deer & $0.030^{c}$ \\
\hline & Great horned owl & NA \\
\hline \multirow[t]{3}{*}{ 2,4,6-Trinitrotoluene } & White-footed mouse & $3.0^{\mathrm{c}}$ \\
\hline & White-tailed deer & $0.40^{\mathrm{c}}$ \\
\hline & Great horned owl & NA \\
\hline
\end{tabular}

a Benchmark values from Opresko et al. (1995), unless otherwise noted.

b $\mathrm{NA}=$ no benchmark available.

c Benchmark values from Talmage and Opresko (1996). 


\section{B.6 REFERENCES FOR APPENDIX B}

Baumgartner, F.M., 1939, "Territory and Population in the Great Horned Owl," Auk 56:274-282.

Craighead, J.J., and F.C. Craighead, 1969, Hawks, Owls, and Wildlife, Dover Publications, Inc., New York, N.Y.

Millar, J.S., 1989, "Reproduction and Development," pp. 169-205 in Advances in the Study of Peromyseus (Rodentia), G.L. Kirkland and J.N. Lane (editors), Texas Tech University Press, Lubbock, Texas.

Opresko, D.M., et al., 1995, Toxicological Benchmarks for Wildlife: 1995 Revision, ES/ER/ TM-86/R1, Oak Ridge National Laboratory, Oak Ridge, Tenn.

Schwartz, C.W., and E.R. Schwartz, 1981, The Wild Mammals of Missouri, University of Missouri Press and Missouri Department of Conservation, Columbia, Mo.

Talmage, S.S., and D.M. Opresko, 1996, Ecological Criteria/Screening Benchmarks for Screening Effects of Munitions Compounds on the Environment, prepared by Oak Ridge National Laboratory, Oak Ridge, Tenn., for U.S. Environmental Protection Agency, National Exposure Research Laboratory, Cincinnati, Ohio (draft).

Wolff, J.O., 1985, "The Effects of Density, Food, and Interspecific Interference on Home Range Size in Peromyscus leucopus and Peromyscus maniculatos," Canadian Journal of Zoology 63:2657-2662.

U.S. Environmental Protection Agency, 1993, Wildlife Exposure Factors Handbook, Vol. 1, EPA/600/ R-93/187a, Office of Research and Development, Washington, D.C., Dec. 
APPENDIX C:

\section{POTENTIAL REGULATORY REQUIREMENTS} FOR THE SOUTHEAST DRAINAGE 
70 
TABLE C.1 Potentially Applicable or Relevant and Appropriate Requirements (ARARs) and To-Be-Considered Requirements for the Southeast Drainage Area

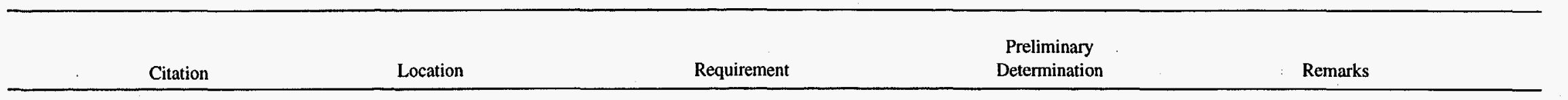

Location-Specific ARARs

Endangered Species Act, as amended (16 USC 1531-1543; 50 CFR 17.402)

Any

Fish and Wildlife Coordination Act (16 USC 661-666; 40 CFR 4.302(a))

Missouri Wildlife Code (1989) (RSMo. 252.240; 3 CSR 10-4.111).

Endangered Species

Missouri Wildlife Code (1989) (RSMo. 252.240; 3 CSR 10-4.110), General Prohibition; Application

Floodplain Management (Executive Order 11988; 10 CFR Part 1022)
Federal agencies should ensure that any action authorized, funded, or carried out by the agency is not likely to jeopardize the continued existence of any threatened or endangered species or destroy or adversely modify any critical habitat.

Adequate protection of fish and wildlife resources is required when any federal department or agency proposes or authorizes any modification (e.g., diversion or channeling) of any stream or other water body or any modification of areas affecting any stream or other water body.

Endangered species, i.e., those designated by the U.S. Department of Interior and the Missour

Department of Conservation as threatened or endangered (see 1978 Code, RSMo. 252.240), should not be pursued, taken, possessed, or killed.

Any

Wildlife, including their homes and eggs, should not be taken, molested, hunted, trapped, killed, or transported except under permitted conditions.

Federal agencies should avoid, to the maximum extent possible, any adverse impacts associated with direct and indirect development of a floodplain; DOE must evaluate all actions that might impact a floodplain
Potentially applicable

No critical habitat has been identified in the Southeast Drainage area, and no adverse impacts to threatened or endangered species are expected to result from the removal action. Informal consultations have occurred with the U.S. Fish and Wildlife Service; if such species might be affected, the requirement would be applicable.

Potentially applicable If areas in the stream exceeding 4 ha (10 acres) are to be modified through sediment remediation activities, these requirements would be applicable.

Potentially applicable

No adverse impacts to threatened or endangered species are expected to result from the removal action; however, if such species might be affected, the requirement would be applicable.

Potentially applicable

The removal action should not significantly molest, hunt, trap, kill, or transport wildlife or their homes or eggs; however, if such species were to be impacted, this requirement would be applicable.

Potentially applicable

This requirement would be applicable at the Southeast Drainage area, which lies in the Missouri River floodplain. Mitigative measures would be taken to minimize any adverse impacts, and the areas would be restored to original conditions upon completion of the removal action. A floodplain assessment has been prepared. 


\section{TABLE C.1 (Cont.)}

\begin{tabular}{|c|c|c|c|c|}
\hline Citation & Location & Requirement & $\begin{array}{l}\text { Preliminary } \\
\text { Determination }\end{array}$ & Remarks \\
\hline \multicolumn{5}{|l|}{ Location-Specific ARARs (Cont.) } \\
\hline Governor's Executive Order 82-19 & Floodplains & $\begin{array}{l}\text { Potential effects of actions taken in a floodplain should } \\
\text { be evaluated to avoid adverse impacts. }\end{array}$ & $\begin{array}{l}\text { Potentially } \\
\text { applicable }\end{array}$ & $\begin{array}{l}\text { This requirement would be applicable at the } \\
\text { Southeast Drainage area, which lies in the } \\
\text { Missouri River floodplain. Mitigative measures } \\
\text { would be taken to minimize any adverse impacts, } \\
\text { and the area would be restored to original } \\
\text { conditions upon completion of the removal } \\
\text { action. }\end{array}$ \\
\hline Citation & Contaminant & Requirement & $\begin{array}{c}\text { Preliminary } \\
\text { Determination }\end{array}$ & Remarks \\
\hline
\end{tabular}

\section{Contaminant-Specific ARAR}

Environmental Radiation Protection

Standards for Nuclear Power Operations

(40 CFR Part 190)

Radiation Protection of the Public and the Environment (DOE Order 5400.5);

Proposed Radiation Protection of the

Public and the Environment (10 CFR

Part 834; 58 FR 16268, March 25, 1993)
Radiation

The annual dose equivalent must not exceed 25 mrem to

the whole body 75 mr

any other organ of any member of the public as the

result of exposures to any planned discharges of

radioactive materials, except for radon and its decay

products.

Radiation

The basic dose limit for nonoccupationally exposed

individuals is $100 \mathrm{mrem} / \mathrm{yr}$ above background effective

dose equivalent. Also, all radiation exposures should be

reduced to levels as low as reasonably achievable. The

basic dose limit for exposure to residual radioactive

material is also $100 \mathrm{mrem} / \mathrm{yr}$ above background effective dose equivalent.
Potentially

relevant and

appropriate

To be

considered

are pertinent to DOE activities. Once $10 \mathrm{CFR}$

Part 834 is promulgated as a final rule, those

requirements would be applicable.
Toutheast Drainage area is not a nuclear power operation; however, they might be relevant and appropriate to the proposed action. 
TABLE C.1 (Cont.)

\begin{tabular}{cccc} 
& & & \\
Preliminary & \\
Ditation & Contaminant & Requirement & Determination \\
\hline
\end{tabular}

Contaminant-Specific ARARs (Cont.)

Radionuclides

in soil

Radionuclides

in sediment

Missouri Radiation Regulations:

Protection against Ionizing Radiation

(19 CSR 20-10.040), Maximum

Permissible Exposure Limits

National Emission Standards for Hazardous Air Pollutants (40 CFR Part 61), Subpart H, National Emission Standards for Emissions of

Radionuclides other than Radon from

Department of Energy Facilities

Radiation

Radionuclides other than radon-220 and

radon-222

in air
Residual concentrations in soil of radionuclides, other than radium, shall be derived from this basic dose limit by means of an environmental pathway analysis using a procedure where it is averaged over an area of $100 \mathrm{~m}^{2}$. For radium, the generic guidelines for residual concentrations are $5 \mathrm{pCi} / \mathrm{g}$, averaged over the first $15 \mathrm{~cm}$ of soil below the surface and $15 \mathrm{pCi} / \mathrm{g}$ averaged over $15-\mathrm{cm}$-thick layers of soil more than $15 \mathrm{~cm}$ below the surface. These concentrations are for total radium, i.e., the sum of radium-226 and radium-228.

To be

considered tormwater runoff) may be released to natural

waterways if the concentration of radioactive material in settleable solids does not exceed $5 \mathrm{pCi} / \mathrm{g}$ above

background levels for alpha-emitting radionuclides or 50

$\mathrm{pCi} / \mathrm{g}$ above background level for beta-gamma-emitting radionuclides.

For persons outside a controlled area, the maximum permissible whole-body dose due to sources in or

migrating from the controlled area is limited to $2 \mathrm{mrem}$ in any 1 hour, 0.1 rem in any 7 consecutive days, and

0.5 rem in any 1 year. (Note: Controlled area is an area that requires control of access, occupancy, and working conditions for radiation protection purposes; $0.5 \mathrm{rem}=$ 500 mrem.)

Emission of radionuclides other than radon-220 and radon-222 to the ambient air from DOE facilities should not result in an effective dose equivalent of $>10 \mathrm{mrem} / \mathrm{yr}$ to any member of the public.
To be considered

Potentially applicable

Potentially relevant and appropriate
Although these requirements could be considered pertinent to the proposed action, the contamination conditions in the Southeast Drainage are much different than those for which these requirements were developed. The highly localized nature of contamination would make averaging over an area of $100 \mathrm{~m}^{2}$ impractical, and the residual concentrations of radium were meant to apply to future land-use conditions significantly different from those in the drainage. Site-specific cleanup guidelines were developed to ensure protectiveness for potential future exposure to radioactive contaminants in the drainage. These guidelines are given in Chapter 6 of this document.

Although no action is anticipated that would release a liquid process waste stream, the limits for preventing buildup of radionuclide concentrations in sediment might be pertinent to developing a concentration level for sediment remediation.

These requirements would be applicable to protection of the public during implementation of the action.

These requirements would be relevant and appropriate to protection of the public during implementation of the removal action at the Southeast Drainage area, although they would not be applicable because the Southeast Drainage area is not a DOE facility. 
TABLE C.1 (Cont.)

\begin{tabular}{|c|c|c|c|c|}
\hline Citation & Contaminant & Requirement & $\begin{array}{l}\text { Preliminary } \\
\text { Determination }\end{array}$ & Remarks \\
\hline \multicolumn{5}{|l|}{ Contaminant-Specific ARARs (Cont.) } \\
\hline $\begin{array}{l}\text { National Emission Standards for } \\
\text { Hazardous Air Pollutants ( } 40 \text { CFR } \\
\text { Part 61), Subpart Q, National Emission } \\
\text { Standards for Radon Emissions from } \\
\text { Department of Energy Facilities }\end{array}$ & $\begin{array}{l}\text { Radon-222 } \\
\text { in air }\end{array}$ & $\begin{array}{l}\text { Emission of radon- } 222 \text { to the ambient air from DOE } \\
\text { facilities should not exceed } 20 \mathrm{pCi} / \mathrm{m}^{3} \text { as an average for } \\
\text { the entire source. }\end{array}$ & $\begin{array}{l}\text { Potentially } \\
\text { relevant and } \\
\text { appropriate }\end{array}$ & $\begin{array}{l}\text { These requirements would be relevant and } \\
\text { appropriate to protection of the public during } \\
\text { implementation of the removal action at the } \\
\text { Southeast Drainage area, although they would not } \\
\text { be applicable because the Southeast Drainage } \\
\text { area is not a DOE facility. }\end{array}$ \\
\hline $\begin{array}{l}\text { National Emission Standards for } \\
\text { Hazardous Air Pollutants ( } 40 \text { CFR } \\
\text { Part 61), Subpart T, National Emission } \\
\text { Standards for Radon Emissions from the } \\
\text { Disposal of Uranium Mill Tailings }\end{array}$ & $\begin{array}{l}\text { Radon-222 } \\
\text { in air }\end{array}$ & $\begin{array}{l}\text { Emission of radon- } 222 \text { to the ambient air from uranium } \\
\text { mill tailing piles should not exceed } 20 \mathrm{pCi} / \mathrm{m}^{3} \text {. }\end{array}$ & $\begin{array}{l}\text { Potentially } \\
\text { relevant and } \\
\text { appropriate }\end{array}$ & $\begin{array}{l}\text { These requirements would be relevant and } \\
\text { appropriate to protection of the public during } \\
\text { implementation of the removal action at the } \\
\text { Southeast Drainage area, although they would not } \\
\text { be applicable because the Southeast Drainage } \\
\text { area is not a uranium mill tailings storage site. }\end{array}$ \\
\hline $\begin{array}{l}\text { Health and Environmental Protection } \\
\text { Standards for Uranium and Thorium Mill } \\
\text { Tailings ( } 40 \text { CFR Part 192), Subpart A, } \\
\text { Standards for the Control of Residual } \\
\text { Radioactive Material from Inactive } \\
\text { Uranium Processing Sites }\end{array}$ & $\begin{array}{l}\text { Radon-222 } \\
\text { in air }\end{array}$ & $\begin{array}{l}\text { The annual average release rate of radon- } 222 \text { to the } \\
\text { atmosphere applied over the entire surface of a disposal } \\
\text { site should not exceed } 20 \mathrm{pCi} / \mathrm{m}^{2}-\mathrm{s} \text {, and the annual } \\
\text { average concentration of radon- } 222 \text { in air at or above } \\
\text { any location outside the disposal site should not be } \\
\text { increased by more than } 0.5 \mathrm{pCi} / \mathrm{L} \text {. Releases of } \\
\text { radon- } 222 \text { from residual radioactive material to the }\end{array}$ & $\begin{array}{l}\text { Potentially } \\
\text { relevant and } \\
\text { appropriate }\end{array}$ & $\begin{array}{l}\text { The Southeast Drainage is not a designated } \\
\text { uranium processing site, so these requirements } \\
\text { would not be applicable; however, they could be } \\
\text { considered relevant and appropriate because the } \\
\text { site contains material sufficiently similar to } \\
\text { uranium mill tailings and the potential release } \\
\text { issue could be pertinent to final site conditions. }\end{array}$ \\
\hline
\end{tabular}

atmosphere should not exceed an average release rate of

$20 \mathrm{pCi} / \mathrm{L} \mathrm{per} \mathrm{m}^{3} / \mathrm{s}$ or increase the average annual

concentration of radon-222 in air by more than

$0.5 \mathrm{pCi} / \mathrm{L}$ 


\section{TABLE C.1 (Cont.)}

\section{Citation}

\section{Contaminant-Specific ARARs (Cont.)}

Radiation Protection of the Public and the Environment (DOE Order 5400.5);

Proposed Radiation Protection of the

Public and Environment (10 CFR

Part 834; 58 FR 16268, March 25, 1993)

\section{Contaminant}

Requirement

Radon-222

in air

air

Releases of radon-222 from residual radioactive material disposal sites should not exceed an annual average

release rate of $20 \mathrm{pCi} / \mathrm{m}^{2}-\mathrm{s}$, cause outdoor annual

concentrations of radon-220 or radon-222 resulting from facilities where sources of radon are handled to exceed

$3 \mathrm{pCi} / \mathrm{L}$ above background at the facility or beyond the

facility border that is accessible to the public, or increase

the annual average radon- 222 concentration at or above

any location outside the boundary of the contaminated

area by more than $0.5 \mathrm{pCi} / \mathrm{L}$.

The above-background concentration of radon-222 in air above an interim storage facility should not exceed

$100 \mathrm{pCi} / \mathrm{L}$ at any point, an annual average of $30 \mathrm{pCi} / \mathrm{L}$

over the site, or an annual average of $3 \mathrm{pCi} / \mathrm{L}$ at or above any location outside the site. The derived concentration guide for immersion in air in an uncontrolled area for both radon-220 and radon-222 is $3 \mathrm{pCi} / \mathrm{L}$. (See also the discussion for DOE Order 5820.2A.)
Preliminary

Determination

Remarks
To be

considered
Although not promulgated standards, these requirements might be pertinent to releases of radon-222 during remedial activities. Once 10 CFR Part 834 is promulgated as a final rule, these requirements would be applicable. 


\section{TABLE C.1 (Cont.)}

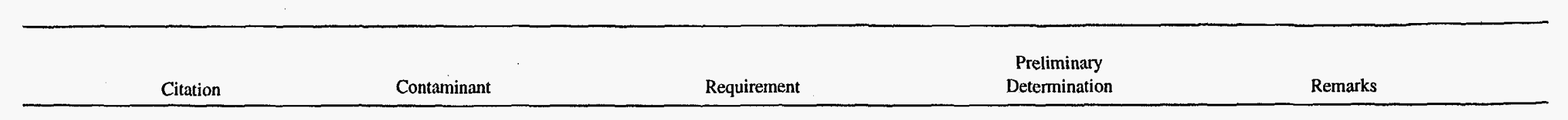

Contaminant-Specific ARARs (Cont.)

Radiation Protection of the Public and the Environment (DOE Order 5400.5)

Proposed Radiation Protection of the Public and the Environment (10 CFR Part 834; 58 FR 16268, March 25, 1993)

\section{Radionuclides}

in air

Radionuclides Radion
Residual concentrations of radionuclides in air in uncontrolled areas are limited to derived concentration guides $(\mu \mathrm{Ci} / \mathrm{mL})$ as follows:

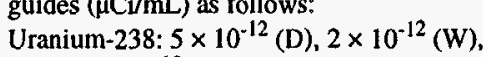
and $1 \times 10^{-13}(\mathrm{Y})$;

Radium-226: $1 \times 10^{-12}(\mathrm{~W})$

Radium-228: $3 \times 10^{-12}(\mathrm{~W})$;

Radon-220: $3 \times 10^{-9}(\mathrm{D}), 3 \times 10^{-9}(\mathrm{~W})$, and

$3 \times 10^{-9}(\mathrm{Y})$;

Radon-222: $3 \times 10^{-9}(\mathrm{D}), 3 \times 10^{-9}(\mathrm{~W})$, and

$$
3 \times 10^{-9}(\mathrm{Y})
$$$$
\text { Thorium-230: } 43 \times 10^{-14}(\mathrm{~W}), 5 \times 10^{-14}(\mathrm{Y}) \text {. }
$$

$\mathrm{D}, \mathrm{W}$, and $\mathrm{Y}$ represent lung retention classes; removal half-times assigned to the compounds in classes $D, W$, and $\mathrm{Y}$ are $0.5,50$, and 500 days, respectively. Exposure conditions assume an inhalation rate of $8,400 \mathrm{~m}^{3}$ of air per year (based on an exposure over 24 hours per day, 365 days per year).

Note: Derived concentration guides for radon are being assessed by DOE. Until that review is completed, the value of $3 \times 10^{-9}$ shall be used for DOE facilities.

DOE activities shall be conducted in a manner such that a release of radioactive material to the atmosphere shall not cause any member of the public to receive a total effective dose equivalent in excess of $10 \mathrm{mrem} / \mathrm{yr}$.
These requirements would be applicable for protection of the public during implementation of the removal action.
To be considered
To be

considered

Although these DOE requirements are not yet promulgated, they should be considered. Once finalized, 10 CFR Part 834 would be applicable. 
TABLE C.1 (Cont.)

\begin{tabular}{cccc}
\hline & & Preliminary \\
Citation & Contaminant & Requirement & Determination \\
\hline
\end{tabular}

Contaminant-Specific ARARs (Cont.)

Missouri Radiation Regulations;

Protection against Ionizing Radiation

(19 CSR 20-10.040), Maximum

Permissible Exposure Limits

Missouri Water Quality Standards (10 CSR 20-7.031)

Contaminants

in water

Radionuclides

in air

The concentrations above natural background of radionuclides in air outside a controlled area, averaged over any calendar quarter, should not exceed the following:

\begin{tabular}{lcc}
\hline & \multicolumn{2}{c}{$\begin{array}{c}\text { Concentration Limit } \\
(\mu \mathrm{Ci} / \mathrm{mL})\end{array}$} \\
\cline { 2 - 3 } Isotope & Soluble & Insoluble \\
\hline Radium-226 & $1 \times 10^{-12}$ & $6 \times 10^{-9}$ \\
Radium-228 & $2 \times 10^{-12}$ & $1 \times 10^{-12}$ \\
Radon-222 & $1 \times 10^{-9}$ & $\mathrm{NA}^{\mathrm{a}}$ \\
Thorium-230 & $8 \times 10^{-14}$ & $3 \times 10^{-13}$ \\
Uranium-238 & $3 \times 10^{-12}$ & $5 \times 10^{-12}$ \\
\hline
\end{tabular}

a Not applicable because radon-222 is a gas.

All streams and lakes shall conform with state and

federal limits for radionuclides established for drinking

water supply (i.e., maximum contaminant levels).
Potentially

applicable

These requirements would be applicable to

protection of the public during implementation of the removal action.

Potentially applicable
These regulations apply to the contaminant levels in surface water and would be applicable to this removal action. 


\section{TABLE C.1 (Cont.)}

\begin{tabular}{|c|c|c|c|c|c|}
\hline Citation & Contaminant & & ment & $\begin{array}{l}\text { Preliminary } \\
\text { Determination }\end{array}$ & Remarks \\
\hline \multicolumn{6}{|l|}{ Contaminant-Specific ARARs (Cont.) } \\
\hline \multirow[t]{3}{*}{$\begin{array}{l}\text { Safe Drinking Water Act (42 USC } \\
\text { 300G); National Primary Drinking Water } \\
\text { Regulations ( } 40 \text { CFR Part 141), } \\
\text { Subpart B, Maximum Contaminant } \\
\text { Levels; Subpart G, National Revised } \\
\text { Primary Drinking Water Regulations, } \\
\text { Maximum Contaminant Levels; Missouri } \\
\text { Drinking Water Regulations, Maximum } \\
\text { Contaminant Levels (10 CSR 60-4.060) }\end{array}$} & \multirow[t]{3}{*}{$\begin{array}{l}\text { Contarminants } \\
\text { in water }\end{array}$} & \multicolumn{2}{|c|}{$\begin{array}{l}\text { Maximum contaminant levels for drinking water } \\
\text { delivered directly to the ultimate user of a public water } \\
\text { system are as follows: } \\
\text { Combined radium- } 226 \text { and radium-228, } 5 \mathrm{pCi} / \mathrm{L} \\
\text { Gross alpha particle activity (including radium- } 226 \text { but } \\
\text { excluding radon and uranium), } 15 \mathrm{pCi} / \mathrm{L} \\
\text { Beta particle and photon radioactivity, } 4 \mathrm{mrem} / \mathrm{yr} \\
\text { (annual dose equivalent; if gross beta activity } \\
\text { exceeds } 50 \mathrm{pCi} / \mathrm{L} \text {, isotopic analysis and organ- } \\
\text { specific dose calculations should be made to } \\
\text { ensure that this total dose limit is met). } \\
\text { Maximum contaminant levels for other contami- } \\
\text { nants are as follows: }\end{array}$} & $\begin{array}{l}\text { Potentially } \\
\text { relevant and } \\
\text { appropriate }\end{array}$ & $\begin{array}{l}\text { These requirements would not be applicable } \\
\text { because the water impacted by the site would not } \\
\text { be used directly as a drinking water supply; } \\
\text { however, they might be relevant and appropriate } \\
\text { to determine levels of contaminants of concern in } \\
\text { surface water in the drainage. }\end{array}$ \\
\hline & & $\begin{array}{l}\text { Antimony } \\
\text { Barium } \\
\text { Chromium } \\
\text { Copper } \\
\text { Lead } \\
\text { Nickel } \\
\text { Thallium }\end{array}$ & $\begin{array}{l}0.006 \mathrm{mg} / \mathrm{L} \\
2 \mathrm{mg} / \mathrm{L} \\
0.1 \mathrm{mg} / \mathrm{L} \\
1.3 \mathrm{mg} / \mathrm{L}^{\mathrm{a}} \\
0.015 \mathrm{mg} / \mathrm{L}^{\mathrm{a}} \\
0.1 \mathrm{mg} / \mathrm{L}^{\mathrm{b}} \\
0.0005 \mathrm{mg} / \mathrm{L}\end{array}$ & & \\
\hline & & $\begin{array}{ll}\text { a } & \text { Action } \\
\text { b } & \text { Being }\end{array}$ & & & \\
\hline $\begin{array}{l}\text { Health and Environmental Protection } \\
\text { Standards for Uranium and Thorium Mill } \\
\text { Tailings ( } 40 \text { CFR Part 192), Subpart B, } \\
\text { Standards for Cleanup of Land and } \\
\text { Buildings Contaminated with Residual } \\
\text { Radioactive Materials from Inactive } \\
\text { Uranium Processing Sites }\end{array}$ & $\begin{array}{l}\text { Radium } \\
\text { in soil }\end{array}$ & $\begin{array}{l}\text { Residual concentrat } \\
\text { designated uranium } \\
\text { background by mor } \\
\text { soil or } 15 \mathrm{pCi} / \mathrm{g} \text { in } \mathrm{e} \\
\text { averaged over an ar } \\
\text { indicated for radium } \\
\text { thorium by-product }\end{array}$ & $\begin{array}{l}\text { lium- } 226 \text { in soil at a } \\
\mathrm{g} \text { site should not exceed } \\
\mathrm{Ci} / \mathrm{g} \text { in the top } 15 \mathrm{~cm} \text { of } \\
\text { layer below the top layer, } \\
\mathrm{m}^{2} \text {. (Similar limits are } \\
\text { ubpart } \mathrm{E} \text {, which addresses }\end{array}$ & $\begin{array}{l}\text { Potentially } \\
\text { relevant and } \\
\text { appropriate }\end{array}$ & $\begin{array}{l}\text { The Southeast Drainage is not a designated } \\
\text { uranium processing site, so these requirements } \\
\text { would not be applicable; however, they could be } \\
\text { considered relevant and appropriate because the } \\
\text { site contains material sufficiently similar to } \\
\text { uranium mill tailings and the issue of residual } \\
\text { radionuclide concentrations in soil could be } \\
\text { pertinent to final site conditions. However, future } \\
\text { land-use conditions for which these concentration } \\
\text { limits were meant to apply are significantly } \\
\text { different from those in the drainage. Therefore, } \\
\text { these regulations might not be relevant and } \\
\text { appropriate. }\end{array}$ \\
\hline
\end{tabular}


TABLE C.1 (Cont.)

\begin{tabular}{|c|c|c|c|c|c|c|c|}
\hline Citation & Contaminant & \multicolumn{6}{|c|}{ Requirement } \\
\hline \multicolumn{8}{|l|}{ Contaminant-Specific ARARs (Cont.) } \\
\hline $\begin{array}{l}\text { Toxic Substance Control Act, as } \\
\text { amended (15 USC 2607-2629); } \\
\text { Polychlorinated Biphenyls Manu- } \\
\text { facturing, Processing, Distribution in } \\
\text { Commerce, and Use Prohibitions } \\
\text { (40 CFR 761.125) }\end{array}$ & PCBs in soil & \multicolumn{6}{|c|}{$\begin{array}{l}\text { For spills of materials contaminated with }>50 \mathrm{ppm} \text { PCBs } \\
\text { in unrestricted-access areas (e.g., residential areas), soil } \\
\text { within the spill area must be excavated and backfilled } \\
\text { with soil containing }<1 \mathrm{ppm} \text { PCBs. Contaminated soil } \\
\text { may be decontaminated to } 10 \mathrm{ppm} \text { by weight by } \\
\text { excavating a minimum of } 25 \mathrm{~cm}(10 \text { in.) and backfilling } \\
\text { with soil containing }<1 \mathrm{ppm} \text { PCBs. }\end{array}$} \\
\hline \multirow{8}{*}{$\begin{array}{l}\text { Drinking Water Regulations and Health } \\
\text { Advisories, EPA 822-R-93-001, Office } \\
\text { of Water, May 1995; Proposed National } \\
\text { Primary Drinking Water Rule for } \\
\text { Radionuclides (40 CFR Part 141, } 56 \text { FR } \\
\text { 33050, July 18, 1991) }\end{array}$} & \multirow[t]{8}{*}{$\begin{array}{l}\text { Contaminants } \\
\text { in water }\end{array}$} & \multicolumn{6}{|c|}{$\begin{array}{l}\text { Health Advisories - Reference dose (RfD) and } \\
\text { Drinking Water Equivalent Level (DWEL) - have been } \\
\text { set as follows: }\end{array}$} \\
\hline & & & \multicolumn{5}{|c|}{ Health Advisories for $70-\mathrm{kg}$ Adult } \\
\hline & & & $\begin{array}{l}\text { Longer- } \\
\text { Term } \\
(\mathrm{mg} / \mathrm{L})\end{array}$ & $\underset{(\mathrm{mg} / \mathrm{kg}-\mathrm{d})}{\mathrm{RfD}}$ & $\begin{array}{l}\text { DWEL } \\
(\mathrm{mg} / \mathrm{L})\end{array}$ & $\begin{array}{l}\text { Lifetime } \\
(\mathrm{mg} / \mathrm{L})\end{array}$ & $\begin{array}{l}\text { Cancer } \\
\text { Risk } \\
(\mathrm{mg} / \mathrm{L}) \\
\left.\text { at } 10^{-4}\right)\end{array}$ \\
\hline & & $\begin{array}{l}\text { TNT } \\
\text { Manganese }\end{array}$ & $\stackrel{0.02}{-}$ & $\begin{array}{l}0.0005 \\
0.14^{\mathrm{a}} \\
0.005^{\mathrm{b}}\end{array}$ & 0.02 & 0.002 & 0.1 \\
\hline & & Zinc & 10 & 0.3 & 10 & 2 & -- \\
\hline & & 2,4-DNT & -- & -- & -- & -- & 0.005 \\
\hline & & 2,6-DNT & -. & $\ddot{-}$ & -- & -. & 0.005 \\
\hline & & Uranium & -. & 0.003 & -- & -- & -. \\
\hline
\end{tabular}

Preliminary

Determination

Remarks

in unrestricted-access areas (e.g., residential areas), so

will area must be excavated and backfilled

way be decontaminated to $10 \mathrm{ppm}$ by weight by

excavating a minimum of $25 \mathrm{~cm}$ (10 in.) and backfilling

with soil containing $<1$ ppm PCBs.

In water.

The 1991 Proposed National Primary Drinking Water Rule for Radionuclides proposed an MCL of $20 \mu \mathrm{g} / \mathrm{L}$ for uranium.
To be

considered

Any PCB contamination at the site would have preceded the effective date of this requirement hence, it is not applicable. Because EPA policy on PCB spill cleanup is not an enforceable requirement, it is not considered relevant and appropriate. However, these regulations are the guidelines used by the EPA for setting preliminary remediation goals for PCBs in soil at a remediation site.

To be

considered

These values are not regulations but are used in the absence of regulatory limits and, therefore, may be considered in setting surface water remediation levels. 
TABLE C.1 (Cont.)

\begin{tabular}{|c|c|c|c|c|}
\hline Citation & Contaminant & Requirement & $\begin{array}{c}\text { Preliminary } \\
\text { Determination }\end{array}$ & Remarks \\
\hline \multicolumn{5}{|l|}{ Contaminant-Specific ARARs (Cont.) } \\
\hline $\begin{array}{l}\text { Proposed Contaminated Sediment } \\
\text { Management Strategy (EPA 823-R-94- } \\
\text { 001; 59 FR 44,800, Aug. 30, 1994) }\end{array}$ & $\begin{array}{l}\text { Contaminants } \\
\text { in sediment }\end{array}$ & $\begin{array}{l}\text { This proposed strategy addresses assessment, } \\
\text { prevention, remediation, dredged material management, } \\
\text { research, and outreach concerning contaminated } \\
\text { sediments. The strategy will be used for CERCLA } \\
\text { remediations, including developing chemical-specific } \\
\text { sediment criteria and siting long-term disposal sites for } \\
\text { contaminated sediments. }\end{array}$ & $\begin{array}{l}\text { To be } \\
\text { considered }\end{array}$ & $\begin{array}{l}\text { This proposed strategy will not be a regulation } \\
\text { and, therefore, cannot be an ARAR. However, it } \\
\text { might be pertinent to the proposed action. }\end{array}$ \\
\hline
\end{tabular}

\begin{tabular}{l} 
Citation \\
\hline Action-Specific ARARs \\
Clean Air Act, as amended (42 USC \\
$7401-7642) ;$ National Primary and \\
Secondary Ambient Air Quality \\
Standards (40 CFR Part 50) - \\
Air Programs
\end{tabular}

Missouri Air Quality Standards; Air Quality Standards, Definitions, Sampling and Reference Methods, and Air Pollution Control Regulations for the State of Missouri (10 CSR 10-6.010), Ambient Air Quality

\section{Missouri Air Pollution Control} Regulations; Air Quality Standards and Air Pollution Control Regulations for the St. Louis Metropolitan Area (10 CSR 10-5.090), Restriction of Emissions of Visible Air Contaminants

Preliminary Determination

Remarks

Requirement

Concentrations of particulate matter $<10 \mu \mathrm{m}$ in diameter (PM-10) must not exceed $50 \mu \mathrm{g} / \mathrm{m}^{3}$ annual arithmetic mean and $150 \mu \mathrm{g} / \mathrm{m}^{3}$ 24-hour average concentration.

Concentrations are limited as identified for the National Primary and Secondary Ambient Air Quality Standards.

Emissions of particulate matter from any single source, not including uncombined water, should not be darker than the shades of density designated as No. 2 on the Ringelmann Chart or $20 \%$ opacity.
Potentially

relevant and appropriate

Potentially

relevant and appropriate

Potentially applicable
These requirements would not be applicable because they do not apply directly to sourcespecific emissions but to ambient concentrations. However, they would be addressed in controlling emissions of those contaminants that could result from the excavation activities.

These requirements would not be applicable because they do not apply directly to sourcespecific emissions but to ambient concentrations. However, they would be addressed in controlling emissions that could result from excavation activities.

These requirements would apply to emissions of particulate matter from removal activities. 
TABLE C.1 (Cont.)

\begin{tabular}{|c|c|c|c|c|}
\hline Citation & Medium & Requirement & $\begin{array}{c}\text { Preliminary } \\
\text { Determination }\end{array}$ & Remarks \\
\hline \multicolumn{5}{|l|}{ Action-Specific ARARs (Cont.) } \\
\hline $\begin{array}{l}\text { Missouri Air Quality Standards ( } 10 \text { CSR } \\
10-6.170) \text {, Restriction of Particulate } \\
\text { Matter to the Ambient Air beyond the } \\
\text { Premises of Origin }\end{array}$ & Air & $\begin{array}{l}\text { No person should permit the handling, transport, or } \\
\text { storage of any material without applying reasonable } \\
\text { measures as may be required to prevent fugitive } \\
\text { particulate matter to go beyond the premises of origin in } \\
\text { quantities that (1) the particulate matter remains visible } \\
\text { in the ambient air beyond the property line of origin or } \\
\text { (2) the particulate matter may be found on surfaces } \\
\text { beyond the property line of origin. To prevent particulate } \\
\text { matter from going beyond the premises of origin during } \\
\text { construction, repair, cleaning, or demolition of a } \\
\text { building or its appurtenances; construction or use of a } \\
\text { road, driveway, or open area; or operation of a com- } \\
\text { mercial or industrial installation, the following measures } \\
\text { may be required: revision of procedures involving } \\
\text { construction; repair, cleaning, and demolition of } \\
\text { buildings that produce particulate matter emissions; } \\
\text { revision of procedures involving paving or frequent } \\
\text { cleaning of roads; application of dust-free surfaces or } \\
\text { water; and planting and maintenance of a vegetative } \\
\text { ground cover. }\end{array}$ & $\begin{array}{l}\text { Potentially } \\
\text { applicable }\end{array}$ & $\begin{array}{l}\text { These requirements would be applicable to } \\
\text { releases of particulates from the removal } \\
\text { activities. }\end{array}$ \\
\hline $\begin{array}{l}\text { Missouri Water Pollution Control } \\
\text { Regulations, Storm Water Regulations } \\
\text { (10 CSR 20-6.200) }\end{array}$ & Storm water & $\begin{array}{l}\text { During construction or land disturbance activities, } \\
\text { measures must be taken to minimize the runoff of storm } \\
\text { water into waters of the state. }\end{array}$ & $\begin{array}{l}\text { Potentially } \\
\text { applicable }\end{array}$ & $\begin{array}{l}\text { These regulations would be applicable to any land } \\
\text { disturbance activities exceeding } 2 \text { ha ( } 5 \text { acres) of } \\
\text { total land area involved in the proposed action. } \\
\text { This application would also include identification } \\
\text { of local erosion and sediment control } \\
\text { requirements, such as those of the St. Charles } \\
\text { Soil and Water Conservation District, Model } \\
\text { Sediment and Erosion Control Regulations. } \\
\text { Under this local requirement, a plan or plans } \\
\text { addressing sediment and erosion control would } \\
\text { have to be submitted to and approved by the } \\
\text { County Highway Engineer. }\end{array}$ \\
\hline
\end{tabular}


TABLE C.1 (Cont.)

\begin{tabular}{|c|c|c|c|c|}
\hline Citation & Medium & Requirement & $\begin{array}{l}\text { Preliminary } \\
\text { Determination }\end{array}$ & Remarks \\
\hline \multicolumn{5}{|l|}{ Action-Specific ARARs (Cont.) } \\
\hline $\begin{array}{l}\text { Radioactive Waste Management (DOE } \\
\text { Order 5820.2A) }\end{array}$ & Waste & $\begin{array}{l}\text { DOE waste containing by-product material as defined in } \\
\text { Section } 1 \text { le(2) of the Atomic Energy Act, as amended, } \\
\text { or similarly contaminated residues derived from DOE } \\
\text { remedial actions, shall be managed consistent with the } \\
\text { requirements of the residual radioactive material } \\
\text { guidelines contained in } 40 \text { CFR Part } 192 \text {. }\end{array}$ & $\begin{array}{l}\text { To be } \\
\text { considered }\end{array}$ & $\begin{array}{l}\text { These are not promulgated standards and cannot } \\
\text { be ARARs; however, they might be pertinent to } \\
\text { the management of radioactive wastes resulting } \\
\text { from the removal action. }\end{array}$ \\
\hline $\begin{array}{l}\text { Proposed Radiation Protection of the } \\
\text { Public and the Environment (10 CFR } \\
\text { Part 834; 58 FR 16268, March 25, 1993) }\end{array}$ & $\begin{array}{l}\text { Radioactive } \\
\text { waste }\end{array}$ & $\begin{array}{l}\text { DOE activities should be conducted such that exposure } \\
\text { of members of the public from radioactive waste does } \\
\text { not exceed } 25 \mathrm{mrem} / \mathrm{yr} \text { effective dose equivalent from } \\
\text { all exposure pathways. }\end{array}$ & $\begin{array}{l}\text { To be } \\
\text { considered }\end{array}$ & $\begin{array}{l}\text { Once promulgated, these regulations would be } \\
\text { applicable to the removal action. }\end{array}$ \\
\hline $\begin{array}{l}\text { Missouri Radiation Regulations; } \\
\text { Protection against Ionizing Radiation } \\
\text { (19 CSR 20-10.070), Storage of } \\
\text { Radioactive Materials }\end{array}$ & $\begin{array}{l}\text { Radioactive } \\
\text { waste }\end{array}$ & $\begin{array}{l}\text { Radioactive materials should be stored in a manner that } \\
\text { will not result in the exposure of any person, during } \\
\text { routine access to a controlled area, in excess of the limits } \\
\text { identified in } 19 \text { CSR } 20-10.040 \text { (see related discussion } \\
\text { for contaminant-specific requirements); a facility used to } \\
\text { store materials that may emit radioactive gases or } \\
\text { airborne particulate matter should be vented to ensure } \\
\text { that the concentration of such substances in air does not } \\
\text { constitute a radiation hazard; and provisions should be } \\
\text { made to minimize the hazard to emergency workers in } \\
\text { the event of a fire, earthquake, flood, or windstorm. }\end{array}$ & $\begin{array}{l}\text { Potentially } \\
\text { applicable }\end{array}$ & $\begin{array}{l}\text { Pending the availability of a disposal facility, } \\
\text { these requirements would be applicable to the } \\
\text { temporary storage of certain material that would } \\
\text { be generated during the removal action. }\end{array}$ \\
\hline
\end{tabular}




\section{TABLE C.1 (Cont.)}

\begin{tabular}{cccc}
\hline & & & \\
Preliminary \\
Citation & Medium & Requirement & Determination \\
\hline
\end{tabular}

Action-Specific ARARs (Cont.)

Missouri Radiation Regulations;

Protection against Ionizing Radiation

(19 CSR 20-10.080), Control of

Radioactive Contamination

Toxic Substance Control Act, as amended (15 USC 2607-2629);

Polychlorinated Biphenyls

Manufacturing, Processing, Distribution

in Commerce, and Use Prohibitions

(40 CFR 761.60 and 761.65)

Toxic Substances Control Act, as amended (15 USC 2607-2629;

PL 94-499, et seque.); Polychlorinated

Biphenyls (PCBs) Manufacturing,

Processing, Distribution in Commerce,

and Use Prohibitions (40 CFR Part 761),

Subpart D, Storage and Disposal
Radioactive

waste

PCB waste

Material contaminated with PCBs $>50$ ppm must be stored for disposal (within 1 year) in a facility that is marked for storage and is not located in a 100-year floodplain. The facility should have a roof and walls to prevent rain from reaching the stored PCBs and an impervious floor with $15-\mathrm{cm}$ (6-in.) curbing to provide a double containment volume. Stored articles or containers should be checked monthly for leaks. must be in specified containers in a facility that meets specific design and operational requirements. PCBs can be disposed of only in EPA-approved chemical landfills.
Not an ARAR These requirements are part of an employee protection law (rather than an environmental law) with which CERCLA response actions should comply; hence, they are not subject to the ARAR process. However, they constitute requirements for worker protection with which the proposed action would comply.

Potentially applicable

Potentially applicable $50 \mathrm{ppm}$ are stored temporarily, these requirements would be applicable. PCBs can only be disposed of in an EPA-approved chemical landfill.

Outdoor storage of articles or containers with PCB concentrations in excess of $50 \mathrm{ppm}$ at the temporary storage area will be pursuant to a waiver from the EPA. 
TABLE C.1 (Cont.)

\begin{tabular}{|c|c|c|c|c|}
\hline Citation & Medium & Requirement & $\begin{array}{l}\text { Preliminary } \\
\text { Determination }\end{array}$ & Remarks \\
\hline \multicolumn{5}{|l|}{ Action-Specific ARARs (Cont.) } \\
\hline $\begin{array}{l}\text { Toxic Substances Control Act, as } \\
\text { amended (15 USC 2607-2629; seq. } \\
\text { PL 94-499, et seq.); Polychlorinated } \\
\text { Biphenyls (PCBs) Manufacturing, } \\
\text { Processing, Distribution in Commerce, } \\
\text { and Use Prohibitions (40 CFR Part 761), } \\
\text { Subpart D, Storage and Disposal }\end{array}$ & PCB waste & $\begin{array}{l}\text { Material contaminated with PCBs }>50 \text { ppm must be } \\
\text { incinerated or disposed of in a chemical waste landfill. } \\
\text { Nonliquid material with }>50 \mathrm{ppm} \text { PCBs (e.g., } \\
\text { contaminated soil, rags, or other debris) should be } \\
\text { disposed of by incinerating (or using an alternative } \\
\text { treatment) or landfilling. The chemical waste landfill } \\
\text { should be located in an area with an in-place soil } \\
\text { thickness of } 1.2 \mathrm{~m} \text { ( } 4 \mathrm{ft} \text { ) or compacted thickness of } \\
0.91 \mathrm{~m} \text { ( } 3 \mathrm{ft} \text { ) and a soil permeability of } \leq 10^{-7} \mathrm{~cm} / \mathrm{s} \text {, } \\
>30 \% \text { passing through a no. } 200 \text { sieve, a liquid limit } \\
>30 \text {, and a plasticity index }>15 \text {; a synthetic liner can be } \\
\text { used to achieve an equivalent permeability. The landfill } \\
\text { should also contain a leachate collection system, which } \\
\text { can be a simple gravity-flow drainfield, a compound } \\
\text { system (where a double liner is present), or a suction } \\
\text { lysimeter network. The bottom of the landfill should be } \\
\geq 15 \mathrm{~m} \text { ( } 50 \mathrm{ft} \text { ) above the historical high groundwater } \\
\text { table, and the site should not be hydrologically } \\
\text { connected to standing or flowing water. Structures } \\
\text { should be in place to divert runoff from a } 24 \text {-hour, } \\
25 \text {-year storm. If located below the } 100 \text {-year floodwater } \\
\text { elevation, } 0.61 \text {-m ( } 2 \text {-ft) surface water diversion dikes } \\
\text { should surround the landfill. The landfill should be } \\
\text { located in an area of low to moderate relief to minimize } \\
\text { erosion, landslides, and slumping. Surface water and the } \\
\text { leachate collection system should be monitored (monthly } \\
\text { during operations, then twice per year for surface water), } \\
\text { as should groundwater. }\end{array}$ & $\begin{array}{l}\text { Potentially } \\
\text { applicable }\end{array}$ & $\begin{array}{l}\text { All wastes resulting from this removal action will } \\
\text { be temporarily stored on-site prior to disposal in } \\
\text { an on-site disposal cell consistent with the Record } \\
\text { of Decision issued in September } 1993 \text { for the } \\
\text { chemical plant area. The design of this disposal } \\
\text { cell includes provisions consistent with the } \\
\text { requirements identified here. }\end{array}$ \\
\hline
\end{tabular}


TABLE C.1 (Cont.)

Citation

Action-Specific ARARs (Cont.)

Missouri Hazardous Waste Management

Regulations (10 CSR 25-13.010,

Polychlorinated Biphenyls)

Solid Waste Disposal Act, as amended (42 USC 6901 et seq.); Hazardous Wastes (40 CFR Parts 260-268);

Missouri Hazardous Waste Management

Regulations (10 CSR 25-4.260-268)

Occupational Safety and Health

Administration Standards; Occupational

Noise Exposure (29 CFR Part 1910

Noise levels in

air

1910.95)
In addition to compliance with the Toxic Substances

Control Act and its regulations (40 CFR Part 761), in

Missouri PCB-contaminated ( $250 \mathrm{ppm}$ ) soils are

designated as listed hazardous wastes (M009) and must

be packaged, stored, transported below and disposed of

as hazardous wastes, as outlined in the following citation (Missouri 10 CSR 25-4.260-268).

Hazardous waste A solid waste must be characterized to determine if it is a hazardous waste in accordance with methods set forth

in 40 CFR Part 261/10 CSR 25-4.261; it may be

accumulated and stored for less than 90 days in

accordance with regulations in 40 CFR Part 262/10 CSR

25-4.262; it may be stored for more than 90 days in

accordance with regulations in 40 CFR Part 264/10 CSR

25-4.264; and it must be treated before land disposal in

accordance with regulations in 40 CFR Part 268.

permissible occupational exposure level for noise is

$90 \mathrm{dBA}$ (slow response) for an 8-hour day; with

decreasing times of exposure, the levels increase to

$115 \mathrm{dBA}$ per 15-minute day.

Preliminary

Determination

Remarks

Potentially

applicable

applicable

Not an ARAR

The provisions of these standards are not ARARs because these are not environmental regulations; however, such regulations might be pertinent to protection of workers during the proposed action.
These requirements would be applicable to the treatment or storage of site wastes that meet the prerequisites for definition as hazardous waste PCBs (M009).

If the soils and sediments were found to contain hazardous wastes or exhibit a hazardous characteristic, the accumulation, storage, transportation and disposal would have to comply with these regulations. 
TABLE C.1 (Cont.)

\begin{tabular}{|c|c|c|c|c|c|}
\hline Citation & Contaminant & \multicolumn{2}{|l|}{ Requirement } & $\begin{array}{c}\text { Preliminary } \\
\text { Determination }\end{array}$ & Remarks \\
\hline \multicolumn{6}{|l|}{ Action-Specific ARARs (Cont.) } \\
\hline \multirow[t]{5}{*}{$\begin{array}{l}\text { Occupational Safety and Health } \\
\text { Administration Standards, Subpart G; } \\
\text { lonizing Radiation (29 CFR Part 1910, } \\
\text { 1910.96), Subpart Z; Toxic and } \\
\text { Hazardous Substances (29 CFR } \\
\text { 1910.1000) }\end{array}$} & \multirow[t]{5}{*}{ Radiation } & \multirow{2}{*}{\multicolumn{2}{|c|}{$\begin{array}{l}\text { Within a restricted area, airborne radioactive material } \\
\text { (averaged over a } 40 \text {-hour work week of seven } \\
\text { consecutive days) should not exceed } 7 \times 10^{-11} \text { (soluble) } \\
\text { and } 1 \times 10^{-10} \text { (insoluble). (For hours of exposure less } \\
\text { than or greater than } 40 \text {, the limits are proportionately } \\
\text { increased or decreased, respectively.) } \\
\text { The dose per calendar quarter resulting from exposure to } \\
\text { radiation in a restricted area from sources in that area is } \\
\text { limited to the following: }\end{array}$}} & Not an ARAR & $\begin{array}{l}\text { These regulations are not ARARs because they } \\
\text { are not environmental regulations; however, they } \\
\text { might be pertinent to protection of workers during } \\
\text { the proposed action. }\end{array}$ \\
\hline & & & & & \\
\hline & & Part of Body & $\begin{array}{l}\text { Dose } \\
\text { (rem) }\end{array}$ & & \\
\hline & & $\begin{array}{l}\text { Whole body, head and trunk, } \\
\text { active blood-forming organs, } \\
\text { lens of eye, or gonads } \\
\text { Hands and forearms, feet and ankles } \\
\text { Skin of whole body }\end{array}$ & $\begin{array}{r}11 / 4 \\
183 / 4 \\
71 / 2\end{array}$ & & \\
\hline & & \multicolumn{4}{|c|}{$\begin{array}{l}\text { The occupational exposure of an individual younger than } \\
18 \text { is restricted to } 10 \% \text { of these limits; the whole-body } \\
\text { dose to a worker may not exceed } 3 \text { rem in a calendar } \\
\text { quarter and, when added to the cumulative occupational } \\
\text { dose, should not exceed } 5(\mathrm{~N}-18) \text { rem, where } N \text { is the age } \\
\text { of the exposed individual. }\end{array}$} \\
\hline
\end{tabular}


TABLE C.1 (Cont.)

\begin{tabular}{cccc}
\hline & & & \\
Preliminary & & \\
Citation & Contaminant & Requirement & Determination \\
\hline
\end{tabular}

\section{Action-Specific ARARs (Cont.)}

Occupational Safety and Health

Administration Standards, Subpart G;

Ionizing Radiation (29 CFR Part 1910

1910.96), Subpart Z; Toxic and

Occupational exposure to airborne radioactive material should not

exceed the following annual limits on intake (ALI) and derived air

concentrations (DAC) for three retention classes (days [D], weeks

[W], and years [Y]):

1910.1000) (Cont.)

\begin{tabular}{|c|c|c|c|c|}
\hline \multirow[b]{2}{*}{ Radionuclide $^{\mathrm{a}}$} & \multirow[b]{2}{*}{ Class } & \multirow{2}{*}{$\begin{array}{c}\begin{array}{c}\text { Oral } \\
\text { Ingestion }\end{array} \\
\mathrm{ALI} \\
(\mu \mathrm{Ci})\end{array}$} & \multicolumn{2}{|c|}{ Inhalation } \\
\hline & & & $\begin{array}{c}\mathrm{ALI} \\
(\mu \mathrm{Ci})\end{array}$ & $\begin{array}{c}\text { DAC } \\
(\mu \mathrm{Ci} / \mathrm{mL})\end{array}$ \\
\hline Radium-226 & W & $\begin{array}{c}2.0 \\
(5.0)^{\mathrm{a}}\end{array}$ & 0.6 & $3 \times 10^{-10}$ \\
\hline Radium-228 & W & $\begin{array}{c}2.0 \\
(4.0)\end{array}$ & 1.0 & 5.0 \\
\hline Radon- $220^{b}$ & -. & -- & 20,000 & $7 \times 10^{-6}$ \\
\hline Radon- $220^{c}$ & .. & $\ldots$ & 20 & $9 \times 10^{-9}$ \\
\hline Radon-222 ${ }^{\mathrm{b}}$ & -- & -- & 10,000 & $4 \times 10^{-6}$ \\
\hline Radon- $222^{c}$ & -. & -- & 100 & $3 \times 10^{-8}$ \\
\hline \multirow[t]{2}{*}{ Thorium-230 } & w & $\begin{array}{c}4.0 \\
(9.0)\end{array}$ & $\begin{array}{l}0.006 \\
(0.02)\end{array}$ & $3 \times 10^{-12}$ \\
\hline & $\mathbf{Y}$ & -. & $\begin{array}{c}0.02 \\
(0.02)\end{array}$ & $6 \times 10^{-12}$ \\
\hline \multirow[t]{2}{*}{ Thorium-232 } & $w$ & $\begin{array}{c}0.7 \\
(2.0)\end{array}$ & $\begin{array}{c}0.001 \\
(0.003)\end{array}$ & $5 \times 10^{-13}$ \\
\hline & $Y$ & -. & $\begin{array}{c}0.003 \\
(0.004)\end{array}$ & $1 \times 10^{-12}$ \\
\hline
\end{tabular}

a Values in parentheses are for bone surfaces.

b With decay products removed.

c With decay products present. 
TABLE C.1 (Cont.)

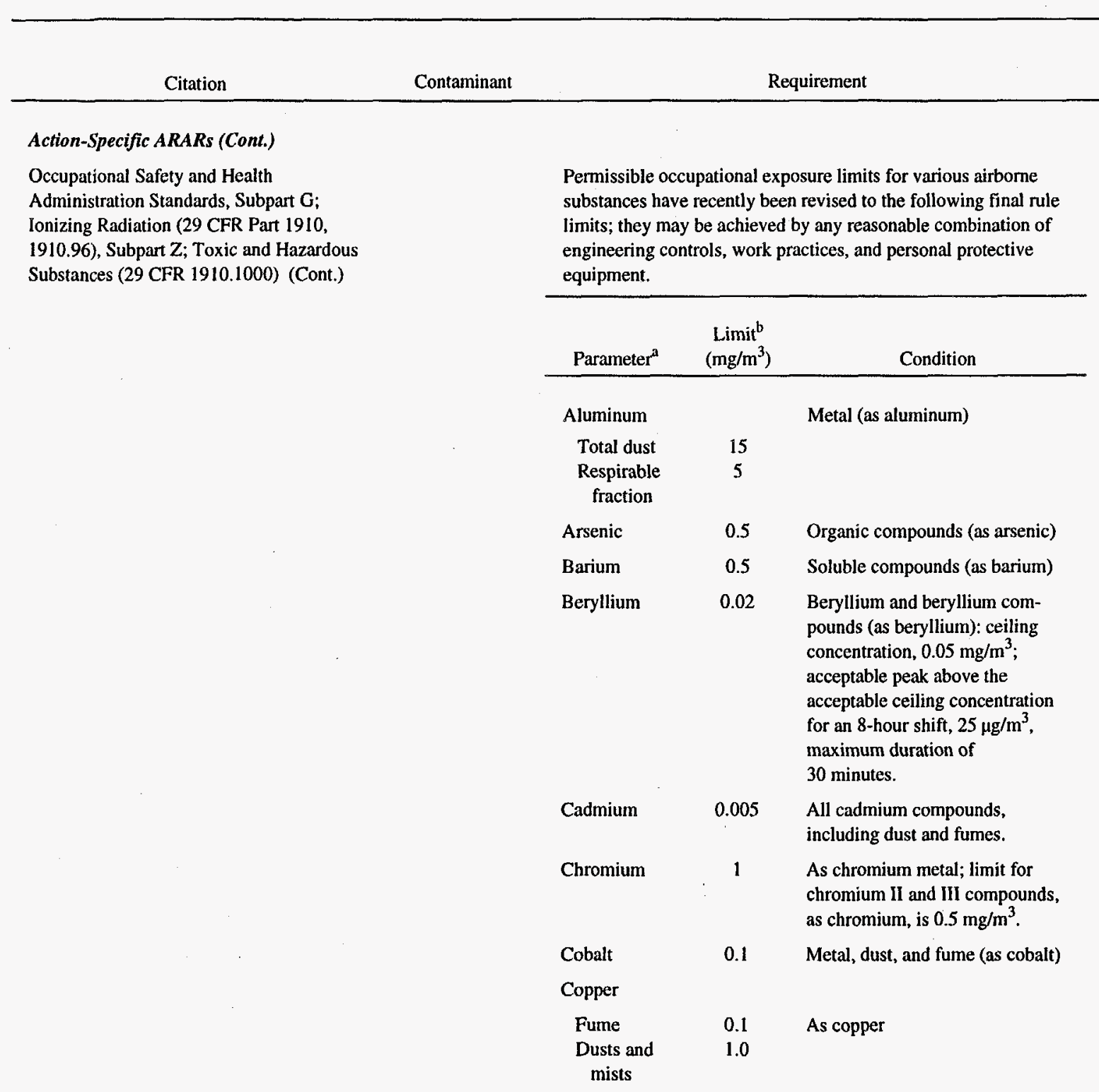

Action-Specific ARARs (Cont.)

Occupational Safety and Health

1910.96), Subpart Z Toxic and Hazardous

Substances (29 CFR 1910.1000) (Cont.)
Permissible occupational exposure limits for various airborne

ine recently been revised to the following hnal rule

equipmen 
TABLE C.1 (Cont.)

\begin{tabular}{|c|c|c|c|c|}
\hline Citation & Contaminant & \multicolumn{3}{|c|}{ Requirement } \\
\hline \multirow{11}{*}{$\begin{array}{l}\text { Occupational Safety and Health } \\
\text { Administration Standards, Subpart G; } \\
\text { Ionizing Radiation ( } 29 \text { CFR Part } 1910 \text {, } \\
\text { 1910.96), Subpart Z; Toxic and Hazardous } \\
\text { Substances (29 CFR 1910.1000) (Cont.) }\end{array}$} & & Parameter & $\underset{\left(m g / m^{3}\right)}{\mathrm{Limit}^{\mathrm{b}}}$ & Condition \\
\hline & & Lead & 0.05 & $\begin{array}{l}\text { For metallic lead and inorganic } \\
\text { compounds, as lead. }\end{array}$ \\
\hline & & $\begin{array}{l}\text { Manganese } \\
\text { compounds }\end{array}$ & 5 & Ceiling limit (as manganese) \\
\hline & & Fume & 5 & Ceiling limit (as manganese) \\
\hline & & Mercury & $\begin{array}{l}1 \mathrm{mg} / \\
10 \mathrm{~m}^{3}\end{array}$ & Ceiling limit \\
\hline & & Nickel & 1.0 & $\begin{array}{l}\text { For soluble compounds, as } \\
\text { nickel; for metallic nickel and } \\
\text { insoluble compounds, as nickel. }\end{array}$ \\
\hline & & PCBs & 1.0 & $\begin{array}{l}\text { As chlorodiphenyl ( } 42 \% \\
\text { chlorine) }\end{array}$ \\
\hline & & & 0.5 & $\begin{array}{l}\text { As chlorodiphenyl ( } 54 \% \\
\text { chlorine) }\end{array}$ \\
\hline & & Selenium & 0.2 & Compounds (as selenium) \\
\hline & & Uranium & 0.05 & $\begin{array}{l}\text { For soluble compounds, as } \\
\text { uranium; for insoluble } \\
\text { compounds, as uranium. }\end{array}$ \\
\hline & & $\begin{array}{c}\text { Particulates } \\
\text { Total dust } \\
\text { Respirable } \\
\text { fraction }\end{array}$ & $\begin{array}{l}50 \\
15\end{array}$ & $\begin{array}{l}\text { For particulates not otherwise } \\
\text { regulated (i.e., nuisance dust). }\end{array}$ \\
\hline
\end{tabular}

Preliminary

Determination

Remarks

ministration Standards, Subpart

Adining Radiation (29 CFR Part 1910

1910.96), Subpart Z; Toxic and Hazardous

Substances (29 CFR 1910.1000) (Cont)

fraction 
TABLE C.1 (Cont.)

\begin{tabular}{|c|c|c|c|c|}
\hline Citation & Contaminant & \multicolumn{3}{|c|}{ Requirement } \\
\hline \multicolumn{5}{|l|}{ Action-Specific ARARs (Cont.) } \\
\hline \multirow{2}{*}{$\begin{array}{l}\text { Occupational Safety and Health } \\
\text { Administration Standards, Subpart G; } \\
\text { Ionizing Radiation ( } 29 \text { CFR Part 1910, } \\
\text { 1910.96), Subpart Z; Toxic and Hazardous } \\
\text { Substances (29 CFR 1910.1000) (Cont.) }\end{array}$} & & Parameter & $\underset{\left(\mathrm{mg} / \mathrm{m}^{3}\right)}{\text { Limit }^{\mathrm{b}}}$ & Condition \\
\hline & & DNB & 1 & For all DNB isomers ${ }^{\mathrm{e}}$ \\
\hline \multirow[t]{4}{*}{. } & & 2,4-DNT & 1.5 & $\begin{array}{l}\text { For total DNT; isomer } \\
\text { unspecified }^{\mathbf{c}}\end{array}$ \\
\hline & & 2,6-DNT & 1.5 & $\begin{array}{l}\text { For total DNT; isomer } \\
\text { unspecified }^{\mathbf{c}}\end{array}$ \\
\hline & & NB & 5 & See footnote $\mathrm{c}$ \\
\hline & & TNT & 1.5 & See footnote $\mathrm{c}$ \\
\hline
\end{tabular}

a Notation: DNB, dinitrobenzene; 2,4-DNT, 2,4-dinitrotoluene; 2,6-DNT, 2,6-dinitrotoluene; NB, nitrobenzene; TNB, trinitrobenzene; TNT, trinitrotoluene; PCBs, polychlorinated

Preliminary Determination Remarks

$$
\text { biphenyls. }
$$

b Permissible exposure limit (PEL) expressed as the 8-hour time-weighted average, except as noted.

c Skin adsorption to be reduced (e.g., with protective clothing) to limit overall exposure via the cutaneous route (airborne or direct contact).

Occupational exposure to general employees resulting from DOE activities (other than planned special exposures and emergency exposure situations) shall not exceed the following:

(1) Total effective dose equivalent, $5 \mathrm{rem}$;

(2) Sum of the deep dose equivalent for external exposures and the committed dose equivalent to any organ or tissue other than the lens of the eye, 50 rem;

(3) Dose equivalent to the lens of the eye, $15 \mathrm{rem}$; and

(4) Shallow dose equivalent to the skin or to any extremity, $50 \mathrm{rem}$.

Not an ARAR

regulations are not ARARs because they are not environmental regulations; however, they might be pertinent to protection of workers during the proposed action. 
TABLE C.1 (Cont.)

\begin{tabular}{|c|c|c|c|c|c|c|c|}
\hline Citation & Contaminant & \multicolumn{4}{|c|}{ Requirement } & $\begin{array}{l}\text { Preliminary } \\
\text { Determination }\end{array}$ & Remarks \\
\hline \multirow[t]{5}{*}{$\begin{array}{l}\text { Occupational Radiation Protection } \\
\text { (10 CFR Part 835) }\end{array}$} & \multirow[t]{5}{*}{$\begin{array}{l}\text { Specific radio- } \\
\text { nuclides (see } \\
\text { table) in air }\end{array}$} & \multicolumn{4}{|c|}{$\begin{array}{l}\text { The derived air concentrations (DAC) for limiting radiation } \\
\text { exposures through inhalation by workers for three retention } \\
\text { classes }(\mathrm{D}, \mathrm{W} \text {, and } \mathrm{Y}) \text { are as follows: }\end{array}$} & Not an ARAR & $\begin{array}{l}\text { These requirements are not } \\
\text { environmental regulations; however, } \\
\text { they might be pertinent to worker }\end{array}$ \\
\hline & & & \multicolumn{3}{|c|}{$\mathrm{DAC}(\mu \mathrm{Ci} / \mathrm{mL})$} & & \\
\hline & & Radionuclide & $\begin{array}{c}\text { Class } \\
\text { D }\end{array}$ & $\begin{array}{c}\text { Class } \\
W\end{array}$ & $\begin{array}{c}\text { Class } \\
\mathbf{Y}\end{array}$ & & \\
\hline & & $\begin{array}{l}\text { Radium-226 } \\
\text { Radium-228 } \\
\text { Radon-222 } \\
\text { Thorium-230 } \\
\text { Thorium-232 } \\
\text { Uranium-235 } \\
\text { Uranium-238 }\end{array}$ & $\begin{array}{c}- \\
- \\
3 \times 10^{-8} \\
- \\
\cdot \\
6 \times 10^{-10} \\
6 \times 10^{-10}\end{array}$ & $\begin{array}{c}3 \times 10^{-10} \\
5 \times 10^{-10} \\
- \\
3 \times 10^{-12} \\
5 \times 10^{-12} \\
3 \times 10^{-10} \\
3 \times 10^{-10}\end{array}$ & $\begin{array}{c}- \\
- \\
- \\
7 \times 10^{-12} \\
1 \times 10^{-12} \\
2 \times 10^{-11} \\
2 \times 10^{-11}\end{array}$ & & \\
\hline & & $\begin{array}{l}\text { For radon } \\
\text { products; } \\
\text { conditions }\end{array}$ & $\begin{array}{l}\text { mbined wit } \\
100 \% \text { equi } \\
\text { the decay }\end{array}$ & $\begin{array}{l}\text { s short-live } \\
\text { ium conce } \\
\text { ducts. }\end{array}$ & $\begin{array}{l}\text { decay } \\
\text { ation }\end{array}$ & & \\
\hline
\end{tabular}


TABLE C.1 (Cont.)

\begin{tabular}{|c|c|c|c|c|c|c|}
\hline Citation & Contaminant & \multicolumn{3}{|c|}{ Requirement } & $\begin{array}{c}\text { Preliminary } \\
\text { Determination }\end{array}$ & Remarks \\
\hline \multicolumn{7}{|l|}{ Action-Specific ARARs (Cont.) } \\
\hline \multirow{6}{*}{$\begin{array}{l}\text { Missouri Radiation Regulations; Protection } \\
\text { against Ionizing Radiation (19 CSR 20- } \\
\text { 10.040), Maximum Permissible Exposure } \\
\text { Limits }\end{array}$} & \multirow[t]{6}{*}{ Radiation } & \multicolumn{3}{|c|}{$\begin{array}{l}\text { Limits for occupational doses from ionizing radiation in a } \\
\text { controlled area are as follows: }\end{array}$} & \multirow[t]{6}{*}{ Not an ARAR } & \multirow{6}{*}{$\begin{array}{l}\text { These requirements are part of an } \\
\text { employee protection law (rather than } \\
\text { an environmental law) with which } \\
\text { CERCLA response actions should } \\
\text { comply; hence, they are not subject to } \\
\text { the ARAR process. They are indicated } \\
\text { in this table to identify requirements } \\
\text { for worker protection with which the } \\
\text { remedial action would comply. }\end{array}$} \\
\hline & & Part of Body & $\begin{array}{l}\text { Maximum Dose } \\
\text { in Any } \\
\text { Calendar Year } \\
\text { (rem) }\end{array}$ & $\begin{array}{l}\text { Maximum Dose } \\
\text { in Any } \\
\text { Calendar Quarter } \\
\quad(\mathrm{rem})\end{array}$ & & \\
\hline & & $\begin{array}{l}\text { Whole body, } \\
\text { head and trunk, } \\
\text { major portion of } \\
\text { bone marrow, } \\
\text { gonads, or } \\
\text { lens of eye }\end{array}$ & f & 3 & & \\
\hline & & $\begin{array}{l}\text { Hands and fore- } \\
\text { arms, feet and } \\
\text { ankles }\end{array}$ & 75 & 25 & & \\
\hline & & $\begin{array}{l}\text { Skin of large } \\
\text { body area }\end{array}$ & 30 & 10 & & \\
\hline & & \multicolumn{3}{|c|}{$\begin{array}{l}\text { Also, the whole-body dose added to the cumulative } \\
\text { occupational dose should not exceed } 5(\mathrm{~N}-18) \text { rem, } \\
\text { where } N \text { is the age of the exposed individual. }\end{array}$} & & \\
\hline
\end{tabular}


TABLE C.1 (Cont.)

\begin{tabular}{cccc}
\hline & & & \\
Preliminary & & & \\
Determination & Requirement & Remarks & Contaminant \\
\hline
\end{tabular}

Action-Specific ARARs (Cont.)

Missouri Radiation Regulations; Protection Radiation against Ionizing Radiation (19 CSR 20-

10.050), Personnel Monitoring and

Radiation Surveys

Missouri Radiation Regulations; Protection against Ionizing Radiation (19 CSR 20-

10.040), Maximum Permissible Exposure

Limits
Personnel monitoring and radiation surveys are required for each worker for whom there is any reasonable possibility of receivin a weekly dose from all radiation exceeding $50 \mathrm{mrem}$, taking into consideration the use of protective gloves and radiation-limiting devices. An exemption from routine monitoring may be granted under certain conditions. nuclides in air

The concentrations above natural background of radionuclides in air outside a controlled area, averaged over any calendar quarter, should not exceed the following limits:

\begin{tabular}{lcc}
\hline & \multicolumn{2}{c}{$\begin{array}{c}\text { Concentration Limit } \\
(\mu \mathrm{Ci} / \mathrm{mL})\end{array}$} \\
\cline { 2 - 3 } Isotope & Soluble & Insoluble \\
\hline Radium-226 & $1 \times 10^{-12}$ & $6 \times 10^{-9}$ \\
Radium-228 & $2 \times 10^{-12}$ & $1 \times 10^{-12}$ \\
Radon-222 & $1 \times 10^{-9}$ & $\mathrm{NA}^{\mathrm{a}}$ \\
Thorium-230 & $8 \times 10^{-14}$ & $3 \times 10^{-13}$ \\
Thorium-232 & $7 \times 10^{-14}$ & $4 \times 10^{-13}$ \\
Uranium-235 & $2 \times 10^{-11}$ & $4 \times 10^{-12}$ \\
Uranium-238 & $3 \times 10^{-12}$ & $5 \times 10^{-12}$ \\
\hline
\end{tabular}

a Not applicable because radon-222 is a gas.
Not an ARAR

These requirements are part of an employee protection law (rather tha an environmental law) with which CERCLA response actions should comply; hence, they are not subject to the ARAR process. They are indicated in this table to identify requirements for worker protection with which the remedial action would comply.

Potentially applicable

\section{These requirements would be}

applicable to protection of the public

during implementation of the remedial action. 
TABLE C.1 (Cont.)

\begin{tabular}{|c|c|c|c|c|c|c|}
\hline Citation & Contaminant & \multicolumn{3}{|c|}{ Requirement } & $\begin{array}{l}\text { Preliminary } \\
\text { Determination }\end{array}$ & Remarks \\
\hline \multicolumn{7}{|l|}{ Action-Specific ARARs (Cont.) } \\
\hline \multirow{11}{*}{$\begin{array}{l}\text { Missouri Radiation Regulations; Protection } \\
\text { against Ionizing Radiation (19 CSR 20- } \\
\text { 10.040), Maximum Permissible Exposure } \\
\text { Limits }\end{array}$} & \multirow[t]{10}{*}{$\begin{array}{l}\text { Specific radio- } \\
\text { nuclides in air }\end{array}$} & \multicolumn{3}{|c|}{$\begin{array}{l}\text { Occupational exposure to airborne radioactive material, averaged } \\
\text { over any calendar quarter, should not exceed the following } \\
\text { limits: }\end{array}$} & \multirow[t]{10}{*}{ Not an ARAR } & \multirow{10}{*}{$\begin{array}{l}\text { These requirements are part of an } \\
\text { employee protection law (rather than } \\
\text { an environmental law) with which } \\
\text { CERCLA response actions should } \\
\text { comply; hence, they are not subject to } \\
\text { the ARAR process. They are indicated } \\
\text { in this table to identify requirements } \\
\text { for worker protection with which the } \\
\text { remedial action would comply. }\end{array}$} \\
\hline & & & \multicolumn{2}{|c|}{$\begin{array}{c}\text { Concentration Limit } \\
(\mu \mathrm{Ci} / \mathrm{mL})\end{array}$} & & \\
\hline & & Isotope & Soluble & Insoluble & & \\
\hline & & Radium-226 & $3 \times 10^{-11}$ & $2 \times 10^{-7}$ & & \\
\hline & & Radium-228 & $7 \times 10^{-11}$ & $4 \times 10^{-11}$ & & \\
\hline & & Radon-222 & $3 \times 10^{-8}$ & $\mathrm{NA}^{\mathrm{a}}$ & & \\
\hline & & Thorium-230 & $2 \times 10^{-12}$ & $1 \times 10^{-11}$ & & \\
\hline & & Thorium-232 & $2 \times 10^{-12}$ & $1 \times 10^{-11}$ & & \\
\hline & & Uranium-235 & $5 \times 10^{-10}$ & $1 \times 10^{-10}$ & & \\
\hline & & Uranium-238 & $7 \times 10^{-11}$ & $1 \times 10^{-10}$ & & \\
\hline & & a Not applic & use radon- & 2 is a gas. & & \\
\hline
\end{tabular}

